Prepared in cooperation with the Alabama Department of Transportation

\title{
Effects of Culvert Construction on Streams and Macroinvertebrate Communities at Selected Sites in the East Gulf Coastal Plain of Alabama, 2010-19
}

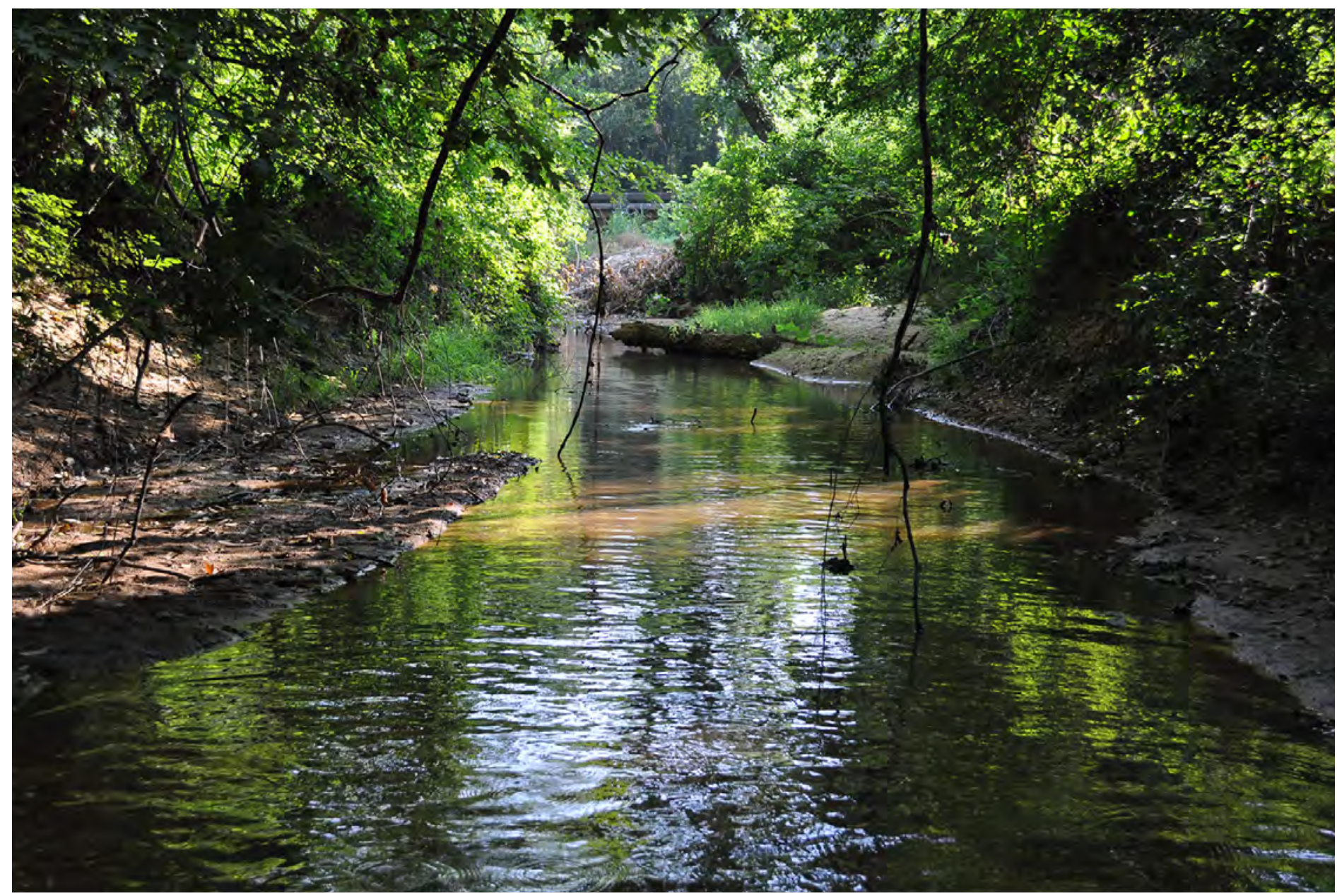

Scientific Investigations Report 2021-5096 
Cover: Oakmulgee Creek near Lawley, Alabama, looking upstream with the U.S. Highway 82 bridge in the background. Photograph by Amy Gill, U.S. Geological Survey, June 14, 2011. 


\section{Effects of Culvert Construction on Streams and Macroinvertebrate Communities at Selected Sites in the East Gulf Coastal Plain of Alabama, 2010-19}

By Aaron L. Pugh and Amy C. Gill

Prepared in cooperation with the Alabama Department of Transportation

Scientific Investigations Report 2021-5096 


\section{U.S. Geological Survey, Reston, Virginia: 2021}

For more information on the USGS - the Federal source for science about the Earth, its natural and living resources, natural hazards, and the environment—visit https://www.usgs.gov or call 1-888-ASK-USGS.

For an overview of USGS information products, including maps, imagery, and publications, visit https://store.usgs.gov/.

Any use of trade, firm, or product names is for descriptive purposes only and does not imply endorsement by the U.S. Government.

Although this information product, for the most part, is in the public domain, it also may contain copyrighted materials as noted in the text. Permission to reproduce copyrighted items must be secured from the copyright owner.

Suggested citation:

Pugh, A.L., and Gill, A.C., 2021, Effects of culvert construction on streams and macroinvertebrate communities at selected sites in the East Gulf Coastal Plain of Alabama, 2010-19: U.S. Geological Survey Scientific Investigations Report 2021-5096, 52 p., https://doi.org/10.3133/sir20215096.

Associated data for this publication:

Gill, A.C., and Pugh, A.L., 2021, Aerial imagery, benthic macroinvertebrate, topographic survey, and soil survey datasets collected for a study of effects of culverts on the natural conditions of streams in the East Gulf Coastal Plain of Alabama, 2010-2019: U.S. Geological Survey data release, https://doi.org/10.5066/P906BOVO.

U.S. Geological Survey, 2020, USGS water data for the Nation: U.S. Geological Survey National Water Information System database, https://doi.org/10.5066/F7P55KJN.

ISSN 2328-0328 (online) 


\section{Contents}

Abstract

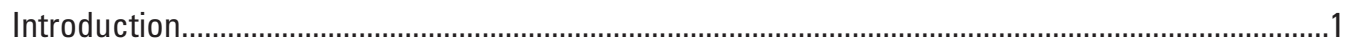

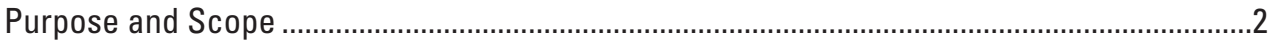

General Study Site Description ........................................................................................

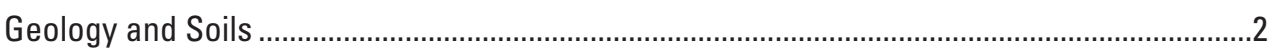

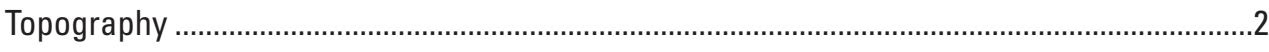

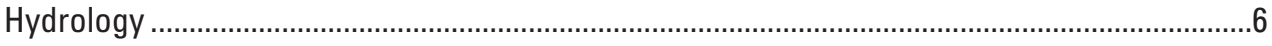

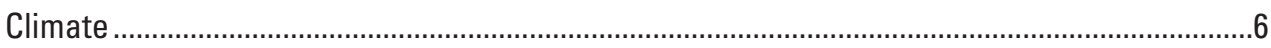

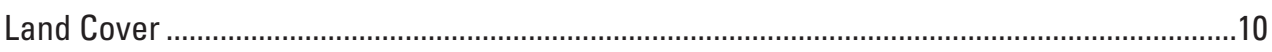

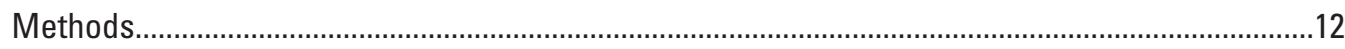

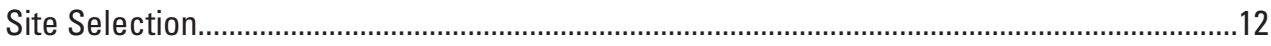

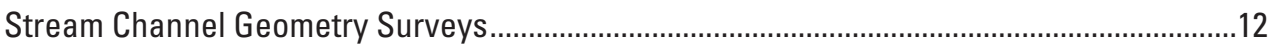

Suspended Sediment and Turbidity Sampling .....................................................................12

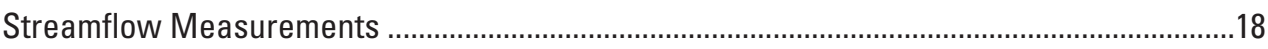

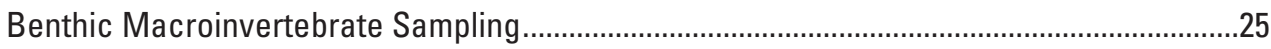

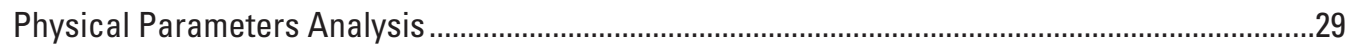

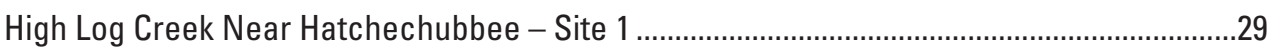

Stream Channel Geometry ....................................................................................29

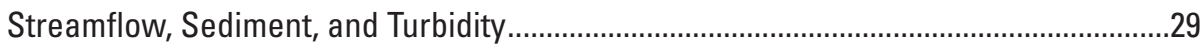

Tributary to Cahaba River Near Centreville - Site 2 ..........................................................29

Stream Channel Geometry ...................................................................................29

Streamflow, Sediment, and Turbidity.........................................................................32

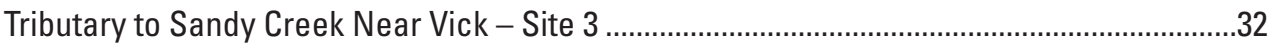

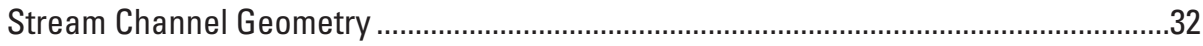

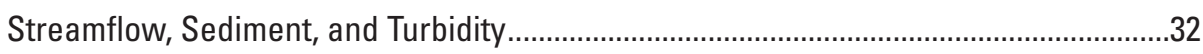

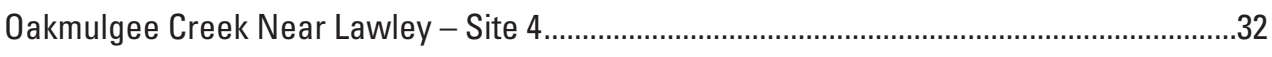

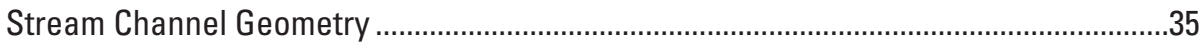

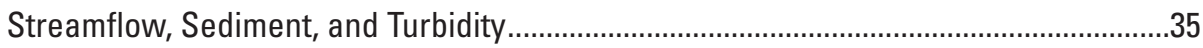

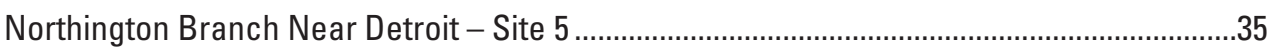

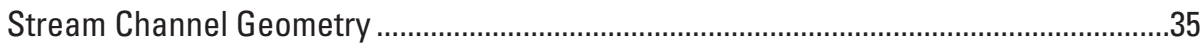

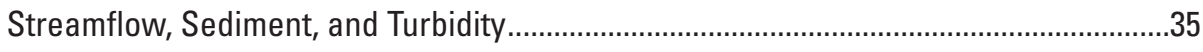

Lye Branch Near Duncanville - Site 6.................................................................................

Stream Channel Geometry ....................................................................................38

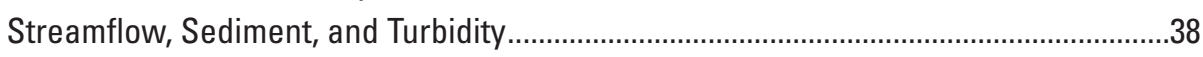

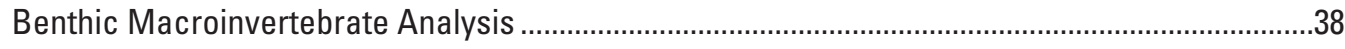

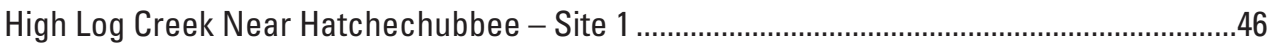

Tributary to Cahaba River Near Centreville - Site 2 2...............................................................46

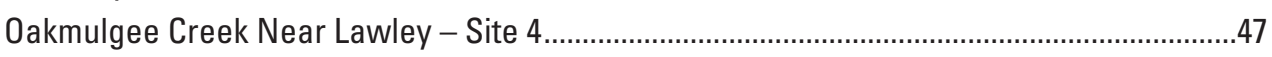

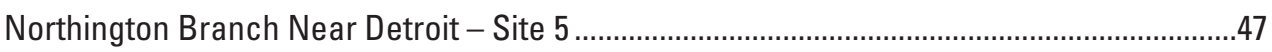

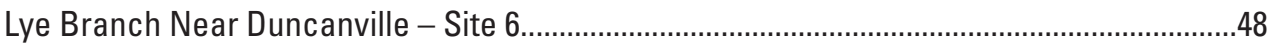

Limitations of This Study and Lessons Learned ........................................................................

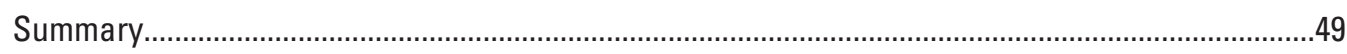

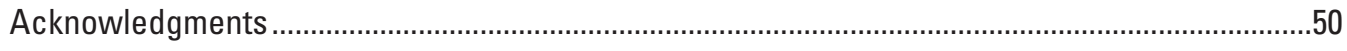

References 


\section{Figures}

1. Map showing locations of sites used in the culvert study and Physiographic Sections of Alabama...

2. Map showing locations of sites used in the culvert study and generalized surficial geology of Alabama...

3. Map showing locations of sites used in the culvert study and hydrologic subregions of Alabama

4. Longitudinal profiles of before- and after-construction thalwegs, upstream and downstream of selected study sites in Alabama

5. Map showing the location of High Log Creek near Hatchechubbee (site 1) and the associated drainage area.

6. Map showing the location of Tributary to Cahaba River near Centreville (site 2) and the associated drainage area.

7. Map showing the location of Tributary to Sandy Creek near Vick (site 3) and the associated drainage area

8. Map showing the location of Oakmulgee Creek near Lawley (site 4) and the associated drainage area.

9. Map showing the location of Northington Branch near Detroit (site 5) and the associated drainage area

10. Map showing the location of Lye Branch near Duncanville (site 6) and the associated drainage area

11. Graphs showing total abundance of benthic macroinvertebrates, abundance of Ephemeroptera, Plecoptera, and Trichoptera (EPT) organisms, and EPT abundance as a percentage of total abundance in before-, during-, and after-construction samples collected from reaches upstream and downstream of new culvert installations at selected sites in Alabama

12. Graphs showing total taxa richness, Ephemeroptera, Plecoptera, and Trichoptera (EPT) taxa richness, and EPT richness as a percentage of total richness in before-, during-, and after-construction samples collected from reaches upstream and downstream of new culvert installations at selected sites in Alabama.

13. Graphs showing average community tolerance values based on total abundance and taxa richness in benthic macroinvertebrate community samples collected at selected culvert installation sites in Alabama

14. Bland-Altman plots showing differences in total abundance and Ephemeroptera, Plecoptera, and Trichoptera abundance in benthic macroinvertebrate samples collected before, during, and after culvert installation from upstream and downstream of selected culverts in Alabama

15. Bland-Altman plots showing differences in total richness and Ephemeroptera, Plecoptera, and Trichoptera richness in benthic macroinvertebrate samples collected before, during, and after culvert installation from upstream and downstream of selected culverts in Alabama

16. Bland-Altman plots showing differences in abundance-weighted tolerance values and richness-based tolerance values for samples collected before, during, and after culvert construction from upstream and downstream of selected culverts in Alabama 


\section{Tables}

1. Site numbers and names with associated USGS streamgage stations, drainage area, locations, and stream order information

2. Alabama Department of Transportation construction information for culverts at six sites in Alabama.

3. Surficial geology mapped within selected stream reach drainage basins in Alabama .6

4. Soil series mapped within selected stream reach drainage basins in Alabama ..............8

5. Hydrologic units in which selected study sites are located in Alabama ............................8

6. Estimates of peak streamflow from regional regression relations at six study sites in Alabama..

7. Land cover within the drainage basins above the selected study sites in Alabama ......11

8. Land cover class descriptions associated within the drainage basins above the selected study sites in Alabama

9. Results of paired sample t-tests of mean area, width, and depth at cross sections to determine significant differences between the before- and after-construction parameters at selected study sites in Alabama

10. Results of paired sample t-tests to determine the difference between the before- and after-construction thalweg slopes at selected study sites in Alabama ......15

11. Ratios of paired upstream to downstream suspended sediment concentrations and turbidity values collected during storm events measured before, during, and after construction at selected study sites in Alabama

12. Analysis of ratios of paired upstream to downstream suspended sediment concentrations and turbidity values measured before, during, and after construction at selected study sites in Alabama

13. Storm events and maximum measured streamflow at selected study sites in Alabama

14. Sampled instream habitats and after-construction water-quality field parameters at selected new culvert installation sites, Alabama

15. Habitat parameters and scores for condition category.

16. Habitat scores for each reach at selected sites sampled for benthic macroinvertebrate communities, Alabama

17. Metrics calculated by IDAS and Wilcoxon rank sum statistics to test for significance of differences between before-construction and after-construction variation for metric values in upstream and downstream reaches at selected sites in Alabama. 


\section{Conversion Factors}

U.S. customary units to International System of Units

\begin{tabular}{|c|c|c|}
\hline Multiply & By & To obtain \\
\hline \multicolumn{3}{|c|}{ Length } \\
\hline inch (in.) & 2.54 & centimeter $(\mathrm{cm})$ \\
\hline inch (in.) & 25.4 & millimeter (mm) \\
\hline foot (ft) & 0.3048 & meter $(\mathrm{m})$ \\
\hline mile (mi) & 1.609 & kilometer $(\mathrm{km})$ \\
\hline \multicolumn{3}{|c|}{ Area } \\
\hline acre & 4,047 & square meter $\left(\mathrm{m}^{2}\right)$ \\
\hline acre & 0.4047 & hectare (ha) \\
\hline acre & 0.4047 & square hectometer $\left(\mathrm{hm}^{2}\right)$ \\
\hline acre & 0.004047 & square kilometer $\left(\mathrm{km}^{2}\right)$ \\
\hline square mile $\left(\mathrm{mi}^{2}\right)$ & 259.0 & hectare (ha) \\
\hline square mile $\left(\mathrm{mi}^{2}\right)$ & 2.590 & square kilometer $\left(\mathrm{km}^{2}\right)$ \\
\hline \multicolumn{3}{|c|}{ Volume } \\
\hline ounce, fluid (fl. oz) & 0.02957 & liter (L) \\
\hline $\operatorname{pint}(\mathrm{pt})$ & 0.4732 & liter $(\mathrm{L})$ \\
\hline quart (qt) & 0.9464 & liter $(\mathrm{L})$ \\
\hline gallon (gal) & 3.785 & liter $(\mathrm{L})$ \\
\hline \multicolumn{3}{|c|}{ Flow rate } \\
\hline cubic foot per second $\left(\mathrm{ft}^{3} / \mathrm{s}\right)$ & 0.02832 & cubic meter per second $\left(\mathrm{m}^{3} / \mathrm{s}\right)$ \\
\hline \multicolumn{3}{|c|}{ Hydraulic gradient } \\
\hline foot per mile (ft/mi) & 0.3048 & meter per day $(\mathrm{m} / \mathrm{d})$ \\
\hline
\end{tabular}

International System of Units to U.S. customary units

\begin{tabular}{|c|c|c|}
\hline Multiply & By & To obtain \\
\hline \multicolumn{3}{|c|}{ Length } \\
\hline meter (m) & 3.281 & foot $(\mathrm{ft})$ \\
\hline kilometer (km) & 0.6214 & mile (mi) \\
\hline kilometer (km) & 0.5400 & mile, nautical (nmi) \\
\hline meter $(\mathrm{m})$ & 1.094 & yard (yd) \\
\hline \multicolumn{3}{|c|}{ Area } \\
\hline square meter $\left(\mathrm{m}^{2}\right)$ & 10.76 & square foot $\left(\mathrm{ft}^{2}\right)$ \\
\hline square kilometer $\left(\mathrm{km}^{2}\right)$ & 0.3861 & square mile $\left(\mathrm{mi}^{2}\right)$ \\
\hline \multicolumn{3}{|c|}{ Volume } \\
\hline liter $(\mathrm{L})$ & 0.2642 & gallon (gal) \\
\hline \multicolumn{3}{|c|}{ Flow rate } \\
\hline cubic meter per second $\left(\mathrm{m}^{3} / \mathrm{s}\right)$ & 35.31 & cubic foot per second $\left(\mathrm{ft}^{3} / \mathrm{s}\right)$ \\
\hline
\end{tabular}

Temperature in degrees Celsius $\left({ }^{\circ} \mathrm{C}\right)$ may be converted to degrees Fahrenheit $\left({ }^{\circ} \mathrm{F}\right)$ as ${ }^{\circ} \mathrm{F}=(1.8 \times$ $\left.{ }^{\circ} \mathrm{C}\right)+32$.

Temperature in degrees Fahrenheit $\left({ }^{\circ} \mathrm{F}\right)$ may be converted to degrees Celsius $\left({ }^{\circ} \mathrm{C}\right)$ as ${ }^{\circ} \mathrm{C}=\left({ }^{\circ} \mathrm{F}-\right.$ 32) / 1.8 . 


\section{Datum}

Vertical coordinate information is referenced to the North American Vertical Datum of 1988 (NAVD 88).

Horizontal coordinate information is referenced to the North American Datum of 1927 (NAD 27).

Elevation, as used in this report, refers to distance above the vertical datum.

\section{Supplemental Information}

Specific conductance is given in microsiemens per centimeter at 25 degrees Celsius $(\mu \mathrm{S} / \mathrm{cm}$ at $\left.25^{\circ} \mathrm{C}\right)$.

Concentrations of constituents in water are given in milligrams per liter (mg/L).

Turbidity is the measure of relative clarity of a liquid and is measured in Nephelometric Turbidity Ratio Units (NTRU).

\section{Abbreviations}

$\begin{array}{ll}\text { ADEM } & \text { Alabama Department of Environmental Management } \\ \text { ALDOT } & \text { Alabama Department of Transportation } \\ \text { EPA } & \text { U.S. Environmental Protection Agency } \\ \text { EPT } & \text { Ephemeroptera, Plecoptera, and Trichoptera } \\ \text { IDAS } & \text { Invertebrate Data Analysis System } \\ \text { NAWQA } & \text { National Water-Quality Assessment } \\ \text { NWQL } & \text { National Water Quality Laboratory } \\ \text { MA } & \text { mega-annum (1 million years) } \\ \text { TV } & \text { tolerance value } \\ \text { USGS } & \text { U.S. Geological Survey }\end{array}$





\title{
Effects of Culvert Construction on Streams and Macroinvertebrate Communities at Selected Sites in the East Gulf Coastal Plain of Alabama, 2010-19
}

\author{
By Aaron L. Pugh and Amy C. Gill
}

\section{Abstract}

The U.S. Geological Survey, in cooperation with the Alabama Department of Transportation, evaluated the role of culvert construction in altering streams and habitats of benthic macroinvertebrate communities at selected study sites in the northern East Gulf Coastal Plain of Alabama during 2011-19. Analysis included examinations of changes in stream channel geometry, suspended sediment, turbidity, and benthic macroinvertebrate communities.

Topographic surveys of stream channel cross sections, upstream and downstream of the culvert, were conducted before and after construction. Changes in channel geometry (cross-sectional area, top width, mean depth, and thalweg slope) were assessed by using paired sample t-tests to compare before- and after-construction channel geometry measurements. Statistically significant changes in stream channel geometry between the before- and after-construction measurements were observed at four of the six study sites. Analysis of the channel geometry data indicates that 1 site had no measured changes, and thalweg reach slopes were inverted at 4 of the 12 study reaches -2 measured in before-construction reaches and 2 measured in after-construction reaches.

Surface-water samples were collected during selected storm events for suspended sediment and turbidity analyses. Samples were simultaneously collected upstream and downstream of the culvert construction reaches during all three phases of construction (before, during, and after). Analysis focused on the parity of upstream to downstream simultaneous samples. The mean upstream to downstream paired ratios of sediment concentrations and turbidity from the afterconstruction phase indicate that colloidal and noncolloidal sediments were passing through the construction reaches at two of the six sites, noncolloidal sediments were being trapped in the construction reaches at two sites, and colloidal and noncolloidal sediments were being removed from the construction reach at two sites.

Benthic macroinvertebrates were collected and identified at five of the six sites from instream habitats that were available in sampled areas both upstream and downstream of the culvert construction reaches. Differences between upstream and downstream reaches and the Wilcoxon rank sum statistic were used to examine changes in metrics of benthic macroinvertebrate communities between before- and after-construction phases. Benthic macroinvertebrate sampling results did not indicate that culvert construction caused impairment to communities at study sites. No tolerance metrics suggested a major change in the pollution tolerance of the communities. The same upstream to downstream patterns in abundanceweighted tolerance values were observed in the before- and after-construction periods at each site. At one site, the difference between upstream and downstream richness-based tolerance values increased, but the after-construction upstream and downstream richness-based tolerance values were lower (indicating a less pollution-tolerant macroinvertebrate community) than in the before-construction period.

\section{Introduction}

Physical characteristics of streams change during humanengineered modifications of stream channels (Lynch and others, 1977; Hahn, 1982; Brookes, 1988; Bolton and Shellberg, 2001; Jackson, 2003; Johansen, 2003). Reported changes include water temperature, turbidity, flow velocities, channel geometry, hydraulic flow regime, the amount and type of vegetation, the storage of organic matter, and the amount, size, and stability of suspended sediment and channel substrate.

The physical characteristics of streams form the habitat that aquatic biota require to thrive. Aquatic biota community growth, abundance, reproduction, and survival can change when physical stream characteristics change. The degree to which an aquatic community is affected, however, can vary with the type of channel modification and site characteristics.

The U.S. Geological Survey (USGS), in cooperation with the Alabama Department of Transportation (ALDOT), conducted a three-phase (before, during, and after construction) scientific assessment, over 10 years, to evaluate culvert effects on channel geometry, sediment concentration, turbidity, and benthic macroinvertebrate communities. Monitoring changes in channel geometry and sediment related to culvert installations can help to determine if stream conditions are stable 
or if improvements to culvert designs are needed to support biotic communities after construction. The results of this study can be used by transportation managers to inform design of future culvert road crossings of streams. This work supports a major goal of the USGS Water Mission Area Science Strategy (Evenson and others, 2013) to "advance understanding of processes that determine water availability." The sampling and analyses done as part of this study add to the understanding of the effects human activities have on the quantity and quality of water to support local ecosystem needs.

\section{Purpose and Scope}

The two main objectives for this study were (1) to assess the degree and extent of changes in physical characteristicschannel geometry, suspended sediment concentrations, and turbidity - and in the benthic macroinvertebrate populations from data collected over 10 years, and (2) to identify any discernible and statistically significant relations among the observed changes. The before-construction phase measurements and samples established the baselines used to calculate deviations in the physical characteristics and benthic macroinvertebrate populations for the during- and after-culvert construction phases.

\section{General Study Site Description}

Six sites located in the northern East Gulf Coastal Plain Physiographic Section (hereinafter referred to as the Coastal Plain) of Alabama were selected for use in this study. The six sites are all within 50 miles of the Fall Line, which defines the northern boundary of the Coastal Plain, and these sites are spread across the State from Russell County, bordering Georgia, to Lamar County, bordering Mississippi (fig. 1; table 1). The current conditions of streams and their watersheds reflect the interactions among the local geology, soils, topography, hydrology, climate, and land cover over human and geological time scales.

Twelve USGS streamgage stations were established for this study (table 1). Two stations at each study site, one at the upstream end of the culvert construction reach and the second at the downstream end of the culvert construction reach. The streamflow and sediment information collected for this study is associated with the respective streamgage and is available through the USGS National Water Information System database (U.S. Geological Survey, 2020).

Alternative culvert designs developed to reduce the impact of stream roadway crossings on fish, sediment, and debris include buried or embedded inverts (inside bottom of the culvert) (National Academies of Sciences, Engineering, and Medicine, 2012). Constructing the culvert inverts below the adjacent upstream and downstream channel reaches allows the streambed through the culvert to aggregate and erode at natural rates, greatly reducing the potential for perched inlets or outlets which often occur with culverts using traditional designs (National Academies of Sciences, Engineering, and Medicine, 2012). Buried culvert invert designs were used at the Tributary to Cahaba River (site 2) and the Tributary to Sandy Creek sites (table 2).

\section{Geology and Soils}

The geology underlying the six study sites consists of relatively young sedimentary rocks and unconsolidated sediments. During the Late Cretaceous period (approximately 70-65 mega-annum [MA] before present), the area was repeatedly inundated by shallow seas, resulting in an alternating sequence of marine and continental sediments. Subsequently, fluvial drainage networks were established and distributed continental sediments across the Coastal Plain. Most recently, during the Quaternary period (approximately 2.6 MA before present through the present), this drainage network continues to distribute sediments from the areas north of the Fall Line, and has redistributed existing sediments forming the hills, valleys, and terraces that exist today (fig. 2; table 3). The geologic units underlying the study sites slope southward at about 40 feet per mile and consist predominantly of chalk, sandstone, limestone, and claystone; the unconsolidated sediments are predominantly sands, silts, and clays (Hosman, 1991; Neilson, 2016).

The soils within the study basins have formed over time by the physical, chemical, and biological weathering of sedimentary rocks of Cretaceous age and the unconsolidated sediments of Cretaceous and Quaternary ages. The major soil series at the study sites include Smithdale, Luverne, and Savannah (table 4). These soils have either a loamy or clayey subsoil and a sandy loam or loam surface layer. Savannah soils have a fragipan (Mitchell and Loerch, 2008).

\section{Topography}

The subtle topography of the northern Coastal Plain consists of level to gently rolling hills, terraces, and prairies. The topography is governed by the rocks that underlie the surface and the erosional forces that have acted upon them. Because most of the sediments of Tertiary and Quaternary ages in the Coastal Plain fall into two major rock types, sandstone and shale, erosional processes have had similar effects throughout the area. The more resistant sand layers underlie ridges or cuestas, and the less resistant shale layers underlie the topographic lows or valleys (Hosman, 1991). In the Coastal Plain of Alabama, cuestas (hills or ridges where layered, harder sedimentary rock overlie softer sedimentary rock) trend eastwest, with the gentle backslopes facing south and the steeper frontslopes facing north (Cotton, 1952). 
Table 1. Site numbers and names with associated USGS streamgage stations, drainage area, locations, and stream order information.

[USGS, U.S. Geological Survey; mi² $^{2}$ square mile; latitudes and longitudes are in degrees, minutes, seconds, referenced to the North American Datum of 1927; Trib, tributary; Ala., Alabama; Stream order less than $(<) 1$, Stream is not mapped in the National Hydrography Dataset and therefore is smaller than a first-order stream]

\begin{tabular}{|c|c|c|c|c|c|c|c|c|c|}
\hline $\begin{array}{c}\text { Site } \\
\text { number } \\
\text { (fig. 1) }\end{array}$ & $\begin{array}{l}\text { Abbreviated } \\
\text { site name }\end{array}$ & $\begin{array}{c}\text { USGS } \\
\text { station } \\
\text { number } 1\end{array}$ & USGS station name ${ }^{1}$ & $\begin{array}{c}\text { Drainage } \\
\text { area } \\
\left(\mathrm{mi}^{2}\right)\end{array}$ & Latitude & Longitude & County & $\begin{array}{l}\text { Highway or road } \\
\text { near streamgage }\end{array}$ & $\begin{array}{c}\text { Stream } \\
\text { order }\end{array}$ \\
\hline \multirow[t]{2}{*}{1} & \multirow[t]{2}{*}{ High Log Creek } & 02342870 & High Log Creek (Site A) near Hatchechubbee, Ala. & \multirow[t]{2}{*}{13.7} & $32^{\circ} 16^{\prime} 21^{\prime \prime}$ & $85^{\circ} 17^{\prime} 58^{\prime \prime}$ & \multirow[t]{2}{*}{ Russell } & \multirow[t]{2}{*}{ State Highway 26} & \multirow[t]{2}{*}{1} \\
\hline & & 02342871 & High Log Creek (Site B) near Hatchechubbee, Ala. & & $32^{\circ} 16^{\prime} 20^{\prime \prime}$ & $85^{\circ} 17^{\prime} 58^{\prime \prime}$ & & & \\
\hline \multirow[t]{2}{*}{2} & \multirow{2}{*}{$\begin{array}{l}\text { Tributary to } \\
\text { Cahaba River }\end{array}$} & 02423990 & Tributary to Cahaba River (Site A) near Centreville, Ala. & \multirow[t]{2}{*}{0.39} & $32^{\circ} 57^{\prime} 23^{\prime \prime}$ & $87^{\circ} 07^{\prime} 33^{\prime \prime}$ & \multirow[t]{2}{*}{ Bibb } & \multirow{2}{*}{$\begin{array}{l}\text { U.S. Highway } 82- \\
\text { State Route } 6\end{array}$} & \multirow[t]{2}{*}{$<1$} \\
\hline & & 02423991 & Tributary to Cahaba River (Site B) near Centreville, Ala. & & $32^{\circ} 57^{\prime} 24^{\prime \prime}$ & $87^{\circ} 07^{\prime} 33^{\prime \prime}$ & & & \\
\hline \multirow[t]{2}{*}{3} & \multirow{2}{*}{$\begin{array}{l}\text { Tributary to } \\
\text { Sandy Creek }\end{array}$} & 02424013 & Tributary to Sandy Creek (Site A) near Vick, Ala. & \multirow[t]{2}{*}{1.34} & $32^{\circ} 56^{\prime} 23^{\prime \prime}$ & $87^{\circ} 04^{\prime} 27^{\prime \prime}$ & \multirow[t]{2}{*}{ Bibb } & \multirow{2}{*}{$\begin{array}{l}\text { U.S. Highway } 82- \\
\text { State Route } 6\end{array}$} & \multirow[t]{2}{*}{$<1$} \\
\hline & & 02424014 & Tributary to Sandy Creek (Site B) near Vick, Ala. & & $32^{\circ} 56^{\prime} 22^{\prime \prime}$ & $87^{\circ} 04^{\prime} 27^{\prime \prime}$ & & & \\
\hline \multirow[t]{2}{*}{4} & \multirow{2}{*}{$\begin{array}{l}\text { Oakmulgee } \\
\text { Creek }\end{array}$} & 02424750 & Oakmulgee Creek (Site A) near Lawley, Ala. & \multirow[t]{2}{*}{12.5} & $32^{\circ} 50^{\prime} 34^{\prime \prime}$ & $86^{\circ} 57^{\prime} 30^{\prime \prime}$ & \multirow[t]{2}{*}{ Bibb } & \multirow{2}{*}{$\begin{array}{l}\text { U.S. Highway } 82- \\
\text { State Route } 6\end{array}$} & \multirow[t]{2}{*}{2} \\
\hline & & 02424751 & Oakmulgee Creek (Site B) near Lawley, Ala. & & $32^{\circ} 50^{\prime} 34^{\prime \prime}$ & $86^{\circ} 57^{\prime} 31^{\prime \prime}$ & & & \\
\hline \multirow[t]{2}{*}{5} & \multirow{2}{*}{$\begin{array}{l}\text { Northington } \\
\text { Branch }\end{array}$} & 02439159 & Northington Branch near Detroit, Ala., Site A & \multirow[t]{2}{*}{6.22} & $34^{\circ} 00^{\prime} 58^{\prime \prime}$ & $88^{\circ} 11^{\prime} 50^{\prime \prime}$ & \multirow[t]{2}{*}{ Lamar } & \multirow{2}{*}{$\begin{array}{l}\text { County Road } 5 \text { - } \\
\text { Sipsey Fork Road }\end{array}$} & \multirow[t]{2}{*}{1} \\
\hline & & 02439160 & Northington Branch near Detroit, Ala., Site B & & $34^{\circ} 00^{\prime} 58^{\prime \prime}$ & $88^{\circ} 11^{\prime} 51^{\prime \prime}$ & & & \\
\hline \multirow[t]{2}{*}{6} & \multirow[t]{2}{*}{ Lye Branch } & 02465390 & Lye Branch (Site A) near Duncanville, Ala. & \multirow[t]{2}{*}{16.4} & $33^{\circ} 05^{\prime} 07^{\prime \prime}$ & $87^{\circ} 23^{\prime} 35^{\prime \prime}$ & \multirow[t]{2}{*}{ Tuscaloosa } & \multirow[t]{2}{*}{ Hargrove Road } & \multirow[t]{2}{*}{3} \\
\hline & & 02465391 & Lye Branch (Site B) near Duncanville, Ala. & & $33^{\circ} 05^{\prime} 06^{\prime \prime}$ & $87^{\circ} 23^{\prime} 35^{\prime \prime}$ & & & \\
\hline
\end{tabular}

'USGS National Water Information System database (U.S. Geological Survey, 2020. 


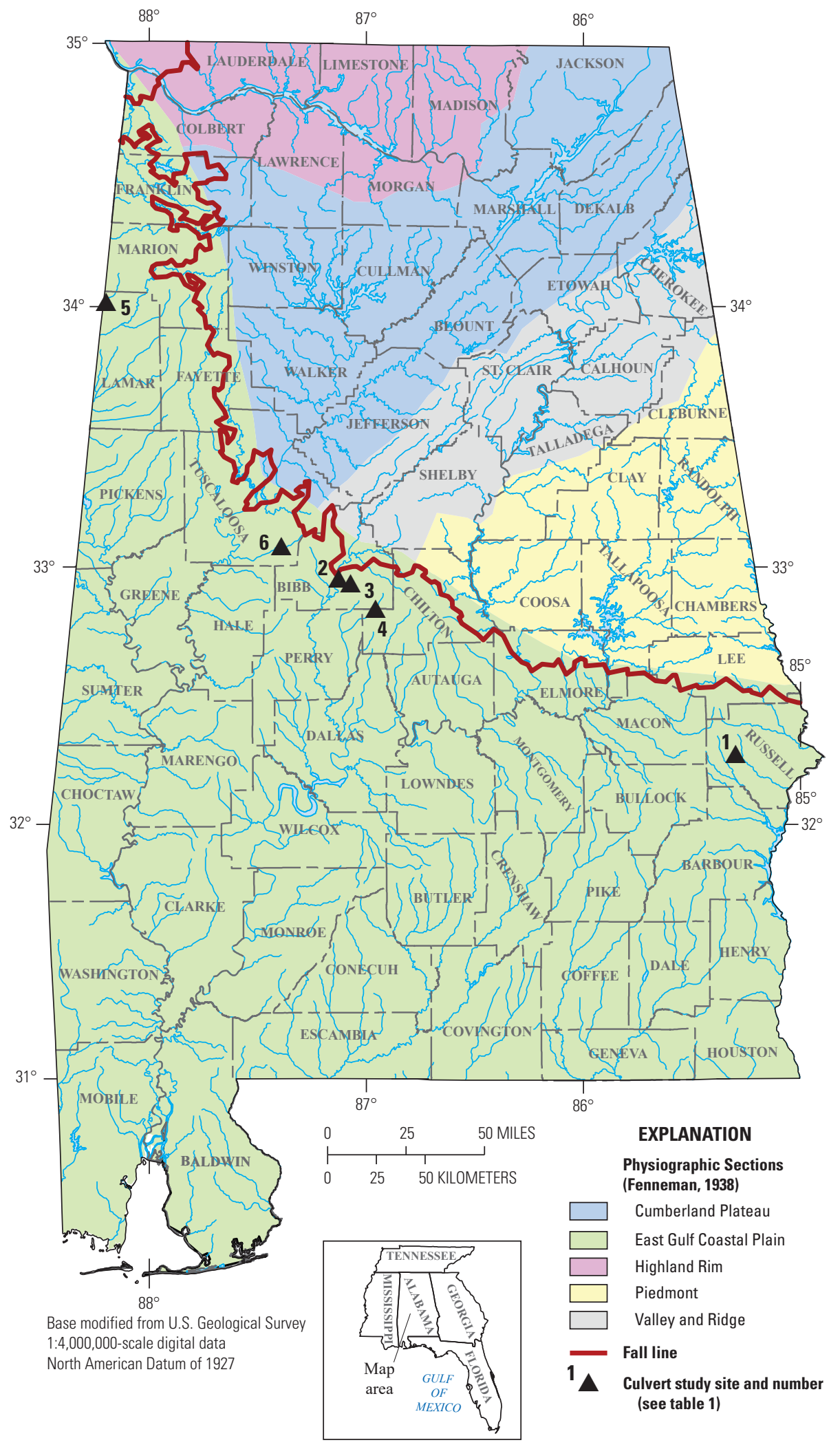

Figure 1. Locations of sites used in the culvert study and Physiographic Sections of Alabama. The culvert site number in the figure references table 1 where site 1 is High Log Creek, site 2 is Tributary to Cahaba River, site 3 is Tributary to Sandy Creek, site 4 is Oakmulgee Creek, site 5 is Northington Branch, and site 6 is Lye Branch. 
Table 2. Alabama Department of Transportation construction information for culverts at six sites in Alabama.

[Construction dates shown in month/day/year format; $\mathrm{BW} \times \mathrm{BH} \times \mathrm{BL}$, barrel width $\times$ barrel height $\times$ barrel length; ft, foot; BIN, Bridge Identification Number; CIP, cast in place; $\mathrm{CT}$, triple barrel culvert; $\mathrm{CS}$, single barrel culvert; CQ, quadruple barrel culvert; NA, not applicable; Note: construction information provided by the Alabama Department of Transportation]

\begin{tabular}{|c|c|c|c|c|c|c|c|c|}
\hline $\begin{array}{l}\text { Site number } \\
\text { (fig. 1; } \\
\text { table 1) }\end{array}$ & Abbreviated site name & $\begin{array}{l}\text { Construction } \\
\text { start date }\end{array}$ & $\begin{array}{l}\text { Construction } \\
\text { end date }\end{array}$ & Type of culvert & $\begin{array}{c}\text { Culvert } \\
\text { dimensions, } \\
B W \times B H \times B L \\
(f t)\end{array}$ & $\begin{array}{l}\text { Buried } \\
\text { invert } \\
\text { culvert } \\
\text { design }\end{array}$ & BIN & Project number \\
\hline 1 & High Log Creek & $8 / 28 / 2013$ & $9 / 28 / 2016$ & CIP concrete & CT16×14×78 & No & 20483 & BR-0026(502) \\
\hline 2 & Tributary to Cahaba River & $11 / 2 / 2010$ & $8 / 16 / 2013$ & Precast box culvert & $\mathrm{CS} 10 \times 6 \times 229$ & Yes & NA & NHF-0006(530) \\
\hline 3 & Tributary to Sandy Creek & $11 / 2 / 2010$ & $8 / 16 / 2013$ & CIP concrete & $\mathrm{CT} 12 \times 7 \times 286$ & Yes & 20354 & NHF-0006(530) \\
\hline 4 & Oakmulgee Creek & $10 / 29 / 2013$ & $3 / 26 / 2015$ & CIP concrete & CT16×14×44 & No & 20562 & BRF-0006(541) \\
\hline 5 & Northington Branch & $10 / 5 / 2011$ & $4 / 1 / 2013$ & CIP concrete & CT $12 \times 8 \times 42$ & No & 20506 & BRZ-3800(209) \\
\hline 6 & Lye Branch & $11 / 6 / 2013$ & $12 / 13 / 2018$ & CIP concrete & CQ14×8×60 & No & 20673 & BRZ-6300(220) \\
\hline
\end{tabular}


Table 3. Surficial geology mapped within selected stream reach drainage basins in Alabama.

[Fm, Formation; From Szabo and others, 1988]

\begin{tabular}{|c|c|c|c|c|c|c|c|}
\hline & & \multicolumn{6}{|c|}{ Site number and abbreviated name (fig. 2; table 1) } \\
\hline & & 1 & 2 & 3 & 4 & 5 & 6 \\
\hline & & $\begin{array}{l}\text { High Log } \\
\text { Creek }\end{array}$ & $\begin{array}{l}\text { Tributary to } \\
\text { Cahaba River }\end{array}$ & $\begin{array}{l}\text { Tributary to } \\
\text { Sandy Creek }\end{array}$ & $\begin{array}{c}\text { Oakmulgee } \\
\text { Creek }\end{array}$ & $\begin{array}{c}\text { Northington } \\
\text { Branch }\end{array}$ & $\begin{array}{c}\text { Lye } \\
\text { Branch }\end{array}$ \\
\hline System & Series & \multicolumn{6}{|c|}{ Unit name } \\
\hline Quaternary & Holocene & & & Alluvium & Alluvium & Alluvium & Alluvium \\
\hline Cretaceous & & $\begin{array}{l}\text { Mooreville } \\
\text { Chalk, } \\
\text { Blufftown } \\
\text { Fm }\end{array}$ & Coker Fm & Coker Fm & $\begin{array}{l}\text { Gordo Fm, } \\
\text { Coker Fm }\end{array}$ & $\begin{array}{l}\text { Eutaw Fm, } \\
\text { Gordo Fm }\end{array}$ & Coker Fm \\
\hline
\end{tabular}

\section{Hydrology}

Stream order is a positive number indicating the position of a stream in the hierarchy of tributaries (Leopold, 1994). Stream order is an effective way to classify streams and assist in understanding and managing the many differences between streams of different sizes. The Horton-Strahler stream order system is a "top down" system (Horton, 1945; Strahler, 1957). First- through third-order streams are headwater streams that have formed on steeper slopes and have faster flows and smaller volumes. Fourth- through sixth-order streams are medium streams with less slope, slower flows, and larger volumes. Stream orders greater than sixth are large rivers; for example, the Ohio River is an 8th-order stream, and the Mississippi River is a10th-order stream. The stream orders for the streams at the selected study sites were determined by using the Horton-Strahler method and the National Hydrography Dataset (1:24,000 scale) (U.S. Geological Survey, 2017). All the streams at the selected study sites are headwater streams of third-order or less with drainage areas from 0.39 to 16.4 square miles $\left(\mathrm{mi}^{2}\right)$ (table 1$)$.

Hydrologic units and the associated watershed boundary datasets are used to delineate the areal extent of surface-water drainage in the United States. A hierarchical classification system is used to subdivide river basins into successively smaller basins (Seaber and others, 1987). At least one study reach is within each of the three subregional hydrologic units that drain the northern part of the Coastal Plain in Alabama (fig. 3; table 5). High Log Creek (site 1) is within the Apalachicola subregion. Cahaba River (site 2), Sandy Creek (site 3), and Oakmulgee Creek (site 4) are within the Alabama subregion, and Northington Branch (site 5) and Lye Branch (site 6) are within the Mobile-Tombigbee subregion.
Culvert design is predominantly based on the estimated peak streamflow that the structure is designed to convey (Norman and others, 2005). Streamflow estimates for floods having recurrence intervals of $1.5,2,5,10,25,50,100$, 200 , and 500 years were made by using USGS regional flood-frequency relations for Alabama (Hedgecock, 2004; Hedgecock and Feaster, 2007).

To facilitate comparisons among the different sites, only the 2-year peak streamflow estimates were used. The 2-year peak streamflow estimates for the six study reaches range from 94.0 cubic feet per second $\left(\mathrm{ft}^{3} / \mathrm{s}\right)$ for the Tributary to Cahaba River (site 2) to $1,060 \mathrm{ft}^{3} / \mathrm{s}$ at the Lye Branch site (table 6).

\section{Climate}

The Coastal Plain has a generally warm, humid climate resulting from its mid-latitude location and proximity to the Gulf of Mexico. This location produces turbulent weather patterns that regularly bring tornadoes and hurricanes. Alabama is classified as being in the Humid Subtropical region according to the Koppen classification system, where the climate is characterized by relatively mild winters, hot summers, and year-round precipitation (Chaney, 2013). The average annual precipitation in the Coastal Plain is between 52 and 56 inches with an average annual temperature between 60 and 64 degrees Fahrenheit. The length of the growing season for agricultural production varies from approximately 200 to 220 days per year (University of Alabama, 2017). 


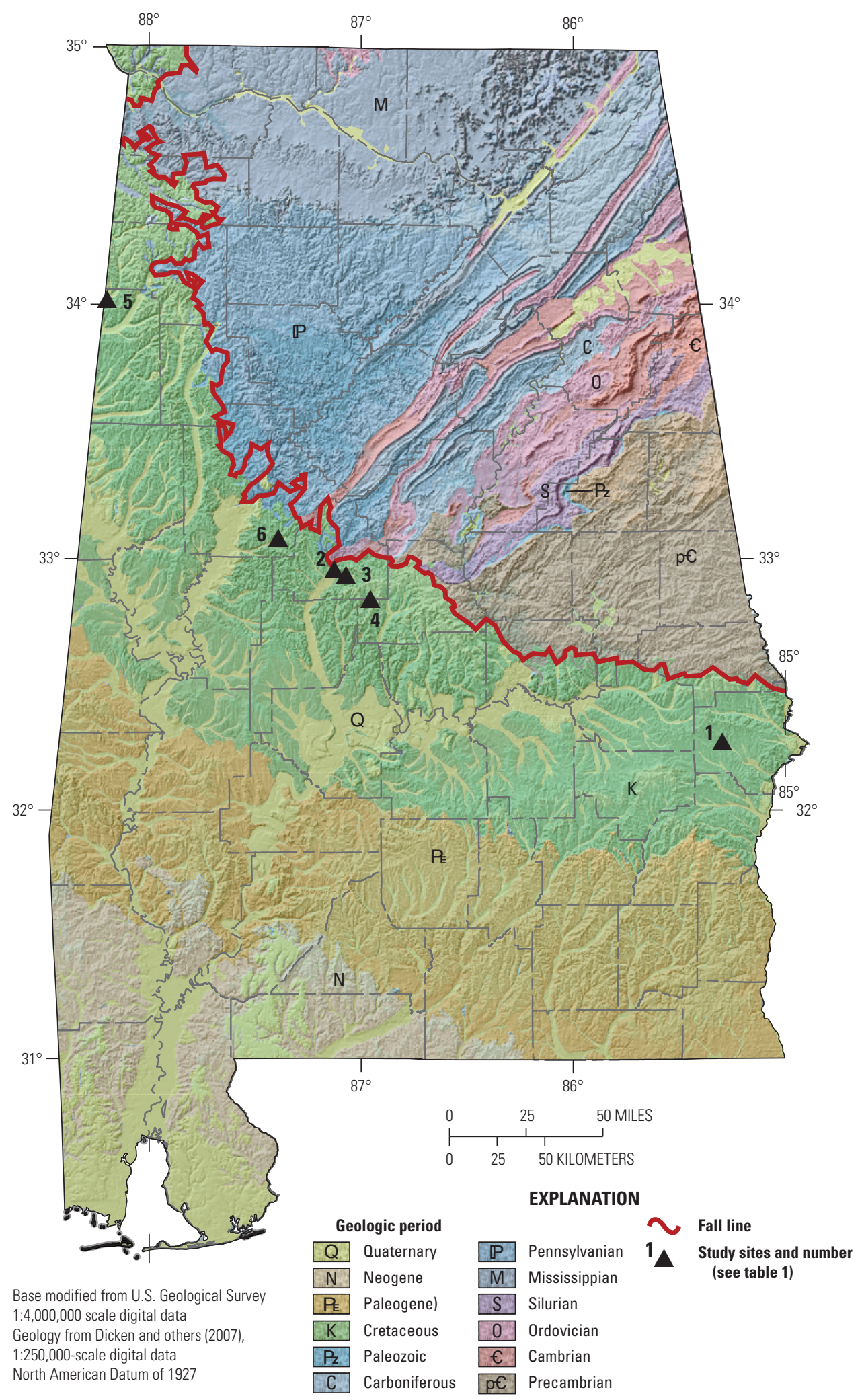

Figure 2. Locations of sites used in the culvert study and generalized surficial geology of Alabama. The culvert site number in the figure references table 1 where site 1 is High Log Creek, site 2 is Tributary to Cahaba River, site 3 is Tributary to Sandy Creek, site 4 is Oakmulgee Creek, site 5 is Northington Branch, and site 6 is Lye Branch. 
Table 4. Soil series mapped within selected stream reach drainage basins in Alabama.

[From Soil Survey Staff, Natural Resources, United States Department of Agriculture]

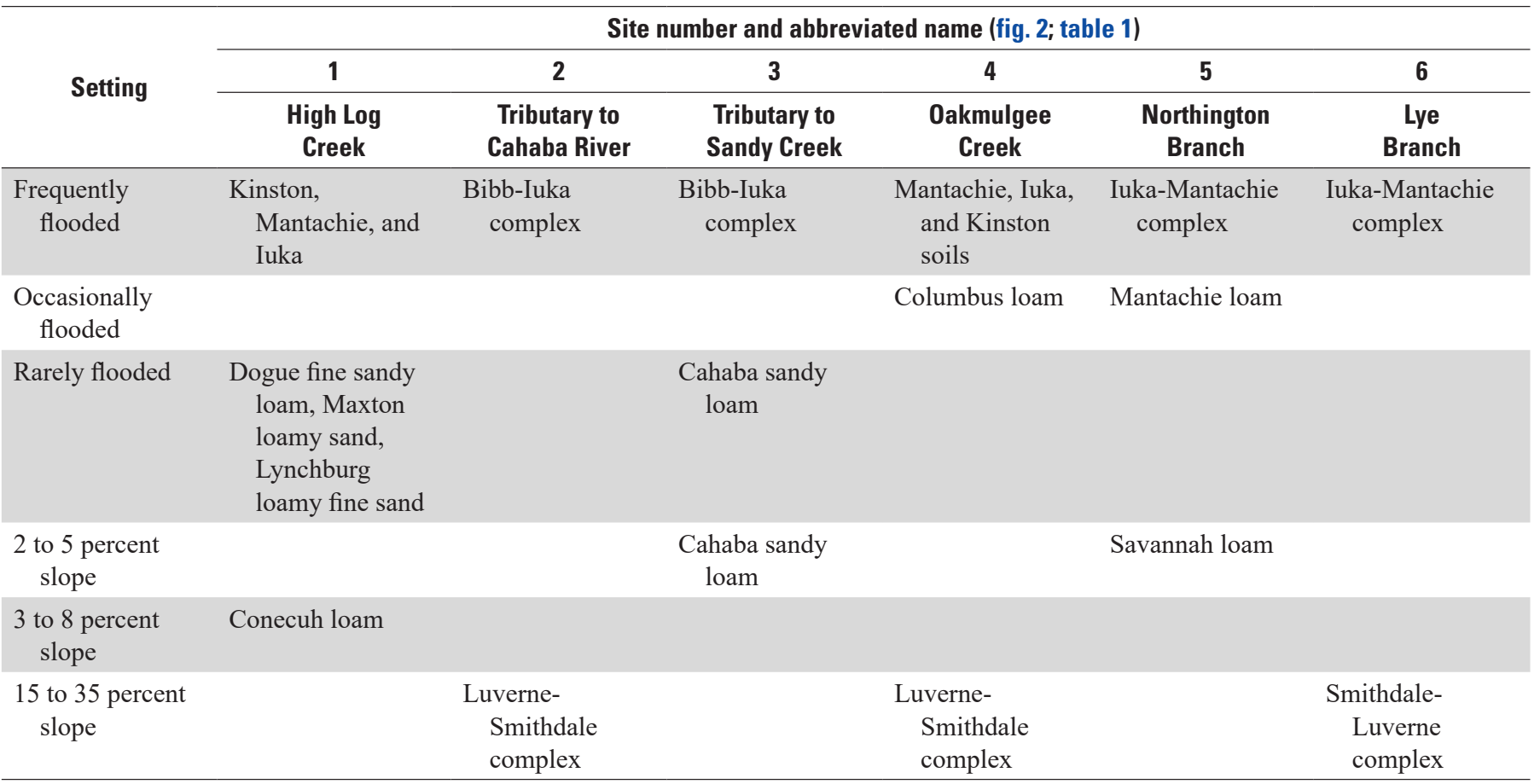

Table 5. Hydrologic units in which selected study sites are located in Alabama.

[Hydrologic units are from Seaber and others (1987)]

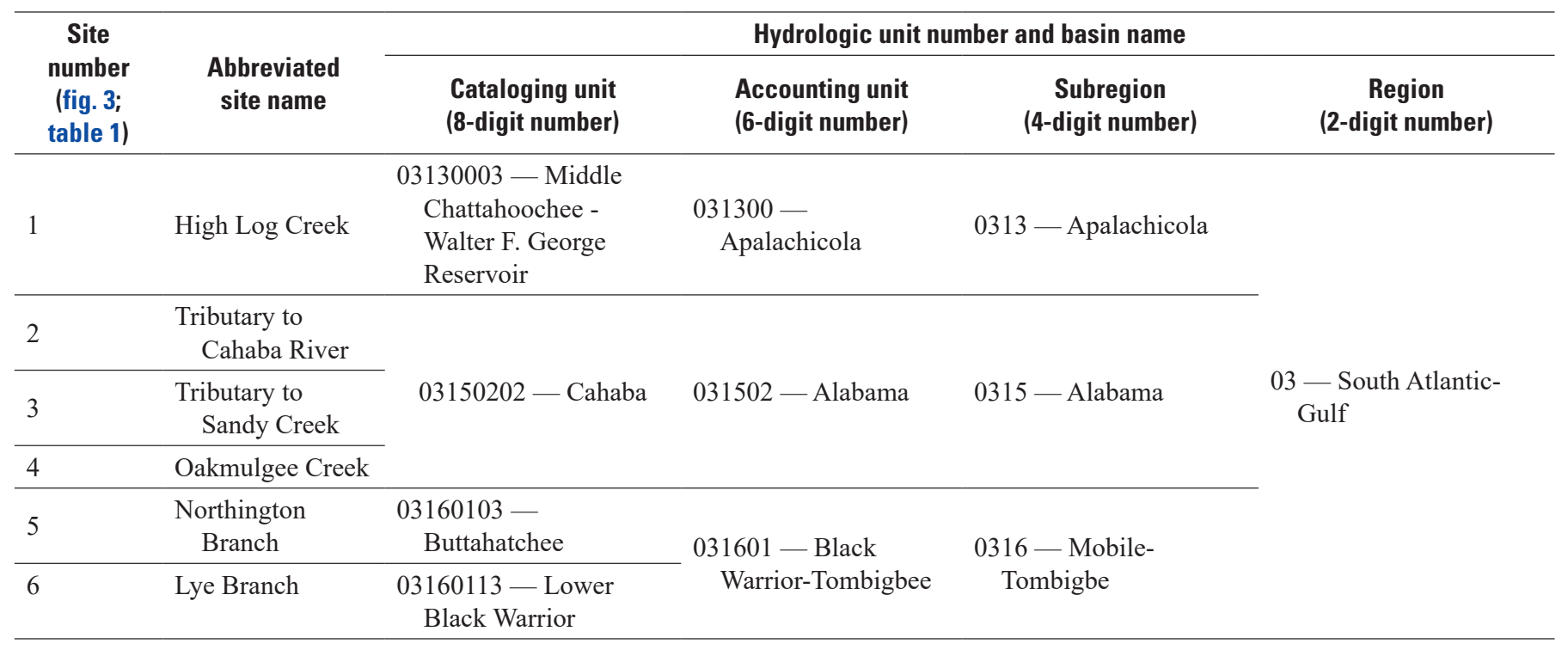




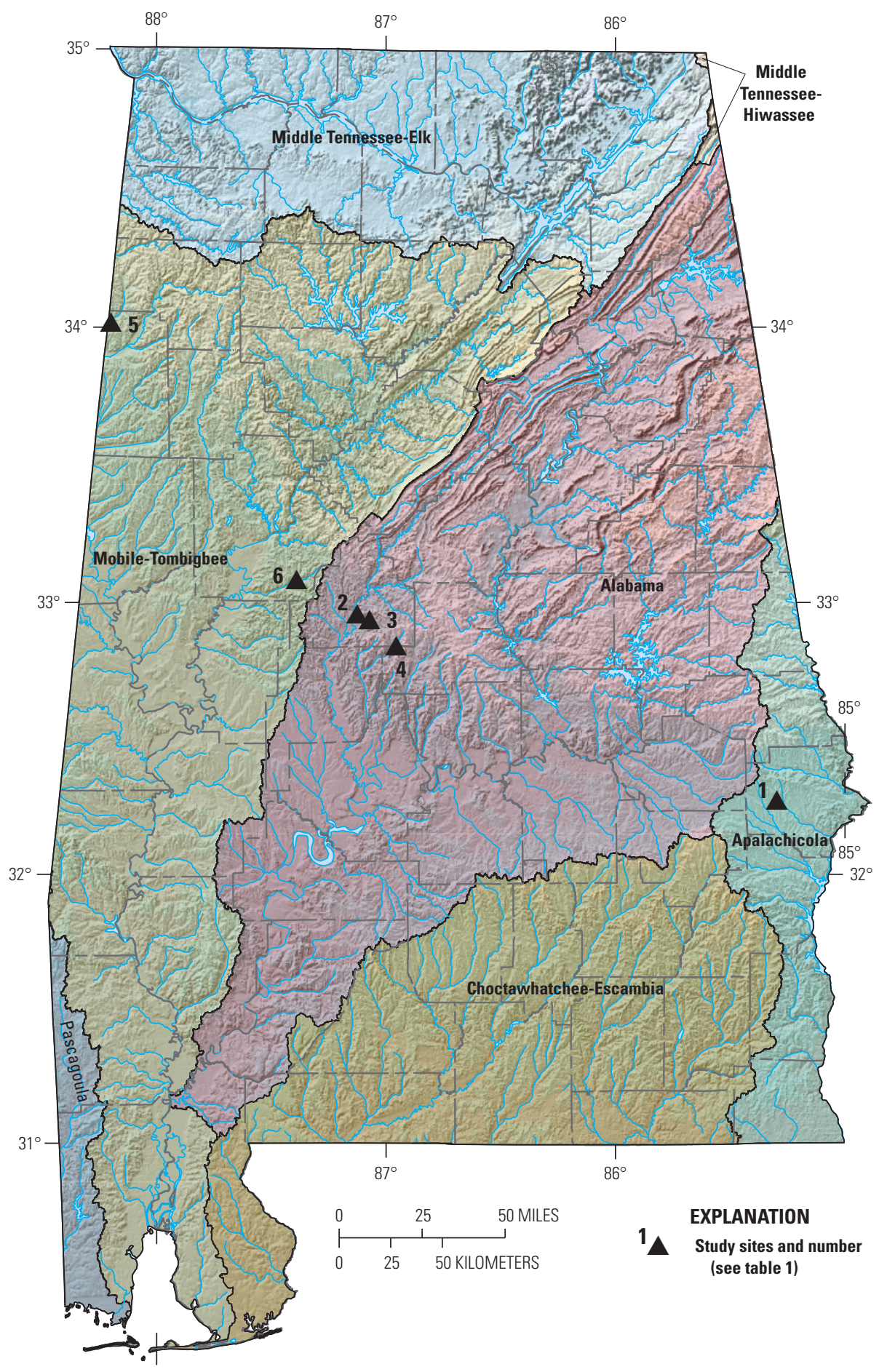

Base modified from U.S. Geological Survey

1:4,000,000-scale digital data

North American Datum of 1927

Figure 3. Locations of sites used in the culvert study and hydrologic subregions of Alabama. The culvert site number in the figure references table 1 where site 1 is High Log Creek, site 2 is Tributary to Cahaba River, site 3 is Tributary to Sandy Creek, site 4 is Oakmulgee Creek, site 5 is Northington Branch, and site 6 is Lye Branch. 
Table 6. Estimates of peak streamflow from regional regression relations at six study sites in Alabama.

[Ala., Alabama; $\mathrm{mi}^{2}$, square mile; $\mathrm{ft}^{3} / \mathrm{s}$, cubic foot per second; \%, percent; N/A, not applicable]

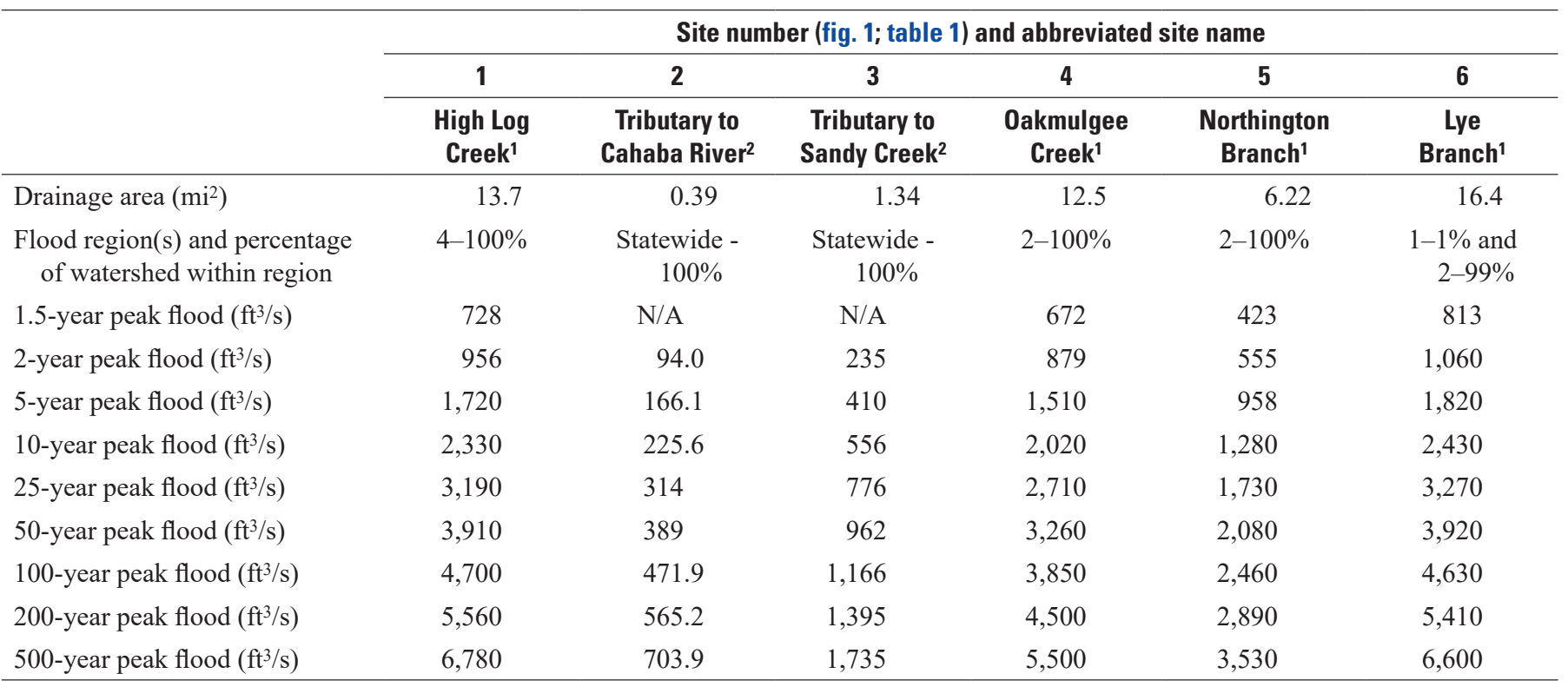

${ }^{1}$ Peak streamflow estimated by using Hedgecock and Feaster (2007).

${ }^{2}$ Peak streamflow estimated by using Hedgecock (2004).

\section{Land Cover}

Land cover is the physical material covering the earth's surface. The land cover of the Coastal Plain is predominantly a mosaic of cropland, pasture, woodland, and forest. The woodlands and forest are mostly oak-hickory-pine and Southern mixed forest (Griffith and others, 2001). The drainage basins above sites 2-6 are within the Fall Line Hills Ecoregion and are mostly forests of mixed oak-hickory-pine and pine plantations with areas of pasture and hay and minor areas of cultivated cropland of corn, soybeans, and cotton (Griffith and others, 2001). The drainage basin above High Log Creek (site 1; fig. 1) is within the Flatwoods Ecoregion, which is a lowland area of little relief, deep soils, and dry woodlands of post oak (Quercus stellata Wangenh.), shortleaf pine (Pinus echinata Mill.), and loblolly pine (Pinus taeda L.) (Griffith and others, 2001).
Data from the National Land Cover Database (U.S. Geological Survey, 2011) was used to determine the land cover on each of the drainage basins above the selected study reaches and used to help evaluate the potential for anthropogenic activities affecting the stream channel (tables 7 and 8). Forest and grassland/shrub are the dominant land cover classes, on average covering 69.5 and 20.3 percent, respectively, of the drainage basins above the study reaches. The five remaining land cover classes - open water, urban, barren, agriculture, and wetlands - each on average covered less than 5 percent of the study reaches' drainage basins. The large percentages of forest and grassland/shrub land cover and the small percentages of urban and agriculture land cover suggest that the watersheds are minimally affected by anthropogenic activities above the selected study reaches. 
Table 7. Land cover within the drainage basins above the selected study sites in Alabama.

$\left[\mathrm{mi}^{2}\right.$, square mile; Land cover from National Land Cover Database (U.S. Geological Survey, 2011). The classification system used by the National Land Cover Database (U.S. Geological Survey, 2011) is modified from the Anderson Land Classification System (Anderson and others, 1976)]

\begin{tabular}{|c|c|c|c|c|c|c|c|c|c|}
\hline \multirow{2}{*}{$\begin{array}{c}\text { Site } \\
\text { number } \\
\text { (fig. 1) }\end{array}$} & \multirow{2}{*}{$\begin{array}{l}\text { Abbreviated } \\
\text { site name }\end{array}$} & \multirow{2}{*}{$\begin{array}{c}\text { Drainage } \\
\text { area } \\
\left(\mathrm{mi}^{2}\right)\end{array}$} & \multicolumn{7}{|c|}{ Level I land cover class within watershed (percent) (see table 8) } \\
\hline & & & $\begin{array}{l}\text { Open } \\
\text { water }\end{array}$ & Urban & Barren & Forest & $\begin{array}{l}\text { Grassland/ } \\
\text { Shrub }\end{array}$ & Agriculture & Wetlands \\
\hline 2 & $\begin{array}{l}\text { Tributary to } \\
\text { Cahaba River }\end{array}$ & 0.39 & 2.5 & 6.2 & 0.0 & 79.7 & 10.9 & 0.2 & 0.5 \\
\hline 3 & $\begin{array}{l}\text { Tributary to } \\
\text { Sandy Creek }\end{array}$ & 1.34 & 0.6 & 1.7 & 0.0 & 83.8 & 10.5 & 3.5 & 0.0 \\
\hline 4 & $\begin{array}{l}\text { Oakmulgee } \\
\text { Creek }\end{array}$ & 12.50 & 0.3 & 3.5 & 0.0 & 54.3 & 30.1 & 8.8 & 3.1 \\
\hline 5 & $\begin{array}{c}\text { Northington } \\
\text { Branch }\end{array}$ & 6.22 & 0.0 & 3.1 & 0.1 & 66.9 & 21.2 & 7.7 & 0.9 \\
\hline 6 & Lye Branch & 16.40 & 0.7 & 3.4 & 0.1 & 66.2 & 24.6 & 2.6 & 2.4 \\
\hline
\end{tabular}

Table 8. Land cover class descriptions associated within the drainage basins above the selected study sites in Alabama.

[Land cover from National Land Cover Database (U.S. Geological Survey, 2011). The classification system used by National Land Cover Database (U.S. Geological Survey, 2011) is modified from the Anderson Land Classification System (Anderson and others, 1976)]

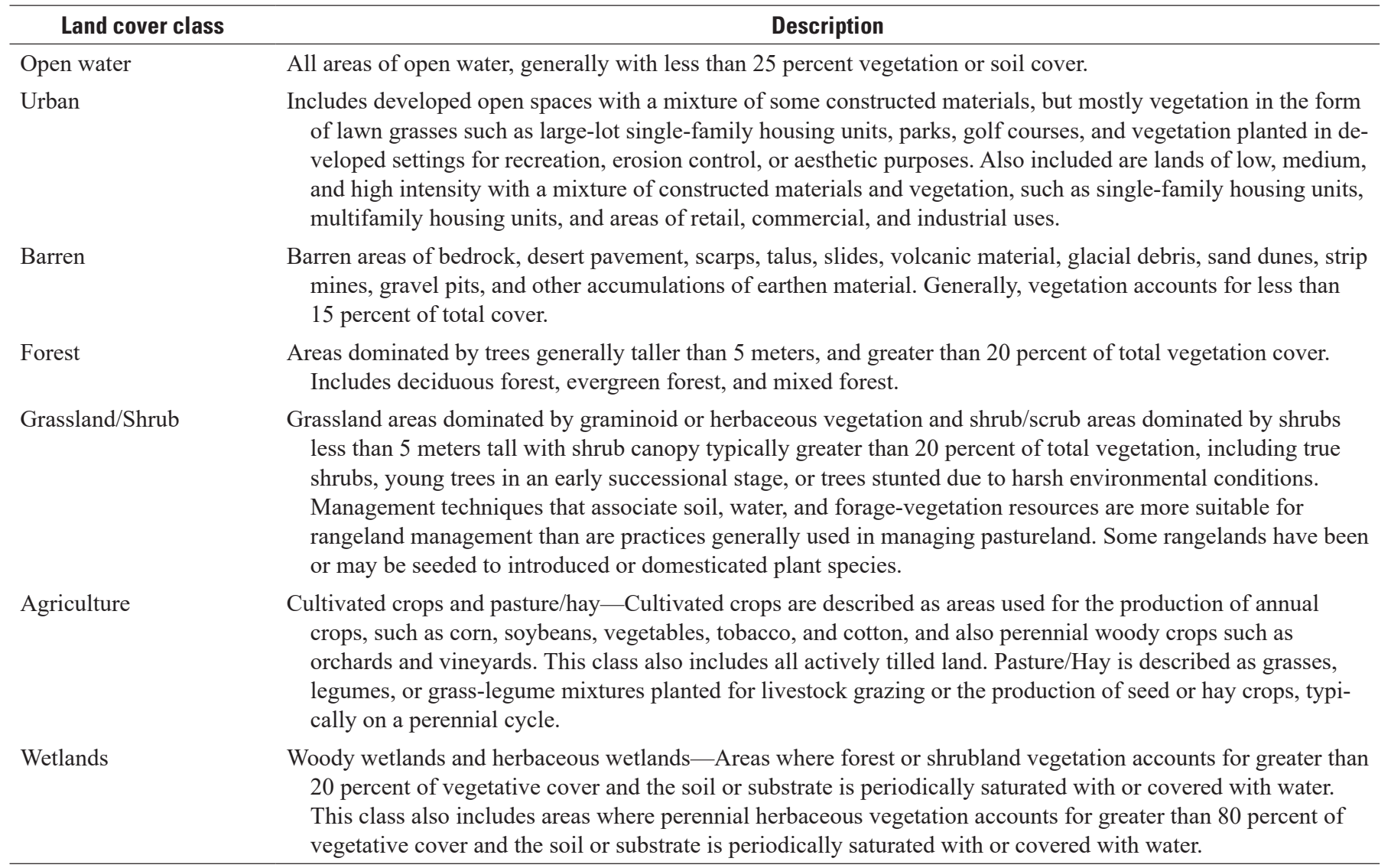




\section{Methods}

The following discussions describe the site selection process and sampling methods used at each study site. Types of samples and data collected included stream geometry surveys, suspended sediment and turbidity sampling, streamflow measurements, and benthic macroinvertebrate community sampling.

\section{Site Selection}

To maximize the homogeneity of stream features, all sites were located within the northern East Gulf Coastal Plain Physiographic Section in Alabama (Fenneman, 1938) (fig. 1). The streams of the Coastal Plain were considered the most likely to be affected by culvert construction because of the loose, shifting sand composing the streambed and banks.

The initial list of candidate sites was developed in consultation with ALDOT personnel. Selection criteria included candidate sites that had proposed box culverts, with no internal drop structures, relatively small drainage areas, and minimal human development (tables 1, 2, 7, and 8). Choosing sites with minimal anthropogenic influences maximizes the potential that observed changes are the result of culvert construction and not from other human activities.

During the fall of 2009, thorough field assessments were conducted at each candidate site to assess in-stream habitat and stream channel and riparian stability and to determine if site-specific modifications to data collection methods would be required. Choosing stable streams maximizes the potential that observed changes are the result of culvert construction and not a pre-existing instability. The final site selection was based on the site selection criteria and the observations made during site visits.

\section{Stream Channel Geometry Surveys}

Topographic surveys of 22 stream channel cross sections, 11 upstream and 11 downstream of the culvert construction, were conducted prior to culvert construction to provide a baseline to compare to the effects culvert construction may have on the stream channel beds, banks, and slopes. These topographic surveys were conducted outside of the right-of-way boundaries to avoid possible effects of construction. The cross sections were evenly distributed along a stream reach length of approximately 20 times the channel width. These same cross sections were resurveyed approximately 2 years after culvert construction was completed. Topographic survey data and map view plots of the survey data for each study site are available from Gill and Pugh (2021).

Analysis of data in this report includes comparisons of data from the upstream and the downstream reaches to evaluate the construction reach. The upstream reach is defined as the stream reach containing the 11 cross sections upstream of the culvert construction. The construction reach is defined as the stream reach between the right-of-way boundaries where culvert construction occurred. The downstream reach is defined as the stream reach containing the 11 cross sections downstream of the culvert construction.

A paired sample t-test of the mean cross-sectional parameters (cross-sectional area, top width, and mean depth) was used to assess before- and after-construction changes (table 9). The means of the before-construction, upstream, cross-sectional parameters were compared to the means of the after-construction, upstream, cross-sectional parameters, where the hypothesized mean difference was 0 and the alpha was 0.05 . This technique was also used to assess the change between the before- and after-construction, downstream crosssectional parameters.

A paired sample t-test for slopes of regression lines was used to assess the change between before- and afterconstruction channel thalweg slopes (table 10). The thalweg is defined as a line connecting the lowest points of successive cross sections along the stream (fig. 4). The slope of the before-construction, upstream thalweg was compared to the slope of the after-construction, upstream thalweg, where the hypothesized mean difference was 0 and the alpha was 0.05 . This technique was also used to assess the change between the before- and after-construction, downstream thalweg slopes.

A statistically significant result for the differences between before- and after-construction observations indicates a high probability that the difference was real and not due to chance. It also means there is a 5-percent $(\alpha=0.05)$ probability that the difference is due to chance. A statistically significant result only indicates that there is a difference, not the magnitude of the difference.

\section{Suspended Sediment and Turbidity Sampling}

Suspended sediment samples were collected at each study site during multiple storm runoff events, both upstream and downstream of the culvert construction reach, at the same time steps throughout each storm event. Discrete samples were collected at various stream stages representing the rising, peaking, and falling stages of the storm hydrograph. Some samples could not be collected because of lack of access to the stream cross sections during high-flow conditions. During flashy storm events with rapidly changing streamflow, sediment analyses did not always include a direct simultaneous measurement of streamflow. Because streamflow could not be accurately determined for each set of samples, data analysis focused on the parity of the upstream and downstream sediment concentrations for each discrete sample collection time. Suspended sediment samples were collected by using equal-width increment methods as described in Techniques of Water-Resources Investigations of the U.S. Geological Survey, book 3, chapter C2 (Edwards and Glysson, 1999). For some events, multiple sample bottles were collected for a discrete time step and composited in a churn splitter. The churn splitter was used to homogenize the composite sample and fill a single 
Table 9. Results of paired sample t-tests of mean area, width, and depth at cross sections to determine significant differences between the before- and after-construction parameters at selected study sites in Alabama.

$[\Delta \mathrm{XS}$ area, difference between before- and after-construction cross-sectional areas; $\Delta$ top width, difference between before- and after-construction top widths; $\Delta$ mean depth, difference between before- and after-construction mean depths; $\mathrm{ft}^{2}$, square foot; $\mathrm{ft}$, foot; $\mathrm{n}$, sample size; Std dev; standard deviation; \%, percent; CI, confidence interval. Null Hypothesis $\left(\mathrm{H}_{0}\right)$ : there is no significant difference between the means of the before- and after-construction cross-section indices. Alternate Hypothesis $\left(\mathrm{H}_{\mathrm{A}}\right)$ : there is a significant difference between the means of the before- and after-construction cross-section indices. $\mathrm{H}_{0}: \mu 0=0, \mathrm{H}_{\mathrm{A}}: \mu \mathrm{A} \neq 0$. Hypothesized mean difference: 0 , Alpha $=0.05]$

\begin{tabular}{|c|c|c|c|c|c|c|}
\hline & \multicolumn{3}{|c|}{ Upstream } & \multicolumn{3}{|c|}{ Downstream } \\
\hline & $\begin{array}{c}\Delta \mathrm{XS} \text { area } \\
\left(\mathrm{ft}^{2}\right)\end{array}$ & $\begin{array}{c}\Delta \text { Top width } \\
\text { (ft) }\end{array}$ & $\begin{array}{c}\Delta \text { Mean depth } \\
(\mathrm{ft})\end{array}$ & $\begin{array}{c}\Delta \mathrm{XS} \text { area } \\
\left(\mathrm{ft}^{2}\right)\end{array}$ & $\begin{array}{c}\Delta \text { Top width } \\
\text { (ft) }\end{array}$ & $\begin{array}{c}\Delta \text { Mean depth } \\
\text { (ft) }\end{array}$ \\
\hline $\mathrm{n}$ & 10 & 10 & 10 & 10 & 10 & 10 \\
\hline Mean & -12.85 & 2.30 & -0.52 & 2.37 & 0.90 & -0.10 \\
\hline Two-tail p & 0.03 & 0.06 & 0.00 & 0.56 & 0.18 & 0.35 \\
\hline $\mathrm{T}$ alpha half $95 \% \mathrm{CI}$ & 2.26 & 2.26 & 2.26 & 2.26 & 2.26 & 2.26 \\
\hline Lower 95\% CI & -23.90 & -0.01 & -0.76 & -6.12 & -0.44 & -0.32 \\
\hline Upper 95\% CI & -1.80 & 4.61 & -0.29 & 10.87 & 2.24 & 0.12 \\
\hline Mean & 3.15 & 0.00 & 0.21 & 1.30 & -0.09 & 0.09 \\
\hline Std Dev & 4.28 & 1.69 & 0.24 & 1.84 & 0.79 & 0.13 \\
\hline t Stat & -2.66 & 0.00 & -3.07 & -2.24 & 0.36 & -2.24 \\
\hline Two-tail p & 0.02 & 1.00 & 0.01 & 0.05 & 0.72 & 0.05 \\
\hline $\mathrm{T}$ alpha half $95 \% \mathrm{CI}$ & 2.16 & 2.16 & 2.16 & 2.23 & 2.23 & 2.23 \\
\hline Lower 95\% CI & 0.68 & -0.98 & 0.07 & 0.06 & -0.62 & 0.00 \\
\hline Upper 95\% CI & 5.62 & 0.98 & 0.35 & 2.54 & 0.44 & 0.18 \\
\hline $\mathrm{H}_{0}$ or $\mathrm{H}_{\mathrm{A}}$ & $\mathrm{H}_{\mathrm{A}}$ & $\mathrm{H}_{0}$ & $\mathrm{H}_{\mathrm{A}}$ & $\mathrm{H}_{\mathrm{A}}$ & $\mathrm{H}_{0}$ & $\mathrm{H}_{\mathrm{A}}$ \\
\hline \multicolumn{7}{|c|}{ Tributary to Sandy Creek, site 3} \\
\hline $\mathrm{T}$ alpha half $95 \% \mathrm{CI}$ & 2.26 & 2.26 & 2.26 & 2.26 & 2.26 & 2.26 \\
\hline Lower 95\% CI & -7.89 & -3.32 & -0.16 & -8.68 & -2.08 & -0.25 \\
\hline Upper 95\% CI & 3.76 & 1.52 & 0.10 & 8.49 & 5.08 & 0.01 \\
\hline $\mathrm{H}_{\mathrm{O}}$ or $\mathrm{H}_{\mathrm{A}}$ & $\mathrm{H}_{0}$ & $\mathrm{H}_{0}$ & $\mathrm{H}_{0}$ & $\mathrm{H}_{0}$ & $\mathrm{H}_{0}$ & $\mathrm{H}_{0}$ \\
\hline \multicolumn{7}{|c|}{ Oakmulgee Creek, site 4} \\
\hline $\mathrm{n}$ & 11 & 11 & 11 & 11 & 11 & 11 \\
\hline Mean & -1.77 & 0.36 & -0.06 & 9.31 & -2.82 & 0.56 \\
\hline Std Dev & 20.35 & 4.21 & 0.43 & 44.67 & 4.20 & 0.90 \\
\hline t Stat & 0.28 & -0.27 & 0.41 & -0.66 & 2.12 & -1.95 \\
\hline Two-tail p & 0.79 & 0.79 & 0.69 & 0.52 & 0.06 & 0.08 \\
\hline $\mathrm{T}$ alpha half $95 \% \mathrm{CI}$ & 2.23 & 2.23 & 2.23 & 2.23 & 2.23 & 2.23 \\
\hline
\end{tabular}


Table 9. Results of paired sample t-tests of mean area, width, and depth at cross sections to determine significant differences between the before- and after-construction parameters at selected study sites in Alabama._Continued

[ $\Delta \mathrm{XS}$ area, difference between before- and after-construction cross-sectional areas; $\Delta$ top width, difference between before- and after-construction top widths; $\Delta$ mean depth, difference between before- and after-construction mean depths; $\mathrm{ft}^{2}$, square foot; $\mathrm{ft}$, foot; $\mathrm{n}$, sample size; Std dev; standard deviation; \%, percent; $\mathrm{CI}$, confidence interval. Null Hypothesis $\left(\mathrm{H}_{0}\right)$ : there is no significant difference between the means of the before- and after-construction cross-section indices. Alternate Hypothesis $\left(\mathrm{H}_{\mathrm{A}}\right)$ : there is a significant difference between the means of the before- and after-construction cross-section indices. $\mathrm{H}_{0}: \mu 0=0, \mathrm{H}_{\mathrm{A}}: \mu \mathrm{A} \neq 0$. Hypothesized mean difference: 0, Alpha $=0.05]$

\begin{tabular}{|c|c|c|c|c|c|c|}
\hline & \multicolumn{3}{|c|}{ Upstream } & \multicolumn{3}{|c|}{ Downstream } \\
\hline & $\begin{array}{c}\Delta X S \text { area } \\
\left(\mathrm{ft}^{2}\right)\end{array}$ & $\begin{array}{c}\Delta \text { Top width } \\
\text { (ft) }\end{array}$ & $\underset{\text { (ft) }}{\Delta \text { Mean depth }}$ & $\begin{array}{c}\Delta X S \text { area } \\
\left(\mathrm{ft}^{2}\right)\end{array}$ & $\begin{array}{c}\Delta \text { Top width } \\
\text { (ft) }\end{array}$ & $\begin{array}{c}\Delta \text { Mean depth } \\
\text { (ft) }\end{array}$ \\
\hline Lower 95\% CI & -15.44 & -2.46 & -0.35 & -20.70 & -5.64 & -0.05 \\
\hline Upper 95\% CI & 11.90 & 3.19 & 0.23 & 39.31 & 0.00 & 1.17 \\
\hline $\mathrm{n}$ & 11 & 11 & 11 & 11 & 11 & 11 \\
\hline Mean & 1.41 & 0.82 & -0.09 & -9.79 & -0.73 & -0.20 \\
\hline Std Dev & 6.99 & 2.52 & 0.31 & 18.18 & 2.38 & 0.27 \\
\hline t Stat & -0.64 & -1.03 & 0.90 & 1.70 & 0.97 & 2.38 \\
\hline Upper 95\% CI & 6.11 & 2.51 & 0.12 & 2.42 & 0.87 & -0.02 \\
\hline $\mathrm{H}_{0}$ or $\mathrm{H}_{\mathrm{A}}$ & $\mathrm{H}_{0}$ & $\mathrm{H}_{0}$ & $\mathrm{H}_{0}$ & $\mathrm{H}_{0}$ & $\mathrm{H}_{0}$ & $\mathrm{H}_{\mathrm{A}}$ \\
\hline \multicolumn{7}{|c|}{ Lye Branch, site 6} \\
\hline $\mathrm{n}$ & 11 & 11 & 11 & 10 & 10 & 10 \\
\hline Mean & 3.56 & -0.45 & 0.14 & -13.77 & 2.30 & -0.70 \\
\hline Std Dev & 28.22 & 6.10 & 0.59 & 34.45 & 5.64 & 0.80 \\
\hline t Stat & -0.40 & 0.24 & -0.76 & 1.20 & -1.22 & 2.62 \\
\hline Two-tail p & 0.70 & 0.82 & 0.47 & 0.26 & 0.25 & 0.03 \\
\hline $\mathrm{T}$ alpha half $95 \% \mathrm{CI}$ & 2.23 & 2.23 & 2.23 & 2.26 & 2.26 & 2.26 \\
\hline
\end{tabular}

sample bottle to be analyzed for that time step. Suspended sediment samples were analyzed by the USGS Kentucky Sediment Laboratory to determine suspended sediment concentrations (table 11; U.S. Geological Survey, 2020).

Concurrent with suspended sediment sampling, turbidity samples were collected in the main section of streamflow, away from eddies and the streambanks. Samples were transported to the Montgomery, Alabama, USGS laboratory for analysis. Samples were stored in a dark refrigerator for varying time periods (a few days to several months) between collection and analysis. Samples were gently inverted back and forth at least 20 times to resuspend particulate matter, and the turbidity values were measured in three separately analyzed aliquots by using a Hach 2100P turbidimeter. The median of the three measured concentrations was reported as the sample turbidity (table 11; U.S. Geological Survey, 2020).

The Techniques of Water-Resources Investigations of the U.S. Geological Survey, chapter A5, section 6.7 states "Turbidity measurement is time sensitive and therefore should be completed on-site (preferably in situ) to avoid effects from (a) biodegradation, growth, settling, or sorption of particulates in the sample; or (b) precipitation of humic acids and minerals (carbonates and hydroxides, for example) caused by changes in sample $\mathrm{pH}$ during transport and holding. If temporary storage of samples is necessary, collect samples in clean amber bottles, keep samples out of sunlight, and chilled at or below $4^{\circ} \mathrm{C}$ to prevent biodegradation of solids or biological growth. 
Table 10. Results of paired sample t-tests to determine the difference between the before- and after-construction thalweg slopes at selected study sites in Alabama.

[n, sample size; slope, thalweg slope; SE(reg), standard error of regression; SE(slope), standard error of slope; Difference(slope), difference in slopes; $\mathrm{SE}$ (Difference), standard error of difference in slopes; $\mathrm{t}$ stat, $\mathrm{t}$ statistic; df, degrees of freedom. Null Hypothesis $\left(\mathrm{H}_{0}\right)$ : there is no significant difference between the before- and after-construction thalweg slopes. Alternate Hypothesis $\left(\mathrm{H}_{\mathrm{A}}\right)$ : there is a significant difference between the before- and after-construction thalweg slopes. $\mathrm{H}_{0}: \mu 0=0, \mathrm{H}_{\mathrm{A}}: \mu \mathrm{A} \neq 0$. Hypothesized Mean Difference: 0, Alpha $\left.=0.05\right]$

\begin{tabular}{|c|c|c|c|c|}
\hline & \multicolumn{2}{|c|}{ Upstream thalweg slope } & \multicolumn{2}{|c|}{ Downstream thalweg slope } \\
\hline & Before construction & After construction & Before construction & After construction \\
\hline \multicolumn{5}{|c|}{ High Log Creek, site 1} \\
\hline Slope & -0.0007 & 0.0038 & -0.0012 & -0.0025 \\
\hline SE(reg) & 0.1685 & 0.9750 & 0.1063 & 0.2320 \\
\hline Difference(slope) & \multicolumn{2}{|c|}{0.0045} & \multicolumn{2}{|c|}{-0.0013} \\
\hline SE(Difference) & \multicolumn{2}{|c|}{0.0031} & \multicolumn{2}{|c|}{0.0008} \\
\hline t stat & \multicolumn{2}{|c|}{1.4566} & \multicolumn{2}{|c|}{1.4705} \\
\hline df & \multicolumn{2}{|c|}{17} & \multicolumn{2}{|c|}{17} \\
\hline Two-tail p & \multicolumn{2}{|c|}{0.1635} & \multicolumn{2}{|c|}{0.1597} \\
\hline
\end{tabular}

Tributary to Cahaba River, site 2

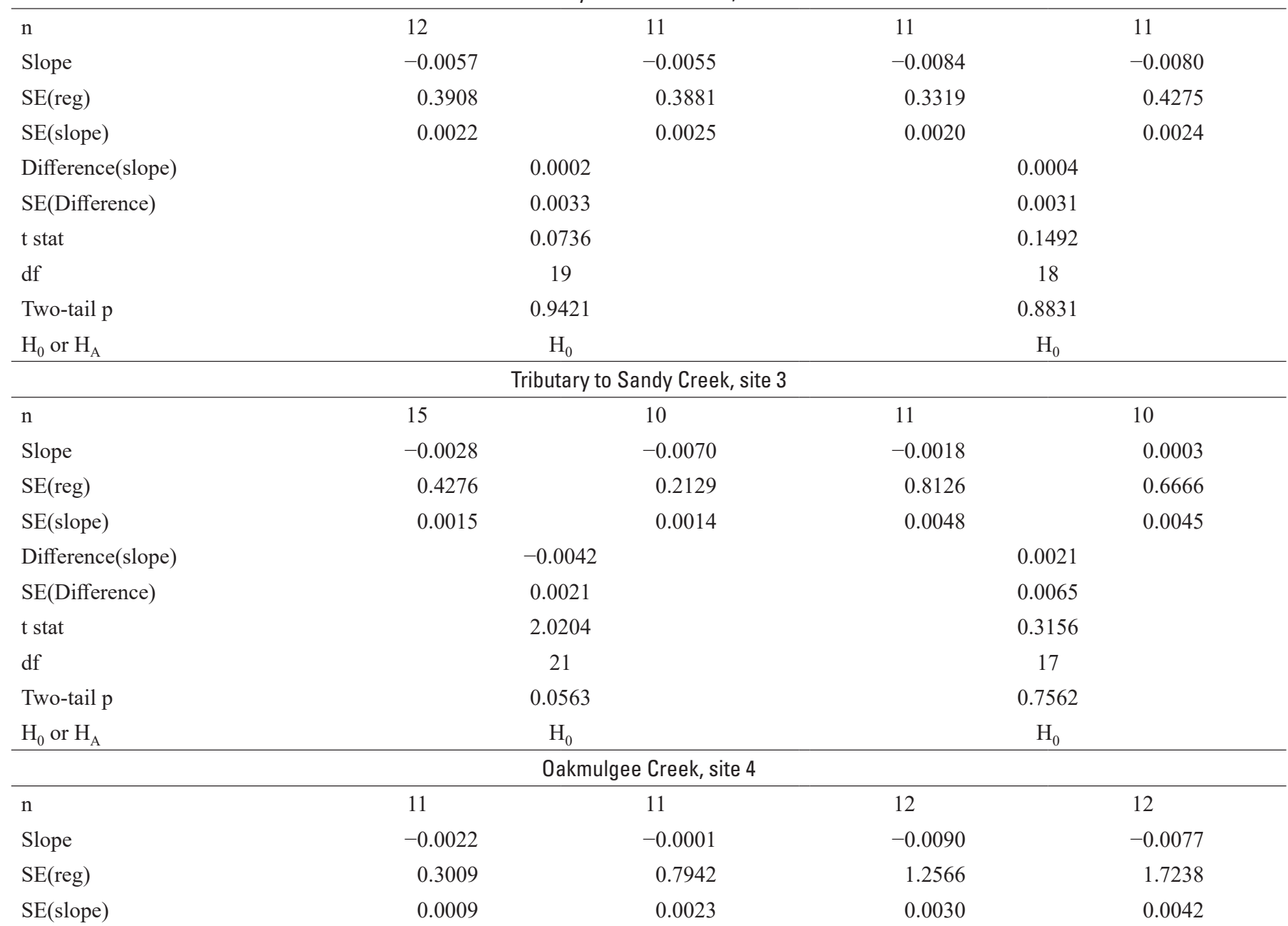


Table 10. Results of paired sample t-tests to determine the difference between the before- and after-construction thalweg slopes at selected study sites in Alabama._- Continued

[n, sample size; slope, thalweg slope; SE(reg), standard error of regression; SE(slope), standard error of slope; Difference(slope), difference in slopes; $\mathrm{SE}$ (Difference), standard error of difference in slopes; $t$ stat, $\mathrm{t}$ statistic; df, degrees of freedom. Null Hypothesis $\left(\mathrm{H}_{0}\right)$ : there is no significant difference between the before- and after-construction thalweg slopes. Alternate Hypothesis $\left(\mathrm{H}_{\mathrm{A}}\right)$ : there is a significant difference between the before- and after-construction thalweg slopes. $\mathrm{H}_{0}: \mu 0=0, \mathrm{H}_{\mathrm{A}}: \mu \mathrm{A} \neq 0$. Hypothesized Mean Difference: 0, Alpha $\left.=0.05\right]$

\begin{tabular}{|c|c|c|c|c|}
\hline & \multicolumn{2}{|c|}{ Upstream thalweg slope } & \multicolumn{2}{|c|}{ Downstream thalweg slope } \\
\hline & Before construction & After construction & Before construction & After construction \\
\hline \multicolumn{5}{|c|}{ Oakmulgee Creek, site 4-Continued } \\
\hline Difference(slope) & \multicolumn{2}{|c|}{0.0021} & \multicolumn{2}{|c|}{0.0013} \\
\hline $\mathrm{SE}$ (Difference) & \multicolumn{2}{|c|}{0.0025} & \multicolumn{2}{|c|}{0.0052} \\
\hline t stat & \multicolumn{2}{|c|}{0.8299} & \multicolumn{2}{|c|}{0.2577} \\
\hline df & \multicolumn{2}{|c|}{18} & \multicolumn{2}{|c|}{20} \\
\hline Two-tail p & \multicolumn{2}{|c|}{0.4175} & \multicolumn{2}{|c|}{0.7993} \\
\hline $\mathrm{H}_{0}$ or $\mathrm{H}_{\mathrm{A}}$ & \multicolumn{2}{|c|}{$\mathrm{H}_{0}$} & \multicolumn{2}{|c|}{$\mathrm{H}_{0}$} \\
\hline \multicolumn{5}{|c|}{ Northington Branch, site 5} \\
\hline $\mathrm{n}$ & 11 & 11 & 11 & 11 \\
\hline Slope & 0.0006 & -0.0022 & -0.0023 & -0.0021 \\
\hline SE(reg) & 0.4310 & 0.2842 & 0.3905 & 0.4203 \\
\hline SE(slope) & 0.0015 & 0.0010 & 0.0014 & 0.0015 \\
\hline Difference(slope) & \multicolumn{2}{|c|}{-0.0028} & \multicolumn{2}{|c|}{0.0002} \\
\hline SE(Difference) & \multicolumn{2}{|c|}{0.0018} & \multicolumn{2}{|c|}{0.0020} \\
\hline $\mathrm{t}$ stat & \multicolumn{2}{|c|}{1.5219} & \multicolumn{2}{|c|}{0.0807} \\
\hline df & \multicolumn{2}{|c|}{18} & \multicolumn{2}{|c|}{18} \\
\hline Two-tail p & \multicolumn{2}{|c|}{0.1454} & \multicolumn{2}{|c|}{0.9366} \\
\hline $\mathrm{H}_{0}$ or $\mathrm{H}_{\mathrm{A}}$ & \multicolumn{2}{|c|}{$\mathrm{H}_{0}$} & \multicolumn{2}{|c|}{$\mathrm{H}_{0}$} \\
\hline \multicolumn{5}{|c|}{ Lye Branch, site 6} \\
\hline $\mathrm{n}$ & 11 & 11 & 11 & 10 \\
\hline Slope & -0.0029 & 0.0014 & 0.0004 & -0.0046 \\
\hline SE(reg) & 0.3483 & 0.1976 & 1.1609 & 0.3138 \\
\hline SE(slope) & 0.0012 & 0.0007 & 0.0041 & 0.0012 \\
\hline Difference(slope) & \multicolumn{2}{|c|}{0.0044} & \multicolumn{2}{|c|}{-0.0050} \\
\hline SE(Difference) & & & & \\
\hline t stat & & & & \\
\hline df & & & & \\
\hline Two-tail p & & & & \\
\hline $\mathrm{H}_{0}$ or $\mathrm{H}_{\mathrm{A}}$ & & & & \\
\hline
\end{tabular}

The holding time must not exceed 24 hours" (Anderson, 2005, p. 33). The samples collected for this study did not strictly follow the prescribed methods as described in that samples were not analyzed within 24 hours of collection.

Ratios of the paired upstream to downstream suspended sediment concentrations and turbidity values were examined for each study reach by culvert construction phases (table 12). Ratios of upstream to downstream sediment concentrations and turbidity show differences as deviations from 1.00. For the purposes of this study, ratio values of 1.00, plus or minus $0.10(0.90-1.10)$ were considered equal. Ratio values greater than 1.10 indicate the downstream sediment measurement was larger, and conversely, ratio values less than 0.90 indicate the upstream sediment measurement was larger. If a culvert had little effect on sediment transport, sediment concentrations and turbidity were expected to be unchanged from upstream to downstream. 


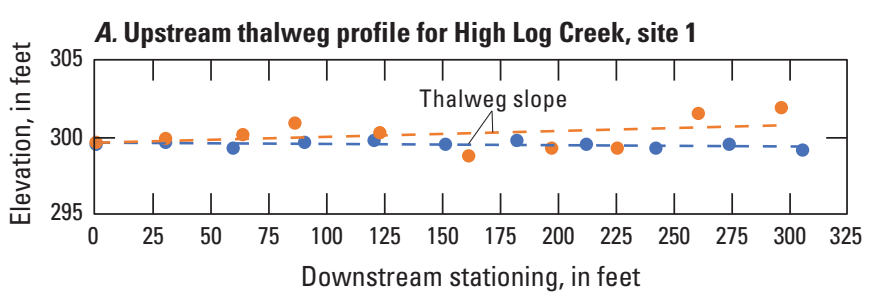

EXPLANATION

- Before construction (2010)

- After construction (2018)

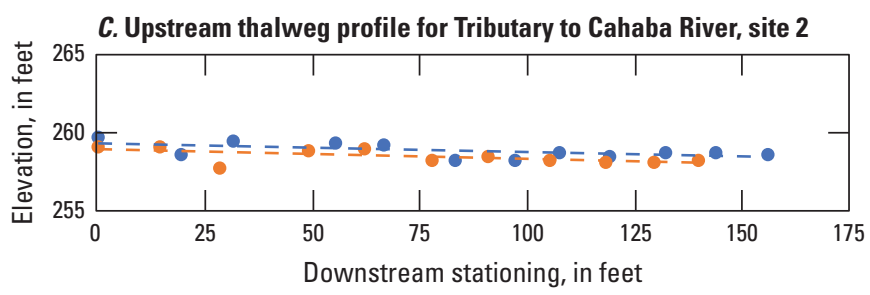

EXPLANATION

- Before construction (2010)

- After construction (2016)

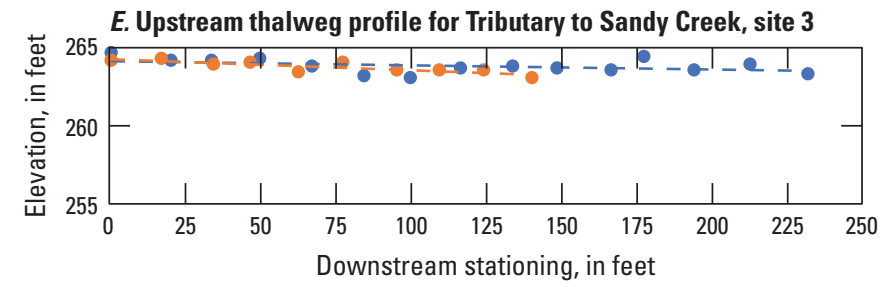

EXPLANATION

- Before construction (2010)

- After construction (2016)
B. Downstream thalweg profile for High Log Creek, site 1

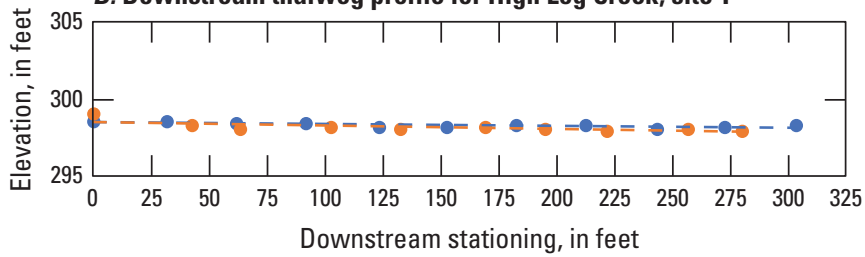

EXPLANATION

- Before construction (2010)

- After construction (2018)

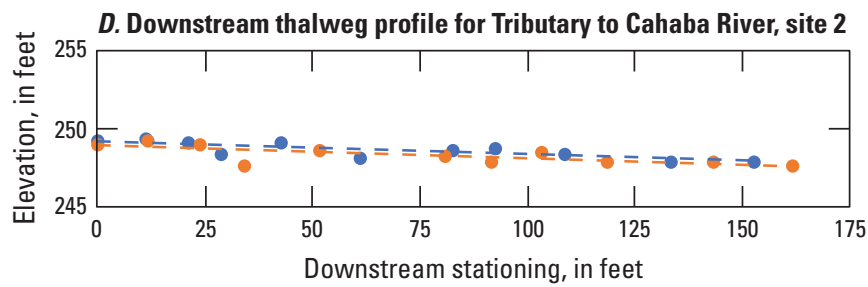

EXPLANATION

- Before construction (2010)

- After construction (2016)

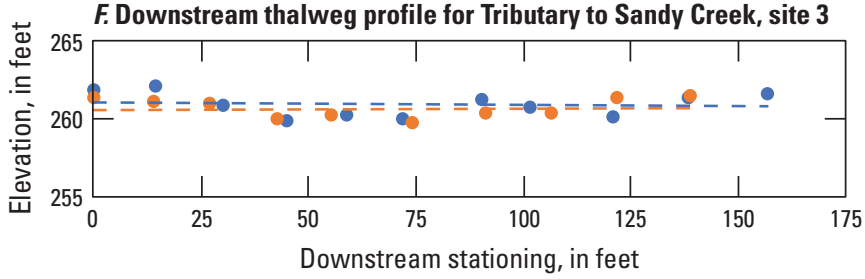

EXPLANATION

- Before construction (2010)

- After construction (2016)

Figure 4. Longitudinal profiles of before- and after-construction thalwegs, upstream and downstream of selected study sites in Alabama. 


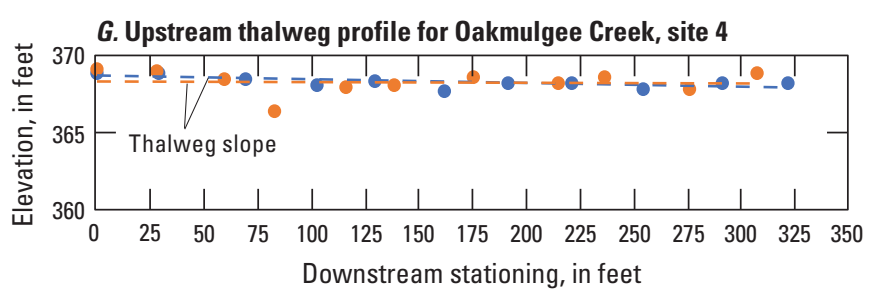

EXPLANATION

- Before construction (2010)

- After construction (2016)

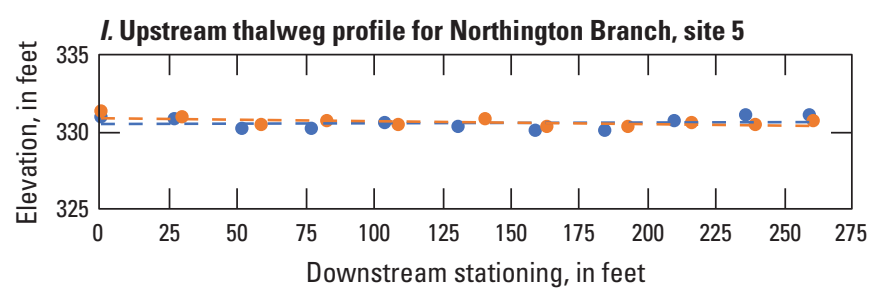

EXPLANATION

- Before construction (2011)

- After construction (2015)

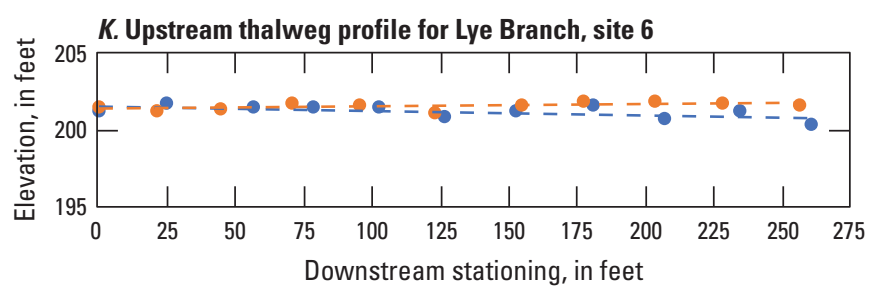

EXPLANATION

- Before construction (2011)

- After construction (2016)

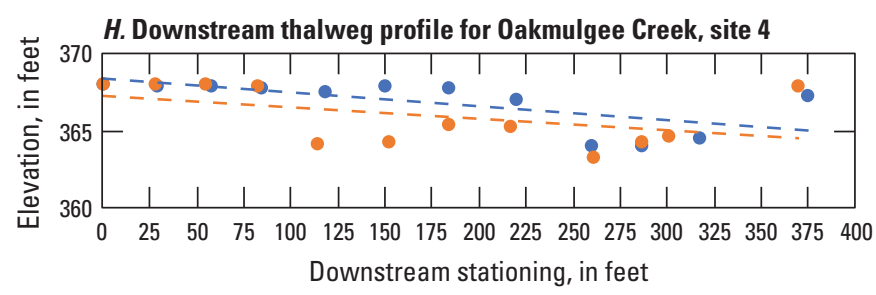

EXPLANATION

- Before construction (2010)

- After construction (2016)

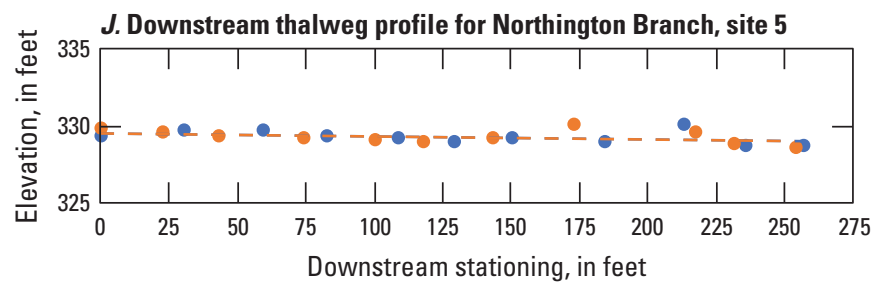

EXPLANATION

- Before construction (2011)

- After construction (2015)

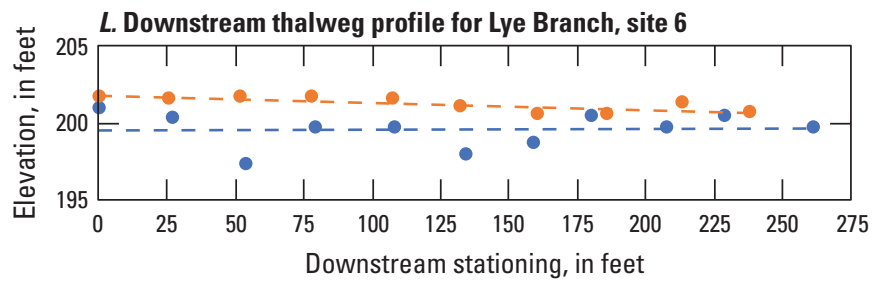

EXPLANATION

- Before construction (2011)

- After construction (2016)

Figure 4. Longitudinal profiles of before- and after-construction thalwegs, upstream and downstream of selected study sites in Alabama.-Continued

\section{Streamflow Measurements}

Stormflows measured as a part of this study varied considerably. To help determine if samples for sediment analysis were collected during similar flow conditions in each of the three construction phases, the maximum measured streamflow, the change in stage, and the storm duration for each event were summarized by site and storm date (table 13). Streamflow measurements were made upstream and downstream of culvert locations during each of the culvert construction phases at each site during multiple storm runoff events. Streamflow measurements were made by using prescribed methods as described in Turnipseed and Sauer (2010). These streamflow values are available through the USGS National Water Information System (U.S. Geological Survey, 2020). Stage-streamflow relations (rating tables) were not developed for any of the selected study reaches because of the limited number of streamflow measurements. 
Table 11. Ratios of paired upstream to downstream suspended sediment concentrations and turbidity values collected during storm events measured before, during, and after construction at selected study sites in Alabama.

[mg/L, milligrams per liter; NTRU, Nephelometric Turbidity Ratio Units; BC, before construction; DC, during construction; AC, after construction; dates are in month/day/year format; ratios less than 0.9 indicate downstream values are greater; ratios between 0.9 and 1.1 indicate nearly equal values; ratios greater than 1.1 indicate upstream values are greater; --, no data]

\begin{tabular}{|c|c|c|c|c|c|c|c|c|c|}
\hline \multirow[b]{2}{*}{$\begin{array}{c}\text { Construction } \\
\text { phase }\end{array}$} & \multirow[b]{2}{*}{$\begin{array}{c}\text { Date of sample } \\
\text { collection }\end{array}$} & \multirow[b]{2}{*}{$\begin{array}{l}\text { Time of } \\
\text { sample } \\
\text { collection }\end{array}$} & \multirow[b]{2}{*}{$\begin{array}{l}\text { Limb of storm } \\
\text { hydrograph }\end{array}$} & \multicolumn{2}{|c|}{ Upstream of culvert } & \multicolumn{2}{|c|}{ Downstream of culvert } & \multirow{2}{*}{$\begin{array}{l}\text { Ratio of upstream } \\
\text { to downstream } \\
\text { suspended sediment } \\
\text { concentrations }\end{array}$} & \multirow{2}{*}{$\begin{array}{c}\text { Ratio of upstream } \\
\text { to downstream } \\
\text { turbidity values }\end{array}$} \\
\hline & & & & $\begin{array}{c}\text { Suspended sediment } \\
\text { concentration } \\
(\mathrm{mg} / \mathrm{L})\end{array}$ & $\begin{array}{l}\text { Turbidity } \\
\text { (NTRU) }\end{array}$ & $\begin{array}{c}\text { Suspended sediment } \\
\text { concentration } \\
(\mathrm{mg} / \mathrm{L})\end{array}$ & $\begin{array}{c}\text { Turbidity } \\
\text { (NTRU) }\end{array}$ & & \\
\hline \multicolumn{10}{|c|}{ High Log Creek, site 1} \\
\hline $\mathrm{BC}$ & $7 / 15 / 2011$ & 2315 & Peak & 1,580 & 470 & 1,540 & 180 & 1.03 & 2.61 \\
\hline $\mathrm{BC}$ & $7 / 16 / 2011$ & 0010 & Falling & 1,880 & 610 & 1,950 & 620 & 0.96 & 0.98 \\
\hline $\mathrm{BC}$ & $2 / 25 / 2013$ & 1135 & Rising & 343 & 56 & 481 & 61 & 0.71 & 0.92 \\
\hline $\mathrm{BC}$ & $2 / 25 / 2013$ & 1215 & Rising & 474 & 66 & 453 & 79 & 1.05 & 0.84 \\
\hline $\mathrm{BC}$ & $2 / 25 / 2013$ & 1500 & Rising & 548 & 100 & 503 & 140 & 1.09 & 0.71 \\
\hline $\mathrm{DC}$ & $4 / 15 / 2014$ & 0630 & Peak? & 784 & 250 & 748 & 250 & 1.05 & 1.00 \\
\hline DC & $4 / 15 / 2014$ & 0805 & Falling & 626 & 210 & 587 & 220 & 1.07 & 0.95 \\
\hline DC & $4 / 15 / 2014$ & 0930 & Falling & 487 & 190 & 1,010 & 190 & 0.48 & 1.00 \\
\hline $\mathrm{DC}$ & $5 / 26 / 2015$ & 1740 & Rising & 215 & 54 & 136 & 89 & 1.58 & 0.61 \\
\hline $\mathrm{DC}$ & $5 / 26 / 2015$ & 1835 & Rising & 2,360 & 270 & 2,610 & 140 & 0.90 & 1.93 \\
\hline $\mathrm{AC}$ & 2/7/2018 & 1450 & Rising & 70 & 63 & 67 & 58 & 1.04 & 1.09 \\
\hline $\mathrm{AC}$ & $2 / 7 / 2018$ & 1605 & Falling & 83 & 47 & 71 & 72 & 1.17 & 0.65 \\
\hline $\mathrm{AC}$ & $3 / 6 / 2018$ & 1630 & Falling & 221 & 150 & 370 & 140 & 0.60 & 1.07 \\
\hline $\mathrm{AC}$ & $10 / 10 / 2018$ & 1910 & Rising & 345 & 360 & 528 & 300 & 0.65 & 1.20 \\
\hline $\mathrm{AC}$ & $10 / 10 / 2018$ & 2020 & Rising & 285 & 240 & 268 & 260 & 1.06 & 0.92 \\
\hline $\mathrm{AC}$ & $10 / 10 / 2018$ & 2220 & Rising & 679 & 310 & 597 & 320 & 1.14 & 0.97 \\
\hline $\mathrm{AC}$ & $10 / 10 / 2018$ & 2335 & Rising & 1,100 & 570 & 1,010 & 560 & 1.09 & 1.02 \\
\hline \multicolumn{10}{|c|}{ Tributary to Cahaba, site 2} \\
\hline $\mathrm{DC}$ & $4 / 4 / 2011$ & 2125 & Rising & 93 & 57 & 604 & 910 & 0.15 & 0.06 \\
\hline $\mathrm{DC}$ & $4 / 4 / 2011$ & 2216 & Peak? & 48 & 55 & 280 & 320 & 0.17 & 0.17 \\
\hline DC & $4 / 4 / 2011$ & 2317 & Peak? & 38 & 39 & 100 & 91 & 0.38 & 0.43 \\
\hline $\mathrm{DC}$ & $4 / 5 / 2011$ & 0050 & Falling & 29 & 49 & 61 & 82 & 0.48 & 0.60 \\
\hline $\mathrm{AC}$ & $12 / 8 / 2018$ & 1645 & $\begin{array}{l}\text { Falling, from } \\
\text { previous } \\
\text { peak }\end{array}$ & 77 & 48 & 61 & 53 & 1.26 & 0.91 \\
\hline $\mathrm{AC}$ & $12 / 8 / 2018$ & 1910 & Falling & 909 & 89 & 288 & 110 & 3.16 & 0.81 \\
\hline $\mathrm{AC}$ & $4 / 18 / 2019$ & 2235 & Falling & 240 & 54 & 52 & 58 & 4.62 & 0.93 \\
\hline
\end{tabular}


Table 11. Ratios of paired upstream to downstream suspended sediment concentrations and turbidity values collected during storm events measured before, during, and after construction at selected study sites in Alabama.-Continued

[mg/L, milligrams per liter; NTRU, Nephelometric Turbidity Ratio Units; BC, before construction; DC, during construction; AC, after construction; dates are in month/day/year format; ratios less than 0.9 indicate downstream values are greater; ratios between 0.9 and 1.1 indicate nearly equal values; ratios greater than 1.1 indicate upstream values are greater; --, no data]

\begin{tabular}{|c|c|c|c|c|c|c|c|c|c|}
\hline \multirow[b]{2}{*}{$\begin{array}{c}\text { Construction } \\
\text { phase }\end{array}$} & \multirow[b]{2}{*}{$\begin{array}{l}\text { Date of sample } \\
\text { collection }\end{array}$} & \multirow[b]{2}{*}{$\begin{array}{c}\text { Time of } \\
\text { sample } \\
\text { collection }\end{array}$} & \multirow[b]{2}{*}{$\begin{array}{l}\text { Limb of storm } \\
\text { hydrograph }\end{array}$} & \multicolumn{2}{|c|}{ Upstream of culvert } & \multicolumn{2}{|c|}{ Downstream of culvert } & \multirow{2}{*}{$\begin{array}{l}\text { Ratio of upstream } \\
\text { to downstream } \\
\text { suspended sediment } \\
\text { concentrations }\end{array}$} & \multirow[b]{2}{*}{$\begin{array}{c}\text { Ratio of upstream } \\
\text { to downstream } \\
\text { turbidity values }\end{array}$} \\
\hline & & & & $\begin{array}{c}\text { Suspended sediment } \\
\text { concentration } \\
(\mathrm{mg} / \mathrm{L})\end{array}$ & $\begin{array}{l}\text { Turbidity } \\
\text { (NTRU) }\end{array}$ & $\begin{array}{c}\text { Suspended sediment } \\
\text { concentration } \\
(\mathrm{mg} / \mathrm{L})\end{array}$ & $\begin{array}{c}\text { Turbidity } \\
\text { (NTRU) }\end{array}$ & & \\
\hline \multicolumn{10}{|c|}{ Tributary to Cahaba, site 2-Continued } \\
\hline $\mathrm{AC}$ & $4 / 18 / 2019$ & 2315 & Rising & 46 & 51 & 37 & 49 & 1.24 & 1.04 \\
\hline $\mathrm{AC}$ & $4 / 19 / 2019$ & 0015 & Peak & 191 & 94 & 266 & 84 & 0.72 & 1.12 \\
\hline $\mathrm{AC}$ & $4 / 19 / 2019$ & 0055 & Falling & 169 & 110 & 177 & 100 & 0.95 & 1.10 \\
\hline $\mathrm{AC}$ & $4 / 19 / 2019$ & 0140 & Falling & 93 & 86 & 105 & 96 & 0.89 & 0.896 \\
\hline \multicolumn{10}{|c|}{ Tributary to Sandy Creek, site 3} \\
\hline $\mathrm{DC}$ & $1 / 30 / 2013$ & 0940 & Rising & 109 & 96 & 157 & 210 & 0.69 & 0.46 \\
\hline $\mathrm{DC}$ & $1 / 30 / 2013$ & 1012 & Peak & 147 & 94 & 120 & 170 & 1.23 & 0.55 \\
\hline DC & $1 / 30 / 2013$ & 1047 & Falling & 178 & 180 & 107 & 130 & 1.66 & 1.38 \\
\hline $\mathrm{AC}$ & $12 / 8 / 2018$ & 1725 & Rising & 119 & 42 & 250 & 27 & 0.48 & 1.56 \\
\hline $\mathrm{AC}$ & $12 / 8 / 2018$ & 1900 & Rising & 44 & 47 & 125 & 28 & 0.35 & 1.68 \\
\hline $\mathrm{AC}$ & $12 / 8 / 2018$ & 1935 & Rising & 57 & 56 & 137 & 36 & 0.42 & 1.56 \\
\hline $\mathrm{AC}$ & $12 / 8 / 2018$ & 2020 & Rising & 70 & 66 & 172 & 40 & 0.41 & 1.65 \\
\hline $\mathrm{AC}$ & $12 / 8 / 2018$ & 2145 & Peak & 87 & 99 & 81 & 53 & 1.07 & 1.87 \\
\hline $\mathrm{AC}$ & $4 / 18 / 2019$ & 2150 & Falling & -- & 120 & 98 & 92 & -- & 1.30 \\
\hline $\mathrm{AC}$ & $4 / 18 / 2019$ & 2245 & Falling & 101 & 88 & 126 & 83 & 0.80 & 1.06 \\
\hline $\mathrm{AC}$ & $4 / 19 / 2019$ & 0039 & Rising & 75 & 56 & 75 & 72 & 1.00 & 0.78 \\
\hline $\mathrm{AC}$ & $4 / 19 / 2019$ & 0130 & Peak & 51 & 54 & 77 & 60 & 0.66 & 0.90 \\
\hline \multicolumn{10}{|c|}{ Oakmulgee Creek, site 4} \\
\hline $\mathrm{BC}$ & $3 / 30 / 2011$ & 2015 & Rising & 230 & 110 & 181 & 91 & 1.27 & 1.21 \\
\hline $\mathrm{BC}$ & $3 / 30 / 2011$ & 2230 & Peak & 149 & 83 & 222 & 99 & 0.67 & 0.84 \\
\hline $\mathrm{BC}$ & $3 / 31 / 2011$ & 0130 & Falling & 127 & 62 & 109 & 66 & 1.17 & 0.94 \\
\hline $\mathrm{BC}$ & $7 / 31 / 2012$ & 1000 & Rising & 938 & 540 & 934 & 550 & 1.00 & 0.98 \\
\hline $\mathrm{BC}$ & $7 / 31 / 2012$ & 1045 & Peak? & 2,000 & 440 & 749 & 430 & 2.67 & 1.02 \\
\hline $\mathrm{DC}$ & $4 / 6 / 2014$ & 1905 & Rising & 383 & 130 & 220 & 110 & 1.74 & 1.18 \\
\hline DC & 4/6/2014 & 2040 & Rising? & 811 & 200 & 240 & 110 & 3.38 & 1.82 \\
\hline DC & $9 / 15 / 2014$ & 1920 & Rising & 362 & 240 & 292 & 220 & 1.24 & 1.09 \\
\hline $\mathrm{DC}$ & $9 / 15 / 2014$ & 2030 & Falling & 347 & 350 & 331 & 280 & 1.05 & 1.25 \\
\hline
\end{tabular}


Table 11. Ratios of paired upstream to downstream suspended sediment concentrations and turbidity values collected during storm events measured before, during, and after construction at selected study sites in Alabama.-Continued

[mg/L, milligrams per liter; NTRU, Nephelometric Turbidity Ratio Units; BC, before construction; DC, during construction; AC, after construction; dates are in month/day/year format; ratios less than 0.9 indicate downstream values are greater; ratios between 0.9 and 1.1 indicate nearly equal values; ratios greater than 1.1 indicate upstream values are greater; --, no data]

\begin{tabular}{|c|c|c|c|c|c|c|c|c|c|}
\hline \multirow[b]{2}{*}{$\begin{array}{c}\text { Construction } \\
\text { phase }\end{array}$} & \multirow[b]{2}{*}{$\begin{array}{l}\text { Date of sample } \\
\text { collection }\end{array}$} & \multirow[b]{2}{*}{$\begin{array}{l}\text { Time of } \\
\text { sample } \\
\text { collection }\end{array}$} & \multirow[b]{2}{*}{$\begin{array}{l}\text { Limb of storm } \\
\text { hydrograph }\end{array}$} & \multicolumn{2}{|c|}{ Upstream of culvert } & \multicolumn{2}{|c|}{ Downstream of culvert } & \multirow{2}{*}{$\begin{array}{l}\text { Ratio of upstream } \\
\text { to downstream } \\
\text { suspended sediment } \\
\text { concentrations }\end{array}$} & \multirow[b]{2}{*}{$\begin{array}{l}\text { Ratio of upstream } \\
\text { to downstream } \\
\text { turbidity values }\end{array}$} \\
\hline & & & & $\begin{array}{l}\text { Suspended sediment } \\
\text { concentration } \\
(\mathrm{mg} / \mathrm{L})\end{array}$ & $\begin{array}{l}\text { Turbidity } \\
\text { (NTRU) }\end{array}$ & $\begin{array}{l}\text { Suspended sediment } \\
\text { concentration } \\
(\mathrm{mg} / \mathrm{L})\end{array}$ & $\begin{array}{l}\text { Turbidity } \\
\text { (NTRU) }\end{array}$ & & \\
\hline \multicolumn{10}{|c|}{ Oakmulgee Creek, site 4-Continued } \\
\hline DC & $10 / 14 / 2014$ & 0021 & Rising & 1,540 & 480 & 1,010 & 710 & 1.52 & 0.68 \\
\hline $\mathrm{AC}$ & $3 / 8 / 2017$ & 0045 & $\begin{array}{l}\text { Falling, near } \\
\text { peak }\end{array}$ & 405 & 190 & 638 & 180 & 0.63 & 1.06 \\
\hline $\mathrm{AC}$ & $4 / 3 / 2017$ & 1100 & Rising & 512 & 250 & 698 & 200 & 0.73 & 1.25 \\
\hline $\mathrm{AC}$ & $4 / 3 / 2017$ & 1155 & Peak? & 583 & 240 & 476 & 220 & 1.22 & 1.09 \\
\hline $\mathrm{AC}$ & $4 / 27 / 2017$ & 1105 & Falling & 53 & 38 & 52 & 38 & 1.02 & 1.00 \\
\hline \multicolumn{10}{|c|}{ Northington Branch, site 5} \\
\hline $\mathrm{BC}$ & 9/5/2011 & 1020 & Rising & 331 & -- & 1,870 & -- & 0.18 & -- \\
\hline $\mathrm{BC}$ & 9/5/2011 & 1110 & Rising & 288 & 200 & 561 & 250 & 0.51 & 0.80 \\
\hline $\mathrm{BC}$ & $9 / 5 / 2011$ & 1335 & Peak & 193 & 160 & 361 & 180 & 0.53 & 0.89 \\
\hline $\mathrm{AC}$ & $4 / 10 / 2015$ & 0745 & Rising & 57 & 46 & 75 & 55 & 0.76 & 0.84 \\
\hline $\mathrm{AC}$ & $4 / 10 / 2015$ & 0930 & Rising & 121 & 150 & 116 & 130 & 1.04 & 1.15 \\
\hline $\mathrm{AC}$ & $4 / 10 / 2015$ & 1035 & Peak & 102 & 100 & 98 & 110 & 1.04 & 0.91 \\
\hline $\mathrm{AC}$ & $4 / 10 / 2015$ & 1140 & Falling & 89 & 110 & 98 & 110 & 0.91 & 1.00 \\
\hline $\mathrm{AC}$ & $11 / 18 / 2015$ & 0800 & Rising & 153 & 130 & 415 & 390 & 0.37 & 0.33 \\
\hline $\mathrm{AC}$ & $11 / 18 / 2015$ & 0930 & Rising & 200 & 140 & -- & 22 & -- & 6.36 \\
\hline $\mathrm{AC}$ & $11 / 18 / 2015$ & 1115 & Peak & 250 & 190 & 234 & 180 & 1.07 & 1.06 \\
\hline $\mathrm{AC}$ & $2 / 23 / 2016$ & 2205 & Rising & 168 & 40 & 342 & 86 & 0.49 & 0.47 \\
\hline $\mathrm{AC}$ & $2 / 23 / 2016$ & 2300 & Rising & 410 & 70 & 705 & 180 & 0.58 & 0.39 \\
\hline $\mathrm{AC}$ & $2 / 24 / 2016$ & 0025 & Peak & 574 & 310 & 581 & 250 & 0.99 & 1.24 \\
\hline $\mathrm{AC}$ & $2 / 24 / 2016$ & 0120 & Falling & -- & 140 & 378 & 150 & -- & 0.93 \\
\hline \multicolumn{10}{|c|}{ Lye Branch, site 6} \\
\hline $\mathrm{BC}$ & $4 / 15 / 2011$ & 2145 & Peak & 385 & 230 & 376 & 230 & 1.02 & 1.00 \\
\hline $\mathrm{BC}$ & $4 / 15 / 2011$ & 2325 & Falling & 217 & 180 & 225 & 160 & 0.96 & 1.13 \\
\hline $\mathrm{BC}$ & $12 / 20 / 2012$ & 1115 & Rising & 93 & 53 & 85 & 41 & 1.09 & 1.29 \\
\hline $\mathrm{BC}$ & $12 / 20 / 2012$ & 1210 & Rising & 112 & 44 & 89 & 40 & 1.26 & 1.10 \\
\hline $\mathrm{DC}$ & $1 / 13 / 2014$ & 1520 & Rising & 217 & 6.3 & 99 & 8.3 & 2.19 & 0.76 \\
\hline
\end{tabular}


Table 11. Ratios of paired upstream to downstream suspended sediment concentrations and turbidity values collected during storm events measured before, during, and after construction at selected study sites in Alabama.-Continued

[mg/L, milligrams per liter; NTRU, Nephelometric Turbidity Ratio Units; BC, before construction; DC, during construction; AC, after construction; dates are in month/day/year format; ratios less than 0.9 indicate downstream values are greater; ratios between 0.9 and 1.1 indicate nearly equal values; ratios greater than 1.1 indicate upstream values are greater; --, no data]

\begin{tabular}{|c|c|c|c|c|c|c|c|c|c|}
\hline \multirow[b]{2}{*}{$\begin{array}{c}\text { Construction } \\
\text { phase }\end{array}$} & \multirow[b]{2}{*}{$\begin{array}{l}\text { Date of sample } \\
\text { collection }\end{array}$} & \multirow[b]{2}{*}{$\begin{array}{l}\text { Time of } \\
\text { sample } \\
\text { collection }\end{array}$} & \multirow[b]{2}{*}{$\begin{array}{l}\text { Limb of storm } \\
\text { hydrograph }\end{array}$} & \multicolumn{2}{|c|}{ Upstream of culvert } & \multicolumn{2}{|c|}{ Downstream of culvert } & \multirow{2}{*}{$\begin{array}{l}\text { Ratio of upstream } \\
\text { to downstream } \\
\text { suspended sediment } \\
\text { concentrations }\end{array}$} & \multirow[b]{2}{*}{$\begin{array}{l}\text { Ratio of upstream } \\
\text { to downstream } \\
\text { turbidity values }\end{array}$} \\
\hline & & & & $\begin{array}{c}\text { Suspended sediment } \\
\text { concentration } \\
\text { (mg/L) }\end{array}$ & $\begin{array}{l}\text { Turbidity } \\
\text { (NTRU) }\end{array}$ & $\begin{array}{c}\text { Suspended sediment } \\
\text { concentration } \\
\text { (mg/L) }\end{array}$ & $\begin{array}{l}\text { Turbidity } \\
\text { (NTRU) }\end{array}$ & & \\
\hline \multicolumn{10}{|c|}{ Lye Branch, site 6-Continued } \\
\hline $\mathrm{DC}$ & $1 / 13 / 2014$ & 1612 & Rising & 41 & 6.5 & 74 & 8.7 & 0.55 & 0.75 \\
\hline $\mathrm{DC}$ & $1 / 13 / 2014$ & 1710 & Rising & 54 & 8.1 & 17 & 7.8 & 3.18 & 1.04 \\
\hline $\mathrm{DC}$ & $1 / 13 / 2014$ & 1805 & Peak & 20 & 7.8 & 181 & 11 & 0.11 & 0.71 \\
\hline $\mathrm{DC}$ & $2 / 21 / 2014$ & 1652 & Rising & 440 & 110 & 462 & 140 & 0.95 & 0.79 \\
\hline $\mathrm{DC}$ & $4 / 6 / 2014$ & 2358 & Rising & 267 & 110 & 255 & 100 & 1.05 & 1.10 \\
\hline $\mathrm{DC}$ & $4 / 7 / 2014$ & 0035 & Rising & 277 & -- & 314 & 160 & 0.88 & -- \\
\hline $\mathrm{AC}$ & $3 / 7 / 2017$ & 1910 & Rising & 378 & 150 & 266 & 150 & 1.42 & 1.00 \\
\hline $\mathrm{AC}$ & $3 / 7 / 2017$ & 2100 & Rising & 1,220 & 270 & 509 & 270 & 2.40 & 1.00 \\
\hline $\mathrm{AC}$ & $3 / 7 / 2017$ & 2235 & Peak & 461 & 250 & 404 & 250 & 1.14 & 1.00 \\
\hline $\mathrm{AC}$ & $6 / 21 / 2017$ & 1845 & Rising & 159 & 89 & 168 & 87 & 0.95 & 1.02 \\
\hline $\mathrm{AC}$ & $6 / 21 / 2017$ & 1945 & Rising & 171 & 85 & 166 & 85 & 1.03 & 1.00 \\
\hline $\mathrm{AC}$ & $6 / 21 / 2017$ & 2045 & Peak & 166 & 91 & 181 & 100 & 0.92 & 0.91 \\
\hline $\mathrm{AC}$ & $8 / 8 / 2017$ & 1828 & Rising & 720 & 310 & 574 & 260 & 1.25 & 1.19 \\
\hline
\end{tabular}


Table 12. Analysis of ratios of paired upstream to downstream suspended sediment concentrations and turbidity values measured before, during, and after construction at selected study sites in Alabama.

$[\mathrm{BC}$, before construction; DC, during construction; $\mathrm{AC}$, after construction; $<$, less than; $\mathrm{n}<0.9$ indicates downstream values are greater than upstream values; $0.9<\mathrm{n}<1.1$ indicates nearly equal values; $>$, greater than; $>1.1$ indicates upstream values are greater than downstream values; $n$, number of sample pairs; --, no data]

\begin{tabular}{|c|c|c|c|c|c|c|c|c|c|c|c|c|c|c|c|}
\hline \multirow{2}{*}{$\begin{array}{c}\text { Abbreviated site } \\
\text { name and site number }\end{array}$} & \multicolumn{5}{|c|}{ BC } & \multicolumn{5}{|c|}{ DC } & \multicolumn{5}{|c|}{ AC } \\
\hline & $\mathbf{n}$ & Mean & $\mathrm{n}<0.9$ & $0.9<n<1.1$ & $\mathrm{n}>1.1$ & $\mathbf{n}$ & Mean & $\mathrm{n}<0.9$ & $0.9<n<1.1$ & $\mathrm{n}>1.1$ & $\mathbf{n}$ & Mean & $\mathrm{n}<0.9$ & $0.9<n<1.1$ & $\mathrm{n}>1.1$ \\
\hline \multicolumn{16}{|c|}{ Ratio of upstream to downstream suspended sediment concentrations } \\
\hline High Log Creek, site 1 & 5 & 0.97 & 1 & 4 & 0 & 5 & 1.02 & 1 & 3 & 1 & 7 & 0.96 & 2 & 4 & 1 \\
\hline $\begin{array}{l}\text { Tributary to Cahaba River, } \\
\text { site } 2\end{array}$ & -- & -- & -- & -- & -- & 4 & 0.30 & 4 & 0 & 0 & 7 & 1.83 & 2 & 1 & 4 \\
\hline $\begin{array}{l}\text { Tributary to Sandy Creek, } \\
\text { site } 3\end{array}$ & -- & -- & -- & -- & -- & 3 & 1.19 & 1 & 0 & 2 & 8 & 0.65 & 6 & 2 & 0 \\
\hline Oakmulgee Creek, site 4 & 5 & 1.36 & 1 & 1 & 3 & 5 & 1.79 & 0 & 1 & 4 & 4 & 0.90 & 2 & 1 & 1 \\
\hline Northington Branch, site 5 & 3 & 0.41 & 3 & 0 & 0 & -- & -- & -- & -- & -- & 9 & 0.81 & 4 & 5 & 0 \\
\hline Lye Branch, site 6 & 4 & 1.09 & 0 & 3 & 1 & 7 & 1.27 & 3 & 2 & 2 & 7 & 1.30 & 0 & 3 & 4 \\
\hline All sites & 17 & 1.01 & 5 & 8 & 4 & 24 & 1.15 & 9 & 6 & 9 & 42 & 1.07 & 16 & 16 & 10 \\
\hline \multicolumn{6}{|c|}{ All sites-All phases of construction } & 83 & 1.08 & 30 & 29 & 24 & & & & & \\
\hline \multicolumn{16}{|c|}{ Ratio of upstream to downstream turbidity } \\
\hline High Log Creek, site 1 & 5 & 1.21 & 2 & 2 & 1 & 5 & 0.61 & 1 & 3 & 1 & 7 & 0.99 & 1 & 5 & 1 \\
\hline $\begin{array}{l}\text { Tributary to Cahaba River, } \\
\text { site } 2\end{array}$ & -- & -- & -- & -- & -- & 4 & 0.32 & 4 & 0 & 0 & 7 & 0.97 & 2 & 4 & 1 \\
\hline $\begin{array}{l}\text { Tributary to Sandy Creek, } \\
\text { site } 3\end{array}$ & -- & -- & -- & -- & -- & 3 & 0.80 & 2 & 0 & 1 & 9 & 1.37 & 1 & 2 & 6 \\
\hline Oakmulgee Creek, site 4 & 5 & 1.37 & 1 & 3 & 1 & 5 & 1.20 & 1 & 1 & 3 & 4 & 1.10 & 0 & 3 & 1 \\
\hline Northington Branch, site 5 & 2 & 0.84 & 2 & 0 & 0 & -- & -- & -- & -- & -- & 11 & 1.33 & 4 & 4 & 3 \\
\hline Lye Branch, site 6 & 4 & 1.13 & 0 & 2 & 2 & 6 & 0.86 & 4 & 2 & 0 & 7 & 1.02 & 0 & 6 & 1 \\
\hline All sites & 16 & 1.08 & 5 & 7 & 4 & 23 & 0.88 & 12 & 6 & 5 & 45 & 1.16 & 8 & 24 & 13 \\
\hline \multicolumn{6}{|c|}{ All sites-All phases of construction } & 84 & 1.07 & 25 & 37 & 22 & & & & & \\
\hline
\end{tabular}


Table 13. Storm events and maximum measured streamflow at selected study sites in Alabama.

[BC, before construction; DC, during construction; AC, after construction; hr:min, hours:minutes; ft, foot; Max streamflow, maximum measured streamflow; $\mathrm{ft}^{3} / \mathrm{s}$, cubic feet per second; dates are in month/day/year format; time is in hour:minute format]

\begin{tabular}{|c|c|c|c|c|c|}
\hline $\begin{array}{c}\text { Construction } \\
\text { phase }\end{array}$ & $\begin{array}{l}\text { Date (and time) of } \\
\text { start of storm event }\end{array}$ & $\begin{array}{l}\text { Date (and time) of } \\
\text { end of storm event }\end{array}$ & $\begin{array}{l}\text { Elapsed time } \\
\text { (hr:min) }\end{array}$ & $\begin{array}{l}\text { Difference between } \\
\text { maximum and } \\
\text { minimum stage } \\
\text { (ft) }\end{array}$ & $\begin{array}{c}\text { Max } \\
\text { streamflow } \\
\left(\mathrm{ft}^{3} / \mathbf{s}\right)\end{array}$ \\
\hline \multicolumn{6}{|c|}{ High Log Creek, site 1} \\
\hline $\mathrm{BC}$ & 7/15/11 (23:15) & 7/16/11 (2:30) & $3: 15$ & 1.48 & 153 \\
\hline $\mathrm{BC}$ & 2/25/13 (11:10) & $2 / 25 / 13(15: 25)$ & $4: 15$ & 0.64 & 104 \\
\hline $\mathrm{DC}$ & $5 / 26 / 15(16: 55)$ & $5 / 26 / 15(20: 48)$ & $3: 53$ & 2.4 & 182 \\
\hline $\mathrm{AC}$ & 2/7/18 (14:00) & 2/7/18 (16:25) & $2: 25$ & 0.22 & 37.4 \\
\hline $\mathrm{AC}$ & $3 / 6 / 18(14: 30)$ & $3 / 6 / 18(16: 45)$ & $2: 15$ & 0.28 & 49 \\
\hline $\mathrm{AC}$ & 10/10/18 (18:40) & $10 / 10 / 18(23: 35)$ & $4: 55$ & 1.01 & 167 \\
\hline $\mathrm{DC}$ & 4/4/11 (19:25) & 4/5/11 (0:50) & $5: 25$ & 0.25 & 2.95 \\
\hline $\mathrm{AC}$ & 12/8/18 (16:05) & $12 / 8 / 18(20: 20)$ & $4: 15$ & 0.24 & 7.86 \\
\hline \multirow[t]{3}{*}{$\mathrm{AC}$} & 4/18/19 (22:04) & 4/19/19 (1:40) & $3: 36$ & 0.53 & 12 \\
\hline & & Mean: & $4: 25$ & 0.34 & 7.6 \\
\hline & & Median: & $4: 15$ & 0.25 & 7.86 \\
\hline \multicolumn{6}{|c|}{ Tributary to Sandy Creek, site 3} \\
\hline $\mathrm{DC}$ & $1 / 30 / 13(9: 15)$ & $1 / 30 / 13(11: 15)$ & $2: 00$ & 0.66 & 16.4 \\
\hline $\mathrm{AC}$ & $12 / 8 / 18(15: 19)$ & $12 / 8 / 18(21: 49)$ & $6: 30$ & 0.91 & 10.1 \\
\hline $\mathrm{AC}$ & 4/18/19 (21:21) & 4/19/19 (1:50) & $4: 29$ & 0.28 & 7 \\
\hline $\mathrm{DC}$ & 9/15/14 (19:08) & 9/15/14 (20:40) & $1: 32$ & 0.16 & 36.6 \\
\hline DC & $10 / 13 / 14(23: 35)$ & $10 / 14 / 14(0: 26)$ & $0: 51$ & 2.34 & -- \\
\hline $\mathrm{AC}$ & $3 / 8 / 17(0: 38)$ & 3/8/17 (1:52) & $1: 14$ & 0.45 & 130 \\
\hline $\mathrm{AC}$ & 4/3/17 (10:10) & 4/3/17 (11:55) & $1: 45$ & 1.9 & 193 \\
\hline \multirow[t]{3}{*}{$\mathrm{AC}$} & 4/27/17 (11:05) & $4 / 27 / 17(11: 45)$ & $0: 40$ & 0.01 & 15.8 \\
\hline & & Mean: & $2: 04$ & 0.68 & 103 \\
\hline & & Median: & $1: 38$ & 0.27 & 128 \\
\hline \multicolumn{6}{|c|}{ Northington Branch, site 5} \\
\hline $\mathrm{BC}$ & 9/5/11 (7:50) & 9/5/11 (14:00) & $6: 10$ & 0.62 & 29.9 \\
\hline $\mathrm{AC}$ & $4 / 10 / 15(7: 20)$ & 4/10/15 (11:40) & $4: 20$ & 0.29 & 27.9 \\
\hline $\mathrm{AC}$ & 11/18/15 (8:00) & 11/18/15 (11:34) & $3: 34$ & 0.92 & 49.9 \\
\hline \multirow[t]{3}{*}{$\mathrm{AC}$} & 2/23/16 (22:05) & $2 / 24 / 16(1: 20)$ & $3: 15$ & 1.12 & 42.7 \\
\hline & & Mean: & $4: 19$ & 0.74 & 37.6 \\
\hline & & Median: & $3: 57$ & 0.77 & 36.3 \\
\hline
\end{tabular}


Table 13. Storm events and maximum measured streamflow at selected study sites in Alabama.—Continued

[BC, before construction; DC, during construction; AC, after construction; hr:min, hours:minutes; ft, foot; Max streamflow, maximum measured streamflow; $\mathrm{ft}^{3} / \mathrm{s}$, cubic feet per second; dates are in month/day/year format; time is in hour:minute format]

\begin{tabular}{|c|c|c|c|c|c|}
\hline $\begin{array}{c}\text { Construction } \\
\text { phase }\end{array}$ & $\begin{array}{l}\text { Date (and time) of } \\
\text { start of storm event }\end{array}$ & $\begin{array}{l}\text { Date (and time) of } \\
\text { end of storm event }\end{array}$ & $\begin{array}{c}\text { Elapsed time } \\
\text { (hr:min) }\end{array}$ & $\begin{array}{l}\text { Difference between } \\
\text { maximum and } \\
\text { minimum stage } \\
\text { (ft) }\end{array}$ & $\begin{array}{c}\text { Max } \\
\text { streamflow } \\
\left(\mathrm{ft}^{3} / \mathrm{s}\right)\end{array}$ \\
\hline \multicolumn{6}{|c|}{ Lye Branch, site 6} \\
\hline $\mathrm{BC}$ & 4/15/11 (20:25) & 4/16/11 (1:05) & $4: 40$ & 0.77 & 130 \\
\hline $\mathrm{BC}$ & $12 / 20 / 12(10: 55)$ & $12 / 20 / 12(12: 25)$ & $1: 30$ & 0.15 & -- \\
\hline $\mathrm{DC}$ & $2 / 21 / 14(17: 22)$ & $2 / 21 / 14(19: 11)$ & $1: 49$ & 0.91 & 179 \\
\hline $\mathrm{DC}$ & 4/6/14 (22:07) & 4/7/14 (1:08) & $3: 01$ & 1.45 & -- \\
\hline $\mathrm{AC}$ & 3/7/17 (18:30) & $3 / 7 / 17(23: 08)$ & $4: 38$ & 1.46 & 117 \\
\hline $\mathrm{AC}$ & $6 / 21 / 17(18: 45)$ & $6 / 21 / 17(21: 20)$ & $2: 35$ & 0.2 & 48.2 \\
\hline
\end{tabular}

\section{Benthic Macroinvertebrate Sampling}

Benthic macroinvertebrates were collected from instream habitats upstream and downstream of the culvert construction reaches to assess the ecological effects of culvert construction. The benthic macroinvertebrate communities were considered suitable indicators of subtle changes to stream channel, flow, and water quality that may have been caused by culvert construction because different benthic macroinvertebrate organisms prefer specialized habitats in terms of flow, depth, organic material, water chemistry, and other stream characteristics (Voshell, 2002).

Benthic macroinvertebrate sample collection was planned once for the before-construction period and once for the afterconstruction period at all sites except the Tributary to Sandy Creek site, which was excluded because of frequent zero-flow conditions. In the summer of 2011, benthic macroinvertebrate communities were sampled to represent before-construction conditions at all sites except High Log Creek (site 1), which was not sampled in 2011 because of zero-flow conditions during the sampling period. At the Tributary to Cahaba River (site 2) in 2011, the culvert was already constructed, and road-building activities were ongoing. For this reason, the sample collected in 2011 from the Tributary to Cahaba River site is considered representative only of during-construction conditions. To represent after-construction conditions, samples were collected for analysis of benthic macroinvertebrate communities during 2014-18, depending on the schedule of culvert construction, with most samples collected during 2017 (table 14). During this study, discrete samples were collected from upstream and downstream reaches at each of the streams. Biological data for all sites are available in Gill and Pugh (2021).
Samples were collected from one or more of the richesttargeted habitats that were in common between the upstream and downstream reaches. Richest-targeted habitats are instream habitats that are considered most likely to support a diverse and abundant community of macroinvertebrates. Available habitat types varied from site to site and from time period to time period. Woody debris, riffles, roots, and undercut banks were the most commonly sampled habitats (table 14). Sample collection methods generally followed protocols established by the USGS National Water-Quality Assessment (NAWQA) Program (Moulton and others, 2002) and varied based on the type of sampled habitats. Woody snags were collected into D-frame or rectangular nets, riffle areas were sampled by using the Slack sampler, and root and undercut bank samples were collected by jabbing undercut banks with D-frame nets. Field processing for samples from all habitat types followed the NAWQA protocols (Moulton and others, 2002).

Field parameters used for measuring water quality were recorded at some sampling sites (table 14), and habitat scores were assigned for sites sampled in 2017 and 2018. Habitat assessments were made during after-construction sampling by using the U.S. Environmental Protection Agency's (EPA) Rapid Bioassessment Protocol II (Barbour and others, 1999). Habitat parameters and the ranges of scores associated with stream condition categories are summarized in table 15 . Habitat scores assigned to the study streams (table 16) were used to analyze differences between upstream and downstream benthic macroinvertebrate communities.

Identification and enumeration of macroinvertebrates were determined by the USGS National Water Quality Laboratory (NWQL) Biological Group. Samples were sorted and processed using methods similar to those in the Alabama 
Table 14. Sampled instream habitats and after-construction water-quality field parameters at selected new culvert installation sites, Alabama.

[temp., temperature; ${ }^{\circ} \mathrm{C}$, degrees Celsius; DO, dissolved oxygen; mg/L, milligrams per liter; $\mathrm{SC}$, specific conductance; $\mu \mathrm{S} / \mathrm{cm}, \mathrm{microsiemens}$ per centimeter; AC, after construction; US, upstream; DS, downstream; DC, during construction; BC, before construction; $\mathrm{m}^{2}$, square meter; dates are in month/day/year format; --, no data]

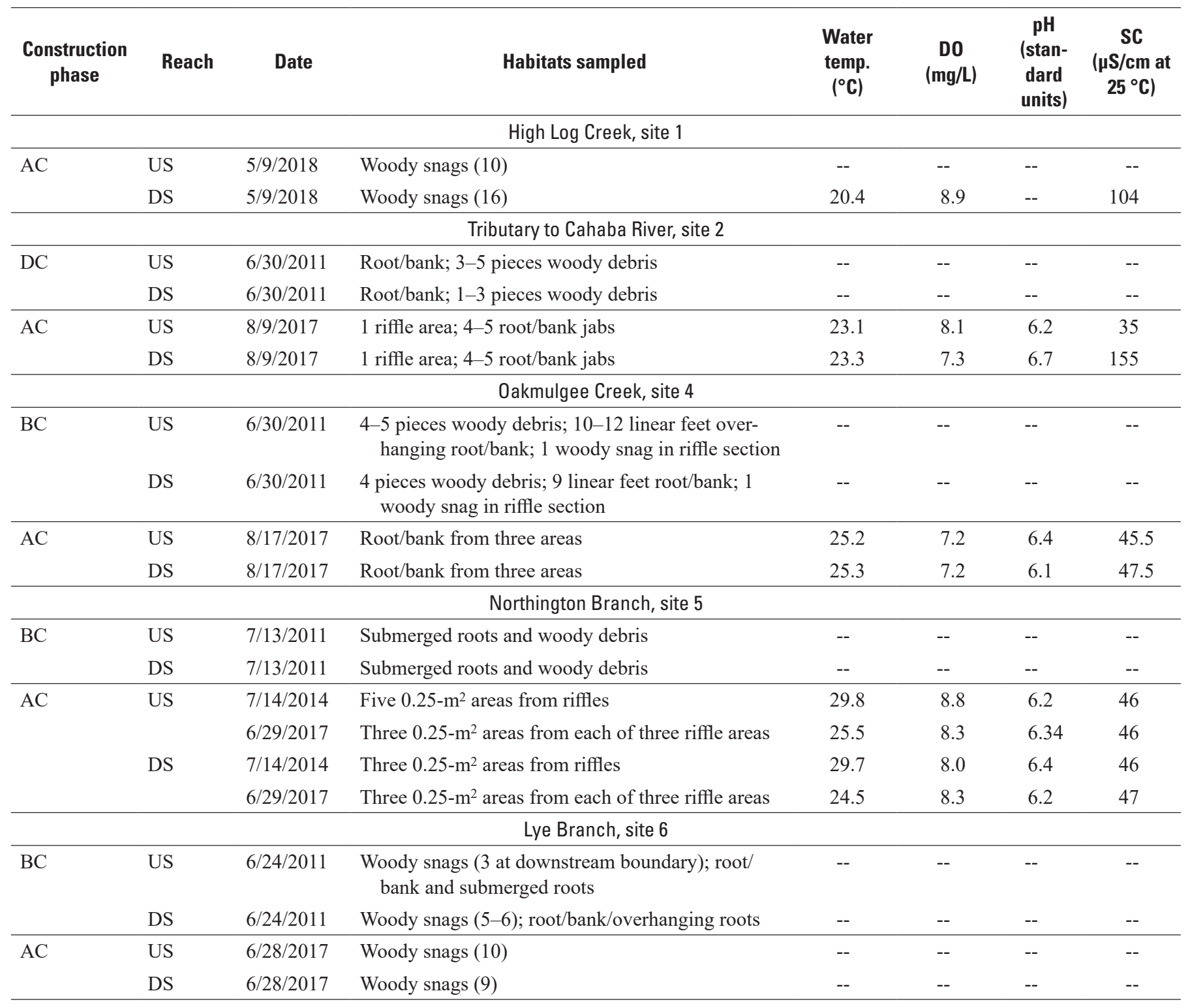

Department of Environmental Management (ADEM) Standard Operating Procedures \#6001 for sorting greater than or equal to 100 organisms (Alabama Department of Environmental Management, 2008). Sorted macroinvertebrates were identified using ADEM Standard Operating Procedures \#6002 (Alabama Department of Environmental Management, 2007). The macroinvertebrate data are available in Gill and Pugh (2021) and were entered into the USGS Invertebrate Data Analysis System (IDAS) software (Cuffney and Brightbill, 2010).

USGS IDAS was used to calculate multiple community metrics from taxonomic data produced from the macroinvertebrate samples. The metric groups important to this study were measures of abundance, taxa richness, and average community tolerance to pollution. Metrics were based on genera or the lowest level of identification above genus. Metrics at all sites were examined before and after construction. Metrics were expected to be similar between upstream and downstream reaches before culvert construction. If the construction or presence of culverts caused changes in geomorphology, substrate, microflow patterns, vegetation, or other stream characteristics, these changes could affect the species composition of the benthic macroinvertebrate communities, which could potentially be reflected in changes in the community metric values. 
Table 15. Habitat parameters and scores for condition category (Barbour and others, 1999).

\begin{tabular}{lcccc}
\hline \multirow{2}{*}{$\quad$ Habitat parameters } & \multicolumn{3}{c}{ Scores for condition category } \\
\cline { 2 - 5 } & Optimal & Suboptimal & Marginal & Poor \\
\hline Epifaunal substrate/available cover & $20-16$ & $15-11$ & $10-6$ & $5-0$ \\
Pool substrate characterization & $20-16$ & $15-11$ & $10-6$ & $5-0$ \\
Pool variability & $20-16$ & $15-11$ & $10-6$ & $5-0$ \\
Sediment deposition & $20-16$ & $15-11$ & $10-6$ & $5-0$ \\
Channel flow status & $20-16$ & $15-11$ & $10-6$ & $5-0$ \\
Channel alteration & $20-16$ & $15-11$ & $10-6$ & $5-0$ \\
Channel sinuosity & $20-16$ & $15-11$ & $10-6$ & $5-0$ \\
Bank stability & $10-9$ & $8-6$ & $5-3$ & $2-0$ \\
Vegetative protection & $10-9$ & $8-6$ & $5-3$ & $2-0$ \\
Riparian vegetative zone & $10-9$ & $8-6$ & $5-3$ & $2-0$ \\
\hline Range of score totals for condition category & $200-166$ & $153-113$ & $100-60$ & $47-0$ \\
\hline
\end{tabular}

Several methods have been developed to assign tolerance values (TVs) to benthic macroinvertebrate taxa based on their sensitivity to the presence and severity of pollutants or disturbances in the sampled waterbody (Barbour and others, 1999; Chang and others, 2014). For this study, TVs included with the IDAS software were used to examine average community tolerance. The IDAS software includes regional TVs developed by the EPA for the Rapid Bioassessment Protocol (Barbour and others, 1999; Cuffney and Brightbill, 2010) for individual taxa, though some regions do not have assigned TVs for all taxa. The IDAS uses the mean of all regional TVs for a taxon as a national TV for that taxon, and these existing national TVs were used in analyses for this study. For evaluation of differences in average community tolerance among sites, the following TV ranges were used: 0 to 4 for intolerant communities, 4 to 7 for moderately tolerant communities, and 7 or greater for tolerant communities.

Average community TVs were determined within IDAS based on the abundance of individuals within each taxon, or taxa richness. Abundance-weighted average TVs were calculated by using equation 1 :

$$
\sum_{i=1}^{N} T V_{i} A_{i} / N
$$

where

$$
\begin{aligned}
T V_{i} & \text { is the tolerance value of taxon " } i, \\
A_{i} & \text { is the abundance of taxon " } i, \text {, and } \\
N & \text { is the total number of benthic } \\
& \text { macroinvertebrates in the sample. }
\end{aligned}
$$

Richness-based average TVs were calculated by using equation 2:

$$
\sum_{i=1}^{n} T V_{i} / n
$$

where

$$
\begin{gathered}
T V_{i} \quad \text { is the tolerance value of taxon " } i, \text {, and } \\
n \quad \text { is the number of taxa in the sample (Cuffney } \\
\text { and Brightbill, 2010). }
\end{gathered}
$$

The Wilcoxon rank sum nonparametric statistical test was used to evaluate differences between upstream and downstream metrics before and after culvert construction. For example, for each construction period, taxa richness in the sample from the downstream reach was subtracted from taxa richness in the sample from the upstream reach for each site. The result was designated as the site's upstream to downstream difference in taxa richness for that construction period. If culvert construction had altered stream conditions enough to affect taxa richness, then the after-construction upstream to downstream difference would vary from the beforeconstruction upstream to downstream difference. Beforeconstruction upstream to downstream differences for all sites were pooled and compared to pooled after-construction differences by using an exact Wilcoxon rank sum test. Not all sites were sampled both before and after culvert construction. The group of before-construction samples contained three sample differences, and the group of after-construction samples included six sample differences. The sample collected in 2011 from the Tributary to Cahaba River (site 2) was not included in this analysis because it represented during-construction conditions.

To further examine the relations between upstream and downstream conditions, Bland-Altman plots were created for upstream to downstream differences for each of the metrics examined in this report. The Bland-Altman plot is an $\mathrm{x}-\mathrm{y}$ scatter of the difference between pairs of data plotted against the means of the pairs. The mean difference between the pairs and the upper and lower limits of agreement (values at plus and minus two standard deviations of the mean) are graphed as horizontal lines to help identify any outliers in the differences (Bland and Altman, 1986, 1999; Glen, 2016). 
Table 16. Habitat scores for each reach at selected sites sampled for benthic macroinvertebrate communities, Alabama.

[USGS, U.S. Geological Survey; US, upstream; DS, downstream; dates are in month/day/year format; see table 14 for more information about habitat scores; protocols for assigning scores from Barbour and others (1999)]

\begin{tabular}{|c|c|c|c|c|c|c|c|c|c|c|c|}
\hline \multicolumn{2}{|c|}{ Sample date } & \multicolumn{2}{|c|}{$5 / 9 / 2018$} & \multicolumn{2}{|c|}{$8 / 9 / 2017$} & \multicolumn{2}{|c|}{ 8/17/2017 } & \multicolumn{2}{|c|}{$6 / 29 / 2017$} & \multicolumn{2}{|c|}{$6 / 28 / 2017$} \\
\hline \multicolumn{2}{|c|}{ Site number } & \multicolumn{2}{|c|}{1} & \multicolumn{2}{|c|}{2} & \multicolumn{2}{|c|}{4} & \multicolumn{2}{|c|}{5} & \multicolumn{2}{|c|}{6} \\
\hline \multicolumn{2}{|c|}{ Abbreviated site name } & \multicolumn{2}{|c|}{ High Log Creek } & \multicolumn{2}{|c|}{ Tributary to Cahaba River } & \multicolumn{2}{|c|}{ Oakmulgee Creek } & \multicolumn{2}{|c|}{ Northington Branch } & \multicolumn{2}{|c|}{ Lye Branch } \\
\hline \multicolumn{2}{|c|}{ USGS station number ${ }^{1}$} & 02342870 & 02342871 & 02423990 & 02423991 & 02424750 & 02424751 & 02439159 & 02439160 & 02465390 & 02465391 \\
\hline \multicolumn{2}{|c|}{ Sample reach } & US & DS & US & DS & US & DS & US & DS & US & DS \\
\hline \multicolumn{12}{|c|}{ Habitat parameters } \\
\hline \multicolumn{2}{|c|}{$\begin{array}{l}\text { Epifaunal substrate/available } \\
\text { cover }\end{array}$} & 6 & 5 & 16 & 18 & 15 & 15 & 15 & 13 & 13 & 15 \\
\hline \multicolumn{2}{|c|}{ Pool substrate characterization } & 3 & 8 & 18 & 19 & 11 & 11 & 18 & 18 & 9 & 8 \\
\hline \multicolumn{2}{|c|}{ Pool variability } & 213 & 10 & 15 & 19 & 16 & 14 & 3 & 8 & 14 & 13 \\
\hline \multicolumn{2}{|c|}{ Sediment deposition } & 7 & 5 & 11 & 13 & 8 & 8 & 10 & 13 & 8 & 11 \\
\hline \multicolumn{2}{|c|}{ Channel flow status } & 20 & 20 & 12 & 16 & 8 & 8 & 8 & 13 & 16 & 20 \\
\hline \multicolumn{2}{|c|}{ Channel alteration } & 13 & 15 & 18 & 14 & 19 & 13 & 8 & 14 & 13 & 12 \\
\hline \multicolumn{2}{|c|}{ Channel sinuosity } & 9 & 8 & 14 & 19 & 13 & 13 & 5 & 5 & 5 & 5 \\
\hline \multirow{2}{*}{$\begin{array}{l}\text { Bank stabil- } \\
\text { ity }\end{array}$} & Left bank & 9 & 7 & 6 & 8 & 7 & 8 & 8 & 7 & 7 & 6 \\
\hline & Right bank & 8 & 7 & 8 & 8 & 7 & 8 & 8 & 7 & 7 & 6 \\
\hline \multirow{2}{*}{$\begin{array}{l}\text { Vegetative } \\
\text { protection }\end{array}$} & Left bank & 8 & 7 & 8 & 8 & 10 & 9 & 8 & 7 & 8 & 4 \\
\hline & Right bank & 5 & 7 & 9 & 10 & 10 & 9 & 10 & 7 & 8 & 4 \\
\hline \multirow{2}{*}{$\begin{array}{l}\text { Riparian } \\
\text { vegetative } \\
\text { zone }\end{array}$} & Left bank & 9 & 5 & 8 & 4 & 9 & 4 & 0 & 1 & 10 & 10 \\
\hline & Right bank & 3 & 5 & 6 & 8 & 10 & 8 & 2 & 1 & 10 & 5 \\
\hline \multicolumn{2}{|l|}{ Total score } & 100 & 109 & 149 & 164 & 143 & 128 & 103 & 114 & 128 & 119 \\
\hline
\end{tabular}

${ }^{1}$ USGS National Water Information System database (U.S. Geological Survey, 2020).

${ }^{2}$ Pool variability score affected by beaver activity that increased pools in the reach. 
For Bland-Altman plots in this report, mean differences and limits of agreement were calculated without the sample collected in 2011 from the Tributary to Cahaba River site, but the scatter points for that data are plotted for comparison of during-construction data to before- and after-construction data.

\section{Physical Parameters Analysis}

Physical data, including channel geometry parameters, suspended sediment and turbidity, were analyzed for each of the six study reaches. The following sections of this report include a brief summary of the study reach and analysis of changes between the before- and after-construction channel geometry parameters (cross-sectional area, width, mean depth, and thalweg profile) and the before-, during-, and afterconstruction changes in suspended sediment and turbidity.

The suggested cause for the observed changes at each site could be one of many conceivable scenarios based on two or three observations. Because consideration of all possible scenarios would be cumbersome, only causes that are associated with culvert construction are presented here. Additional observations may help to refine the causes for the observed changes and to further the understanding of the effects these new culverts are having on streams.

\section{High Log Creek Near Hatchechubbee - Site 1}

The High Log Creek site is in Russell County, central Alabama, approximately 1.4 miles west of Hatchechubbee on State Highway 26 (figs. 1 and 5). The stream is part of the Apalachicola subregional hydrologic unit (fig. 3; table 5). The drainage area above the study site is $13.7 \mathrm{mi}^{2}$ (table 1); in 2011, 66.0 percent of the drainage area was forest, and 24.5 percent was grassland/shrub (tables 7 and 8 ). The estimated 2-year peak streamflow is $956 \mathrm{ft}^{3} / \mathrm{s}$ (table 6). Between August 2013 and September 2016, a triple barrel, cast-inplace, concrete box culvert was constructed at the site to replace an existing bridge (table 2 ).

In addition to the culvert construction, other anthropogenic activities occurred near the High Log Creek site. Comparison of the February 26, 2015, imagery from Google Earth, with imagery from February 16, 2013, indicates a large area of forest was cleared upstream of the culvert at the High Log Creek site. Google Earth images of the study reaches are available from Gill and Pugh (2021).

\section{Stream Channel Geometry}

At the High Log Creek site, the only statistically significant changes in the channel geometry parameters were for the upstream cross-sectional area $\left(-12.85 \mathrm{ft}^{2}\right)$ and mean depth $(-0.52 \mathrm{ft})$ (table 10). It should be noted that the afterconstruction, upstream thalweg reach slope was inverted (positive slope; table 9) and the two after-construction, upstream thalweg elevation measurements nearest the culvert were approximately $3 \mathrm{ft}$ above the corresponding beforeconstruction measurements (fig. 4A). A cofferdam made of steel sheet piling reinforced with stacked rip rap was built just upstream of the culvert during construction. Remnants of the cofferdam remained through the after-construction observations. The presence of the cofferdam and its remnants caused sediment deposition in the upstream reach, resulting in the observed inverted channel slope and reduced mean depth and cross-sectional area.

\section{Streamflow, Sediment, and Turbidity}

At the High Log Creek site, surface-water samples were collected during each of the construction phases at similar streamflows with the two lowest streamflows measured during the after-construction phase (table 13). The beforeconstruction, upstream to downstream mean paired sample ratios indicate that suspended sediment concentrations were nearly equal (0.97), but turbidity was greater upstream (1.21) (table 12). This suggests that the construction reach was trapping colloidal sediment (silt, clay, and organic matter). The during-construction mean paired sample ratios indicate that suspended sediment concentrations were nearly equal (1.02), but turbidity was greater downstream (0.61) (table 12). This suggests that the colloidal sediment (silt, clay, and organic material) was mobilized as the stream passed through the construction reach. The after-construction mean paired sample ratios indicate that suspended sediment concentrations and turbidity were both nearly equal ( 0.96 and 0.99 , respectively) (table 12), suggesting that the creek's sediment load was efficiently passing through the construction reach.

\section{Tributary to Cahaba River Near Centreville - Site 2}

The Tributary to Cahaba River site is in Bibb County, central Alabama, approximately 1.1 miles northeast of Centreville on U.S. Highway 82 (figs. 1 and 6). The tributary is part of the Alabama subregional hydrologic unit (fig. 3; table 5). The drainage area above the study site is $0.39 \mathrm{mi}^{2}$ (table 1); in 2011, 79.7 percent of the drainage area was forest, and 10.9 percent was grassland/shrub (tables 7 and 8). The estimated 2-year peak streamflow is $94.0 \mathrm{ft}^{3} / \mathrm{s}$ (table 6). Between November 2010 and August 2013, a single barrel precast concrete box culvert was constructed by using a buried culvert inverts design as part of the new U.S. Highway 82 corridor construction (table 2 ).

\section{Stream Channel Geometry}

At the Tributary to Cahaba River study site, statistically significant changes in the channel geometry parameters occurred in the upstream and downstream cross-sectional areas (3.15 $\mathrm{ft}^{2}$ and $1.30 \mathrm{ft}^{2}$, respectively) and mean depths 


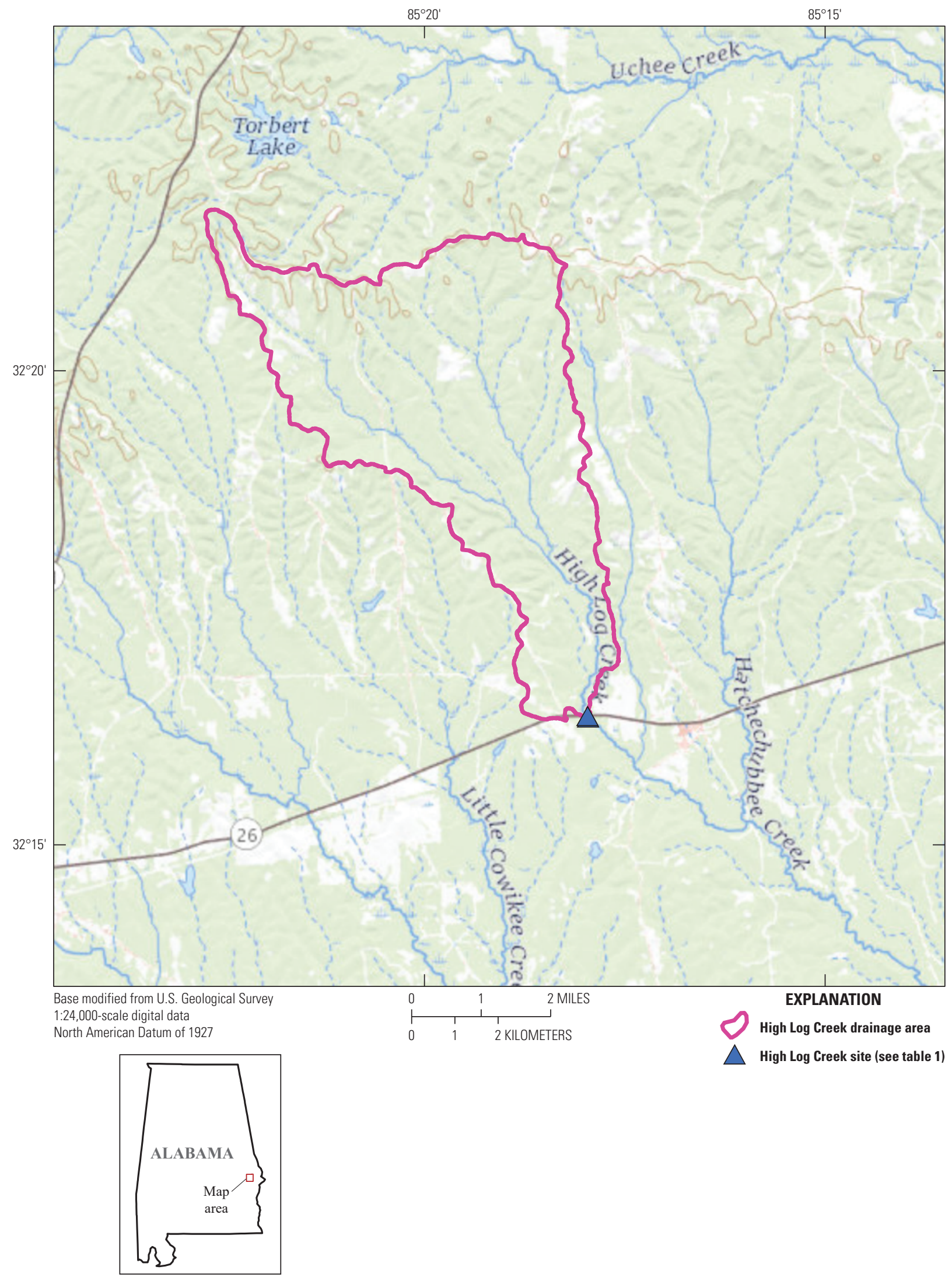

Figure 5. Location of High Log Creek near Hatchechubbee (site 1) and the associated drainage area. 


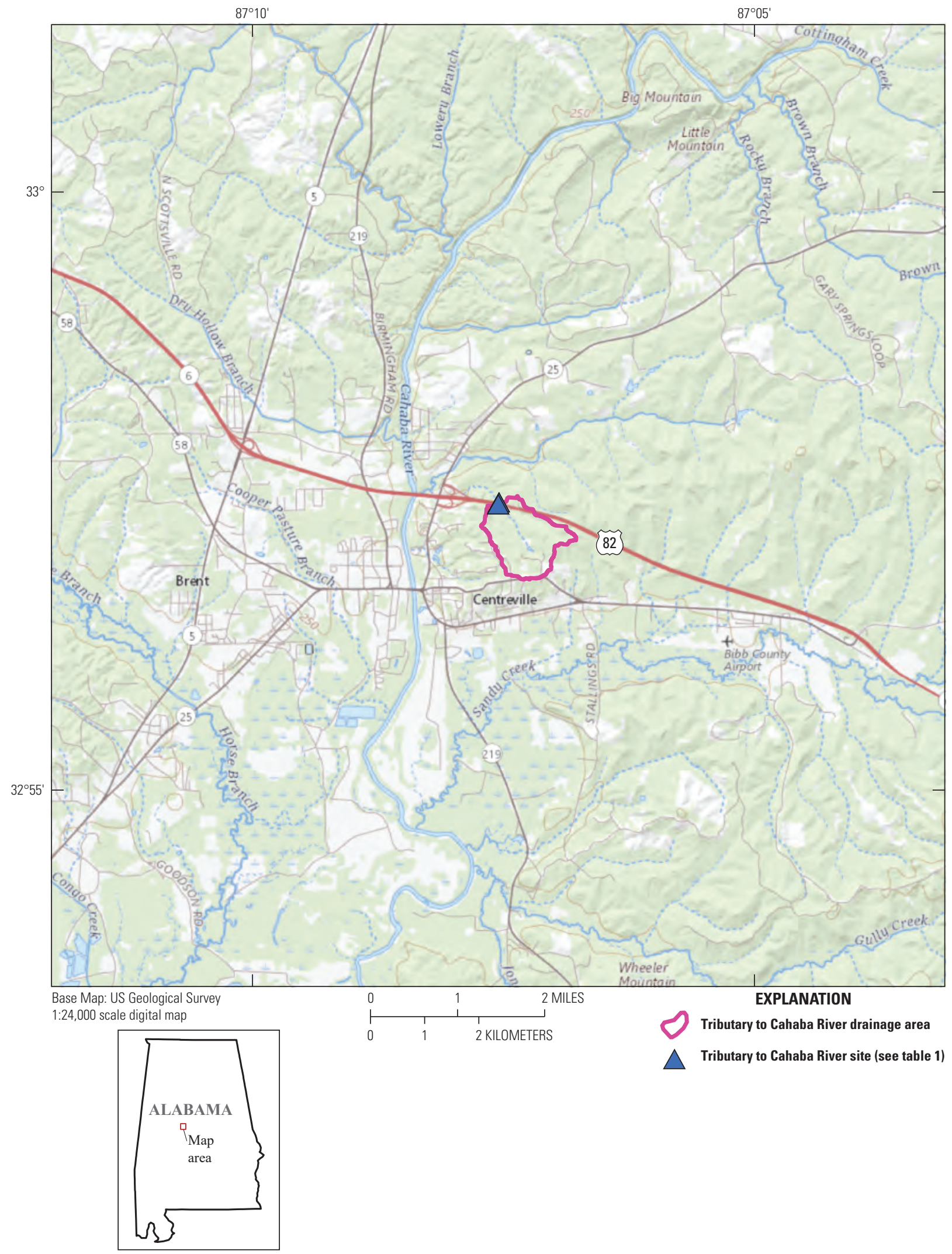

Figure 6. Location of Tributary to Cahaba River near Centreville (site 2) and the associated drainage area. 
$(0.21 \mathrm{ft}$ and $0.09 \mathrm{ft}$, respectively) (table 9). Although the thalweg slopes did not change significantly, the upstream and downstream thalweg elevations were lower in the afterconstruction phase (table 10; figs. $4 C$ and $4 D$ ). This suggests that the culvert inverts were set at an elevation below the before-construction thalweg, thus inducing erosion in the upstream reach and increasing the cross-sectional areas and mean depths observed in the upstream reach. Erosion of the downstream reach indicates that the construction site's erosion control measures trapped sediment, resulting in sedimentfree water exiting the site and eroding the upstream part of the downstream reach; the observed increases in the crosssectional areas and mean depths in the downstream reach also support this conclusion.

\section{Streamflow, Sediment, and Turbidity}

At the Tributary to Cahaba River study site, samples were collected during three storm events; one was during construction, and two were after construction (tables 11 and 13). The during-construction, upstream to downstream mean paired sample ratios indicate suspended sediment concentrations and turbidity were greater downstream $(0.30$ and 0.32 , respectively) (table 12), suggesting that sediment was mobilized as the stream passed through the construction reach. The afterconstruction mean paired sample ratios indicate that sediment concentrations were greater upstream (1.83), but turbidity was nearly equal (0.97) upstream and downstream (table 12). This suggests that the construction reach was trapping the larger sediment particles (sand), while the colloidal part of the suspended sediment (silt, clay, and organic material) passed through the construction reach. Together, the after-construction channel geometry and sediment data suggest that the thalweg of the stream was still adjusting to match the upstream and downstream channel reaches.

\section{Tributary to Sandy Creek Near Vick - Site 3}

The Tributary to Sandy Creek site is in Bibb County, central Alabama, approximately 0.5 mile east of Vick on U.S. Highway 82 (figs. 1 and 7). The tributary is part of the Alabama subregional hydrologic unit (fig. 3; table 5). The drainage area above the study site is $1.34 \mathrm{mi}^{2}$ (table 1). In 2011, 83.8 percent of the drainage area was forest, and 10.5 percent was grassland/shrub (tables 7 and 8). The estimated 2-year peak streamflow is $235 \mathrm{ft}^{3} / \mathrm{s}$ (table 6). Between November 2010 and August 2013, a triple barrel cast-in-place, concrete box culvert was constructed as part of the new U.S. Highway 82 corridor construction (table 2).

\section{Stream Channel Geometry}

At the Tributary to Sandy Creek study site, no statistically significant changes in the channel geometry parameters occurred (tables 9 and 10). Note that the after-construction, downstream thalweg slope was inverted (table 10), and the after-construction, downstream thalweg elevations nearest the culvert were lower than the before construction elevations by approximately 0.3 foot (ft) (fig. $4 F$ ). In addition to the culvert, several other engineered structures were built within the construction reach. These structures included a temporary bypass channel to convey streamflow around the construction area, ditches on both sides of the new highway that drain into the creek, and an engineered energy dissipation basin at the outlet of the culvert. Together, the observed inverted downstream thalweg slope and lower downstream thalweg elevations suggest that sediment-free water exited the construction reach, eroding the streambed in the upper parts of the downstream reach.

\section{Streamflow, Sediment, and Turbidity}

At the Tributary to Sandy Creek site, no samples were collected during storm events before construction began, samples were collected during one storm event during construction, and samples were collected during two storm events after construction (table 13). The storm event with the maximum measured streamflow occurred in the during-construction phase (table 13). The during-construction, upstream to downstream mean paired sample ratios indicate sediment concentrations were greater upstream (1.19), but turbidity was greater downstream (0.80) (table 12$)$. This suggests that the relatively larger particles of the suspended sediment load (sand) were being trapped within the construction reach while the relatively smaller colloidal sediment (silt, clay, and organic material) was being mobilized from the construction reach during construction. The after-construction mean paired sample ratios indicate that sediment concentrations were greater downstream $(0.65)$ while turbidity was greater upstream (1.37) (table 12). This suggests that the relatively larger particles of suspended sediment (sand) were being mobilized within the construction reach while the relatively smaller colloidal particles (silt, clay, and organic material) were being trapped within the construction reach after construction.

Together, the channel geometry and sediment data suggest that after construction, the release of sediment-free water did not continue. Energy dissipation in the basin and the construction site's erosion control measures combined to prevent sediment from exiting the site during construction. Once the culvert construction was completed and the erosion control measures removed, the suspended sediment load returned to normal.

\section{Oakmulgee Creek Near Lawley - Site 4}

The Oakmulgee Creek site is in Bibb County, central Alabama, approximately 1.2 miles southwest of Lawley on U.S. Highway 82 (figs. 1 and 8). Oakmulgee Creek is part of the Alabama subregional hydrologic unit (fig. 3; table 5). The drainage area above the study site is $12.5 \mathrm{mi}^{2}$ (table 1 ). 


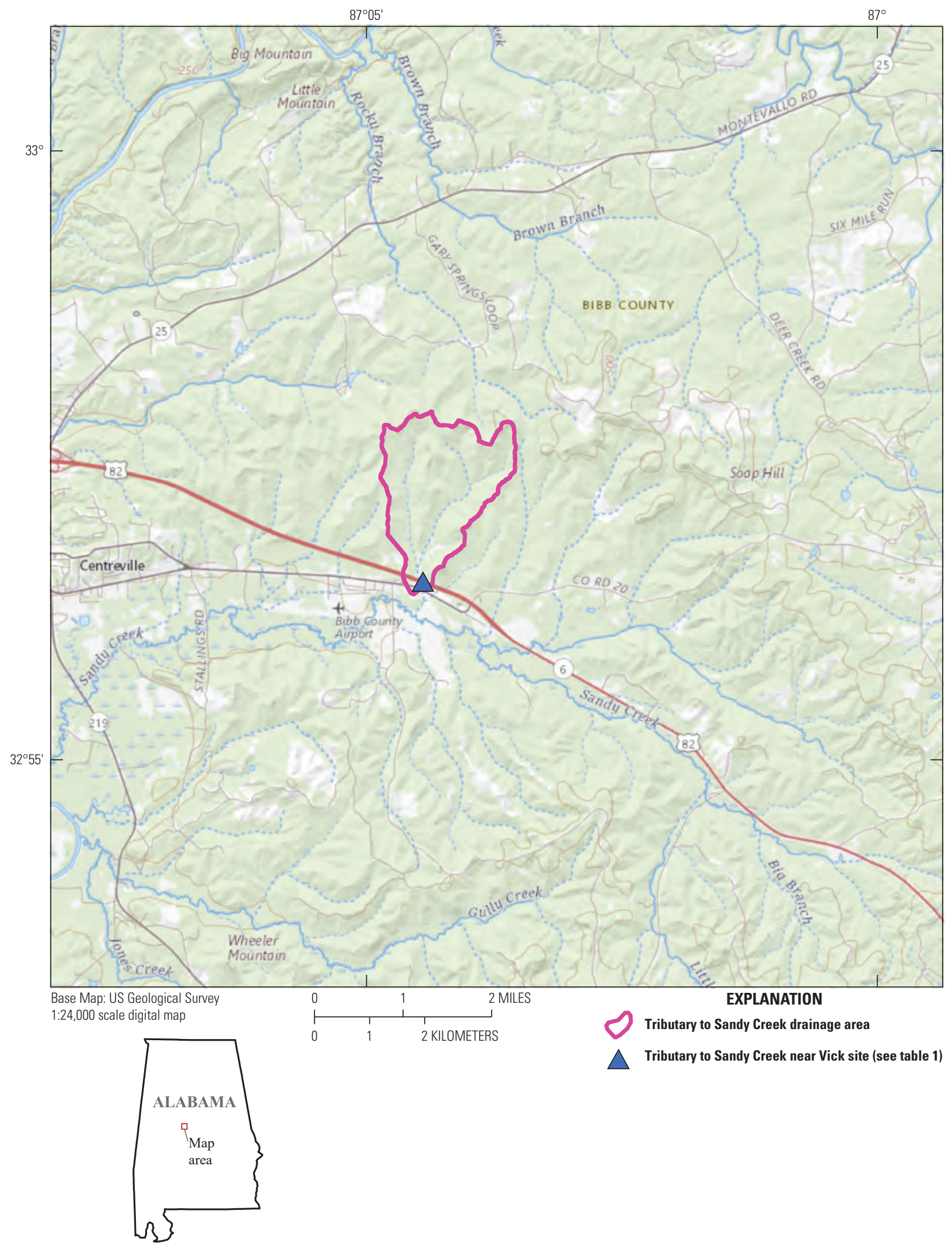

Figure 7. Location of Tributary to Sandy Creek near Vick (site 3) and the associated drainage area. 


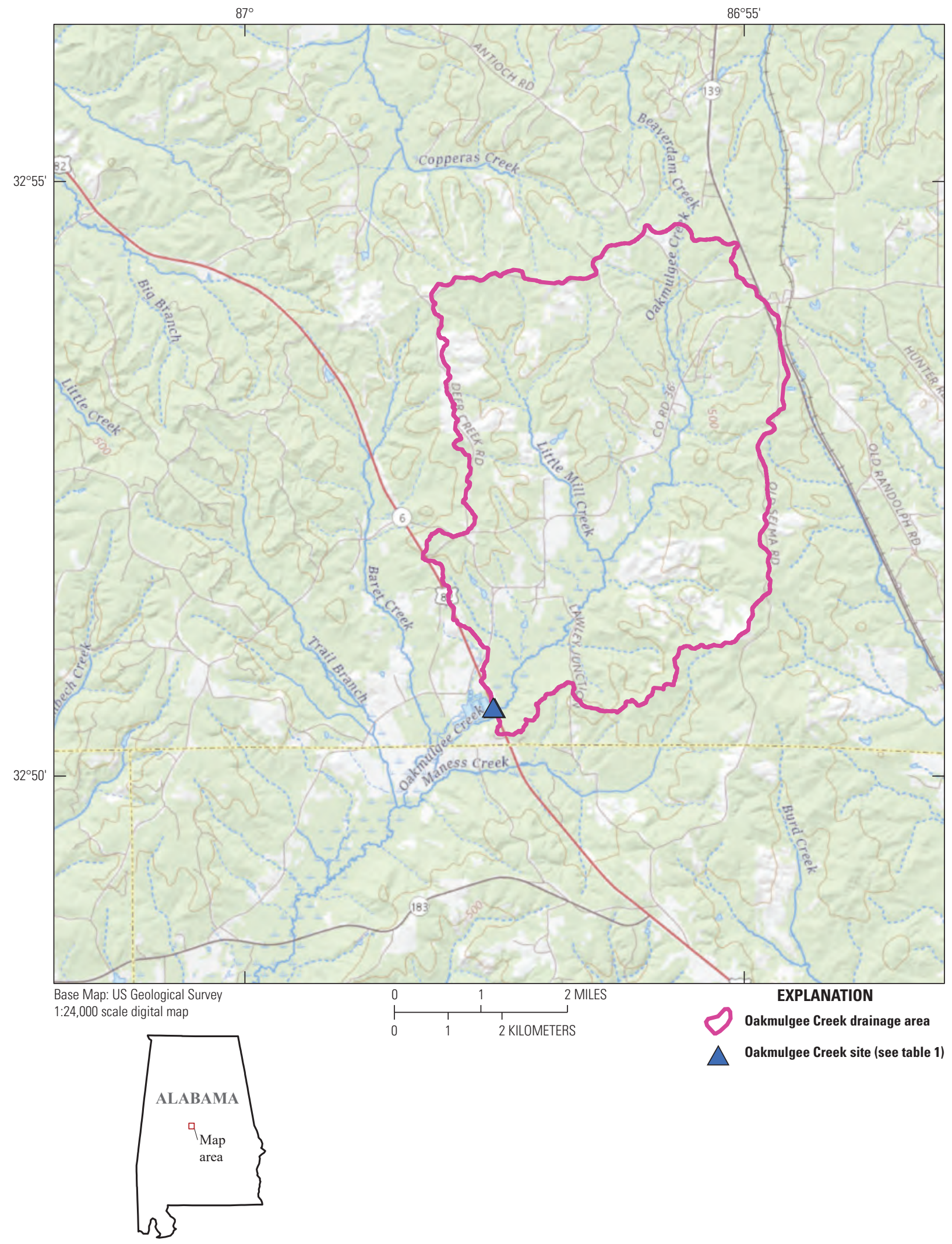

Figure 8. Location of Oakmulgee Creek near Lawley (site 4) and the associated drainage area. 
In 2011, 54.3 percent of the drainage area was forest, and 30.1 percent was grassland/shrub (tables 7 and 8). The estimated 2-year peak streamflow is $879 \mathrm{ft}^{3} / \mathrm{s}$ (table 6). Between October 2013 and March 2015, a triple barrel cast-in-place, concrete box culvert was constructed at the site to replace an existing bridge (table 2 ).

\section{Stream Channel Geometry}

At the Oakmulgee Creek study site, no statistically significant changes in the channel geometry parameters occurred (tables 9 and 10). Note there was substantial change in the downstream thalweg profile shape and point elevations from before- to after construction. Differences in the downstream thalweg point elevations ranged from $-0.6 \mathrm{ft}$ to $3.5 \mathrm{ft}$. (fig. 4H). The change in downstream thalweg profile shape and point elevations (fig. $4 H$ ) indicate that a head cut was propagating upstream through the downstream reach. The 2010 thalweg elevations suggest a head cut had progressed upstream to between the 225 - $\mathrm{ft}$ and $250-\mathrm{ft}$ downstream stationing, and the 2016 thalweg elevations suggest the head cut had continued to propagate upstream to near the $100-\mathrm{ft}$ downstream stationing (fig. 4H).

\section{Streamflow, Sediment, and Turbidity}

At the Oakmulgee Creek study site, streamflow was measured, and samples were collected during all three phases of construction, representing a variety of streamflow magnitudes (table 13). The before-construction, upstream to downstream mean paired sample ratios indicate that sediment concentrations and turbidity were both greater upstream (1.36 and 1.37, respectively) (table 12). This suggests that the construction reach was trapping sediment. The during-construction mean paired sample ratios indicate that sediment concentrations and turbidity were both greater upstream (1.79 and 1.20, respectively) (table 12), suggesting the construction reach was still trapping sediment. The after-construction mean paired sample ratios indicate that sediment concentrations and turbidity were nearly equal upstream and downstream $(0.90$ and 1.10 , respectively) (table 12). This suggests that suspended sediment was efficiently passing through the construction reach after construction.

\section{Northington Branch Near Detroit - Site 5}

The Northington Branch site is in Lamar County, northwestern Alabama, approximately 1.8 miles west of Detroit, Ala., on County Road 5 (figs. 1 and 9). Northington Branch is part of the Mobile-Tombigbee subregional hydrologic unit (fig. 3; table 5). The drainage area above the study site is $6.22 \mathrm{mi}^{2}$ (table 1). In 2011, 66.9 percent of the drainage area was forest, and 21.2 percent was grassland/shrub (tables 7 and 8). The estimated 2-year peak streamflow is $555 \mathrm{ft}^{3} / \mathrm{s}$ (table 6).
Between October 2011 and April 2013, a triple barrel castin-place, concrete box culvert was constructed to replace an existing bridge (table 2).

\section{Stream Channel Geometry}

At the Northington Branch site, the only statistically significant change in the channel geometry parameters was in the downstream mean depth $(-0.20 \mathrm{ft}$ ) (tables 9 and 10). Note that the before-construction, upstream reach thalweg slope was inverted (table 10). The inverted before-construction, upstream reach thalweg slope suggests a streamflow obstruction in the upstream part of the construction reach, trapping sediment in the downstream part of the upstream reach. After construction, the upstream reach thalweg returned to a normal slope, suggesting the streamflow obstruction was removed during construction and sediments in the upstream reach mobilized. Concurrently, sediment was trapped in the downstream reach, resulting in the observed reduction in mean depth (table 9).

\section{Streamflow, Sediment, and Turbidity}

At the Northington Branch site, measurements and samples were collected during one storm event in the beforeconstruction phase and three storm events in the afterconstruction phase (table 13). Maximum measured storm streamflows were similar for both phases of construction (table 13). The before-construction, upstream to downstream mean paired sample ratios indicate that sediment concentrations and turbidity were both greater downstream $(0.41$ and 0.84 , respectively) (table 12). This suggests that sediment was being mobilized as the streamflow passed through the construction reach. The after-construction mean paired sample ratios indicate that sediment concentrations were greater downstream (0.81) while turbidity was greater upstream (1.33) (table 12). This suggests that the larger particles of suspended sediment (sand) were being mobilized within the construction reach while smaller colloidal particles (silt, clay, and organic material) were being trapped within the construction reach after construction.

\section{Lye Branch Near Duncanville - Site 6}

The Lye Branch site is in Tuscaloosa County, northwest central Alabama, approximately 3.5 miles northeast of Duncanville on Hargrove Road (figs. 1 and 10). Lye Branch is part of the Mobile-Tombigbee subregional hydrologic unit (fig. 3; table 5). The drainage area above the study site is $16.4 \mathrm{mi}^{2}$ (table 1). In 2011, 66.2 percent of the drainage area was forest, and 24.6 percent was grassland/shrub (tables 7 and 8). The estimated 2-year peak streamflow is $1,060 \mathrm{ft}^{3} / \mathrm{s}$ (table 6). Between November 2013 and December 2018, a quadruple barrel cast-in-place, concrete box culvert was constructed to replace an existing bridge (table 2). 


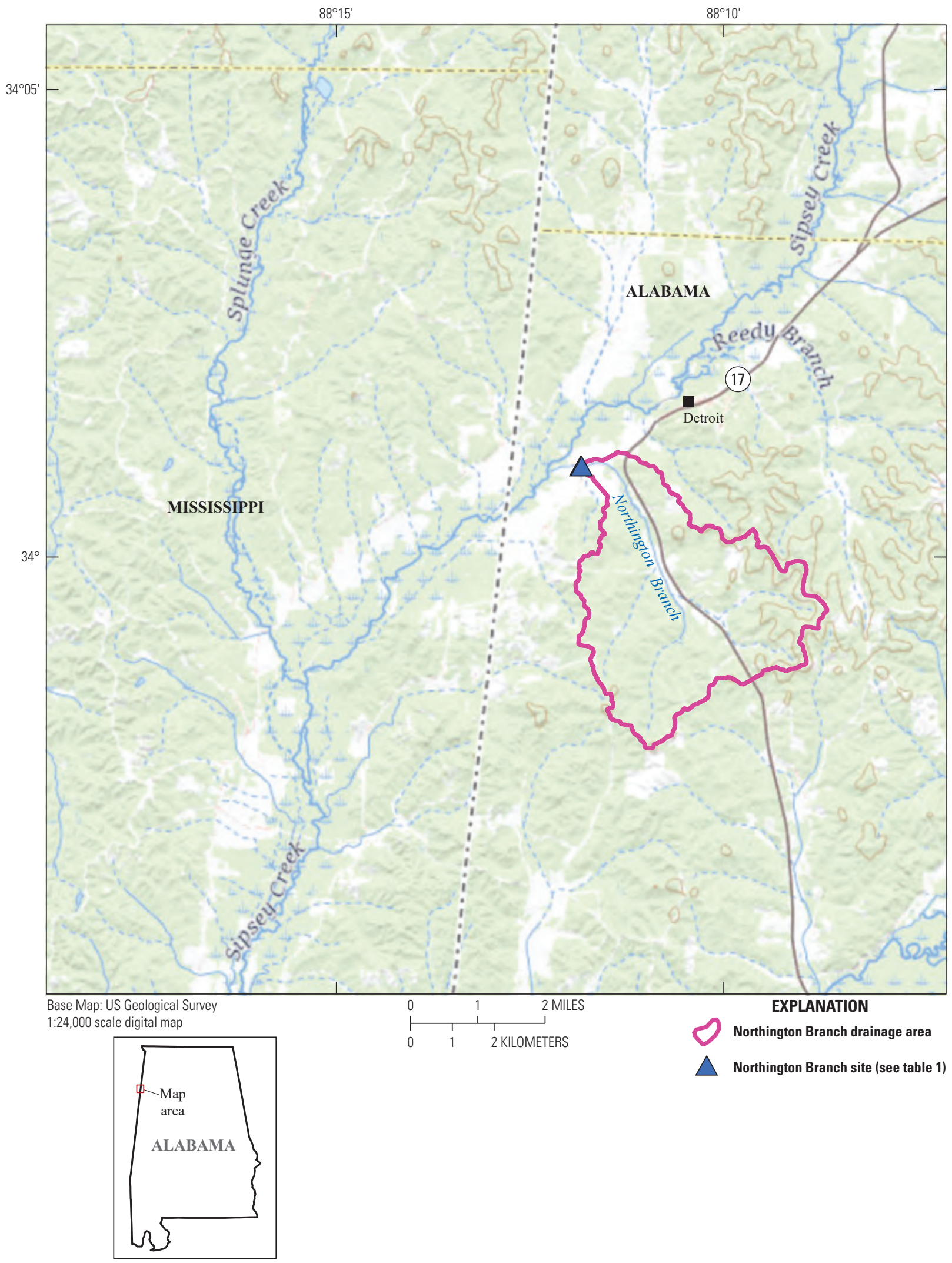

Figure 9. Location of Northington Branch near Detroit (site 5) and the associated drainage area. 


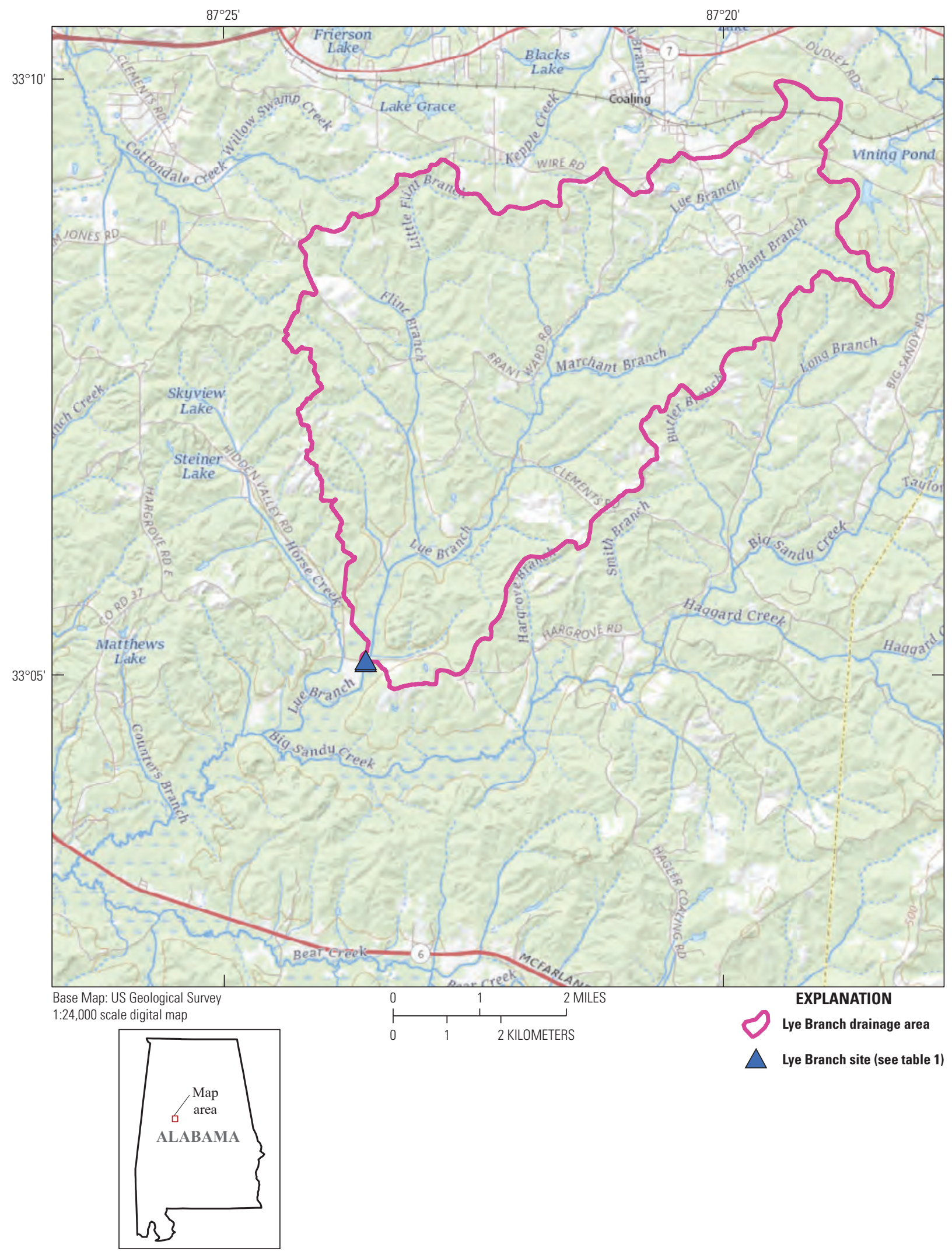

Figure 10. Location of Lye Branch near Duncanville (site 6) and the associated drainage area. 
In addition to the culvert construction, other anthropogenic activities occurred near the Lye Branch site. Comparison of the May 5, 2014, imagery from Google Earth, with imagery from October 20, 2012, indicates that approximately 20 acres of forest were cleared upstream of the culvert and that the right bank of Lye Branch was cleared for approximately $500 \mathrm{ft}$ downstream of the culvert. Google Earth images of the study reaches are available from Gill and Pugh (2021).

\section{Stream Channel Geometry}

At the Lye Branch study site, statistically significant changes in the channel geometry parameters occurred in the downstream mean depth $(-0.70 \mathrm{ft})$ and the upstream thalweg slope (0.0044) (tables 9 and 10). Note that the beforeconstruction, downstream reach and the after-construction, upstream reach thalweg slopes were inverted (table 10). The after-construction, upstream thalweg elevations measured closest to the culvert were approximately $0.75 \mathrm{ft}$ higher than the before-construction elevations (fig. $4 K$ ). The after-construction, downstream thalweg elevations through the entire reach were approximately $1.3 \mathrm{ft}$ higher than the before-construction elevations (fig. $4 L$ ). The inverted, before-construction, downstream reach thalweg slope suggests that a channel obstruction downstream of the downstream study reach caused sediment deposition in the lower part of the reach, resulting in the observed inverted reach thalweg slope. The increased thalweg elevations and inverted thalweg slope in the after-construction, upstream reach suggests a channel obstruction within the construction reach, possibly remnants of the temporary detour bridge built, used, and removed during the construction of the culvert. The increased thalweg elevations throughout the after-construction, downstream reach suggest that the channel obstruction downstream of the reach continued to cause sediment deposition, correcting the downstream reach thalweg slope and reducing the mean depth as noted in the stream geometry t-test results (table 9).

\section{Streamflow, Sediment, and Turbidity}

At the Lye Branch study site, samples were collected during eight storm events - two before construction, three during construction, and three after construction (table 13). Streamflow was not measured during three of the storm events, one in each of the construction phases. Measured maximum streamflows during storm events ranged from 29.9 to $179 \mathrm{ft}^{3} / \mathrm{s}$ (table 13). The before-construction, upstream to downstream mean paired sample ratios indicate that sediment concentrations were nearly equal (1.09), but the turbidity was greater upstream (1.13) (table 12). This suggests the construction reach was trapping colloidal sediment (silt, clay, and organic matter) before construction. The during-construction mean paired sample ratios indicate that sediment concentrations were greater upstream (1.27), but the turbidity was greater downstream (0.86) (table 12). This suggests that the larger particles of suspended sediment (sand) were being trapped within the construction reach while smaller colloidal particles (silt, clay, and organic material) were being mobilized within the construction reach. The after-construction mean paired sample ratios indicate that sediment concentrations were greater upstream (1.30), and the turbidity was nearly equal (1.02) (table 12). This suggests that the larger sediment particles (sand) were mobilized from the construction reach after construction.

\section{Benthic Macroinvertebrate Analysis}

The analysis of benthic macroinvertebrate community metrics is organized into a project-wide evaluation and site-bysite evaluations. First, samples from all study sites were pooled into before- and after-construction groups to evaluate the project-wide consistency of community changes between the two periods. Second, because some of the observed variation in communities is a natural response to the unique habitat, flow, riparian zone, and other conditions of each stream, upstream to downstream comparisons for communities at each site were examined to determine if local effects of culvert construction were evident.

Macroinvertebrate abundance and taxa richness varied among the study sites. Total abundance of macroinvertebrates in a single sample ranged from a maximum of more than 1,000 organisms to a minimum of 33 individuals. Ephemeroptera, Plecoptera, and Trichoptera (EPT) abundance ranged from 3 to almost 600 individuals per sample (fig. 11; Gill and Pugh, 2021). Taxa richness at all sites ranged from 20 to 46 taxa per sample (fig. 12). EPT taxa richness ranged from a single taxon in one sample to a maximum of 14 taxa (fig. 12).

At least 81 percent of identified taxa in the study streams had IDAS-assigned national TVs, and at least 82 percent of benthic macroinvertebrate abundance from each sampled community was assigned a national TV. Average community TVs from all sites were between 4 and 7, which is considered moderately tolerant (fig. 13; Cuffney and Brightbill, 2010; Barbour and others, 1999). Average abundance-weighted TVs for all reaches and all time periods ranged from 4.07 at the Oakmulgee Creek downstream reach to 6.95 at the Tributary to Cahaba upstream reach (fig. 13A). Average richness-based TVs ranged from a low of 4.47 at the Lye Branch upstream reach in the after-construction phase to a high of 6.20 at the Tributary to Cahaba upstream reach in the during-construction phase (fig. 13B).

The Wilcoxon rank sum test results indicated that there was little variation between before- and after-construction periods in the upstream to downstream difference in community metrics. Total abundance, total taxa richness, EPT abundance and taxa richness, and abundance-weighted and richness-based average tolerance values did not have statistically significant differences in the pooled analysis (table 17); however, graphs of these metrics (figs. 11-13) and related habitat and waterquality data (tables 14 and 16) reveal some differences in reach characteristics that are discussed individually for each site. 
Table 17. Metrics calculated by IDAS and Wilcoxon rank sum statistics to test for significance of differences between before-construction and after-construction variation for metric values in upstream and downstream reaches at selected sites in Alabama.

[IDAS, U.S. Geological Survey Invertebrate Data Analysis System (Cuffney and Brightbill, 2010); Wilcoxon rank sum statistics are not significant (p<0.5); $\%$, percent]

\begin{tabular}{|c|c|c|c|c|}
\hline Metric description & $\begin{array}{c}\text { Metric } \\
\text { abbreviation }\end{array}$ & $\begin{array}{l}\text { Wilcoxon } \\
\text { rank sum } \\
\text { statistic }\end{array}$ & $\begin{array}{c}\text { Metric } \\
\text { abbreviation }\end{array}$ & $\begin{array}{c}\text { Wilcoxon } \\
\text { rank sum } \\
\text { statistic }\end{array}$ \\
\hline \multicolumn{5}{|c|}{ Abundance and percent abundance metrics } \\
\hline & Abundance & & $\%$ Abundance & \\
\hline Total number of organisms in the sample & ABUND & 14 & & \\
\hline Abundance of Ephemeroptera, Plecoptera, and Trichoptera & EPT & 15 & EPTp & 15 \\
\hline & Richness & & \%Richness & \\
\hline Total richness (number of taxa) & $\mathrm{RICH}$ & 13 & & \\
\hline Number of Ephemeroptera, Plecoptera, and Trichoptera taxa & EPTR & 13.5 & EPTRp & 14 \\
\hline \multicolumn{5}{|c|}{ Tolerance metrics } \\
\hline $\begin{array}{l}\text { Abundance-weighted mean taxa tolerances: } \\
\qquad \sum_{i=1}^{N} \frac{T V i A i}{N} \begin{array}{l}\text { where } T V i \text { is the tolerance value of taxon " } i, " A i \text { is the } \\
\text { abundance of taxon " } i, \text {, and } N \text { is the number of taxa in } \\
\text { the sample (Hilsenhoff biotic index) }\end{array}\end{array}$ & AbundTOL & 17 & & \\
\hline
\end{tabular}

Different richest-targeted habitats were chosen for the before-construction and after-construction samples because of site conditions. All before-construction samples included collections from overhanging or submerged roots, whereas many of the after-construction samples included collections from riffle areas and woody snags. The differences in richest-targeted habitats between the two sampling periods may explain the lack of a statistically significant change in upstream to downstream differences in community metrics between the beforeconstruction and after-construction sampling periods. Future studies of these sites might benefit from the use of standardized artificial substrates to minimize the variability of sampled benthic communities within and between sites due to differences in sampled substrates.

Bland-Altman plots for the metrics reveal some overall patterns in upstream to downstream differences for a few metrics (figs. 14-16). In agreement with the Wilcoxon rank sum analysis (table 17), the plots show that for total abundance, total richness, EPT richness, and richness-based average tolerance, all differences between upstream and downstream for before- and after-construction periods were within the two standard deviations of the mean difference. Upstream to downstream differences in EPT abundance at the Northington Branch site in 2014 (fig. 14B) and in abundance-weighted tolerance at the Tributary to Cahaba River site in 2017 (fig. 16A) were outside of the limits of agreement.
In general, upstream to downstream differences in total abundance were near zero, with slightly more abundance in the upstream reaches for most sites and sampling periods (fig. 14A). Lye Branch had more organisms downstream than upstream in the before-construction sample and similar counts in both reaches in the after-construction sampling period. In 2014, Northington Branch had much more abundance in the upstream reach than in the downstream reach. EPT abundance was also similar between each set of reaches for almost all the sampling sites and time periods (fig. 14B). Only the EPT abundance in Northington Branch samples in 2014 differed greatly between reaches, with about 500 more EPT organisms in the upstream reach.

Total richness only varied by an average of 1.56 taxa between upstream and downstream reaches (fig. 15A). Northington Branch was the most variable site in terms of total taxa richness, having 10 more taxa in the downstream reach than in the upstream reach in 2014 and 16 more taxa in the upstream reach than in the downstream reach in 2017. Differences between upstream and downstream total richness at most other sites and sample sites were within five taxa (fig. 15A). EPT taxa richness was slightly greater in the upstream reaches than in the downstream reaches for almost all samples (fig. 15B), both before and after construction, which indicates that the differences were not related to new culvert construction. 

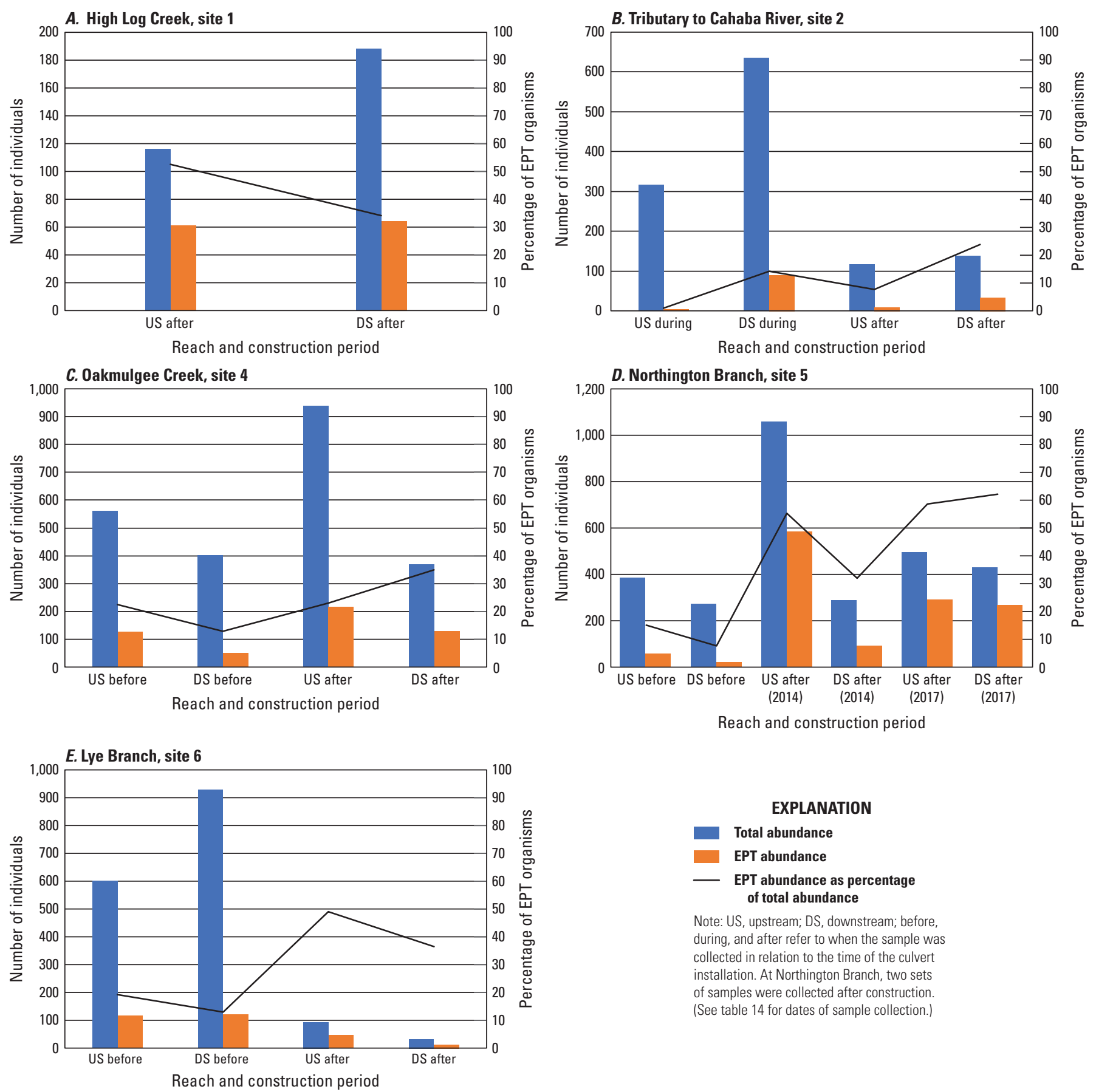

EXPLANATION

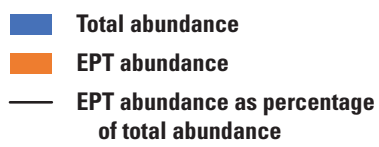

Note: US, upstream; DS, downstream; before, during, and after refer to when the sample was collected in relation to the time of the culvert installation. At Northington Branch, two sets of samples were collected after construction. (See table 14 for dates of sample collection.)

Figure 11. Total abundance of benthic macroinvertebrates, abundance of Ephemeroptera, Plecoptera, and Trichoptera (EPT) organisms, and EPT abundance as a percentage of total abundance in before-, during-, and after-construction samples collected from reaches upstream and downstream of new culvert installations at selected sites in Alabama.

Abundance-weighted TVs differed very little between upstream and downstream reaches, with a mean difference of nearly zero (fig. 16A). The samples collected from the Tributary to Cahaba River site (during and after construction) differed the most between reaches, with upstream average TVs slightly higher than downstream TVs. Richness-based average TVs were more likely to be higher downstream than upstream, but the differences were small for most sites (fig. 16B). Richness-based TVs for the Tributary to Cahaba River site in 2011 (during construction) were higher upstream than downstream.

The upstream to downstream differences for the duringconstruction sample collected from the Tributary to Cahaba River site in 2011 plotted outside of the limits of agreement on 

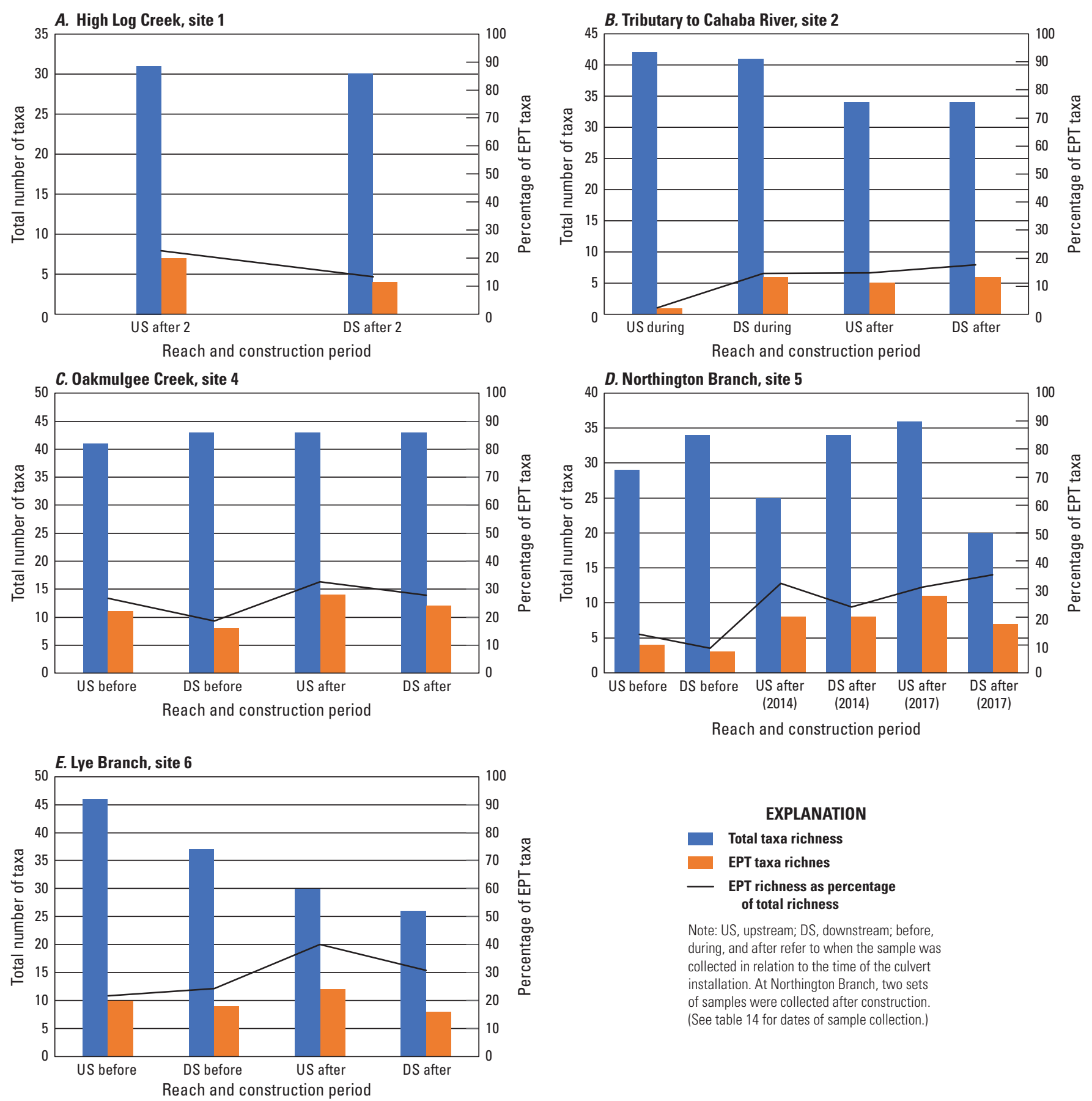

Figure 12. Total taxa richness, Ephemeroptera, Plecoptera, and Trichoptera (EPT) taxa richness, and EPT richness as a percentage of total richness in before-, during-, and after-construction samples collected from reaches upstream and downstream of new culvert installations at selected sites in Alabama.

the EPT richness, abundance-weighted TV, and richness-based TV Bland-Altman plots (figs. 15B, $16 A$ and $B$ ). The difference in EPT taxa richness plotted below the lower limit of agreement for EPT richness, and differences in both tolerance metrics were above their respective upper limits of agreement. These results indicate that during road construction at this site the benthic macroinvertebrate community at the downstream reach had more EPT taxa and less tolerant taxa than the upstream reach. Sediment and water-quality control measures used during construction appear to have adequately prevented degradation to the benthic macroinvertebrate community in the downstream reach. 

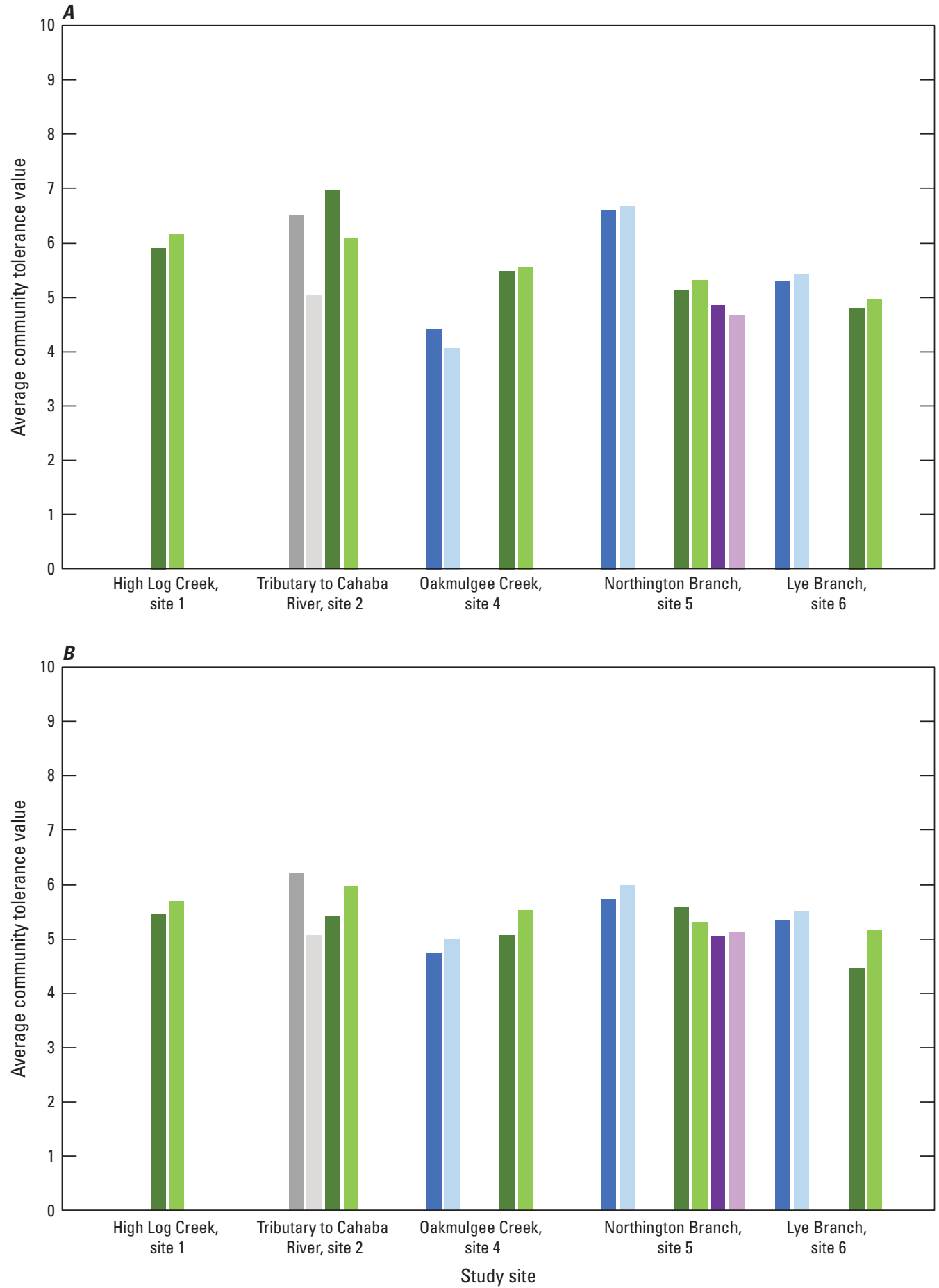

EXPLANATION

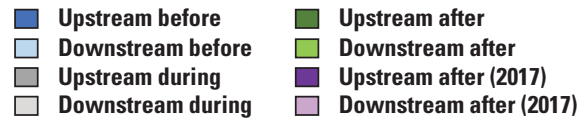

Note: Before, during, and after refer to when the sample was collected in relation to the time of the culvert installation.

At Northington Branch, two sets of samples were collected after construction. (See table 14 for dates of sample collection.)

Figure 13. Average community tolerance values based on $A$, total abundance and $B$, taxa richness in benthic macroinvertebrate community samples collected at selected culvert installation sites in Alabama. 

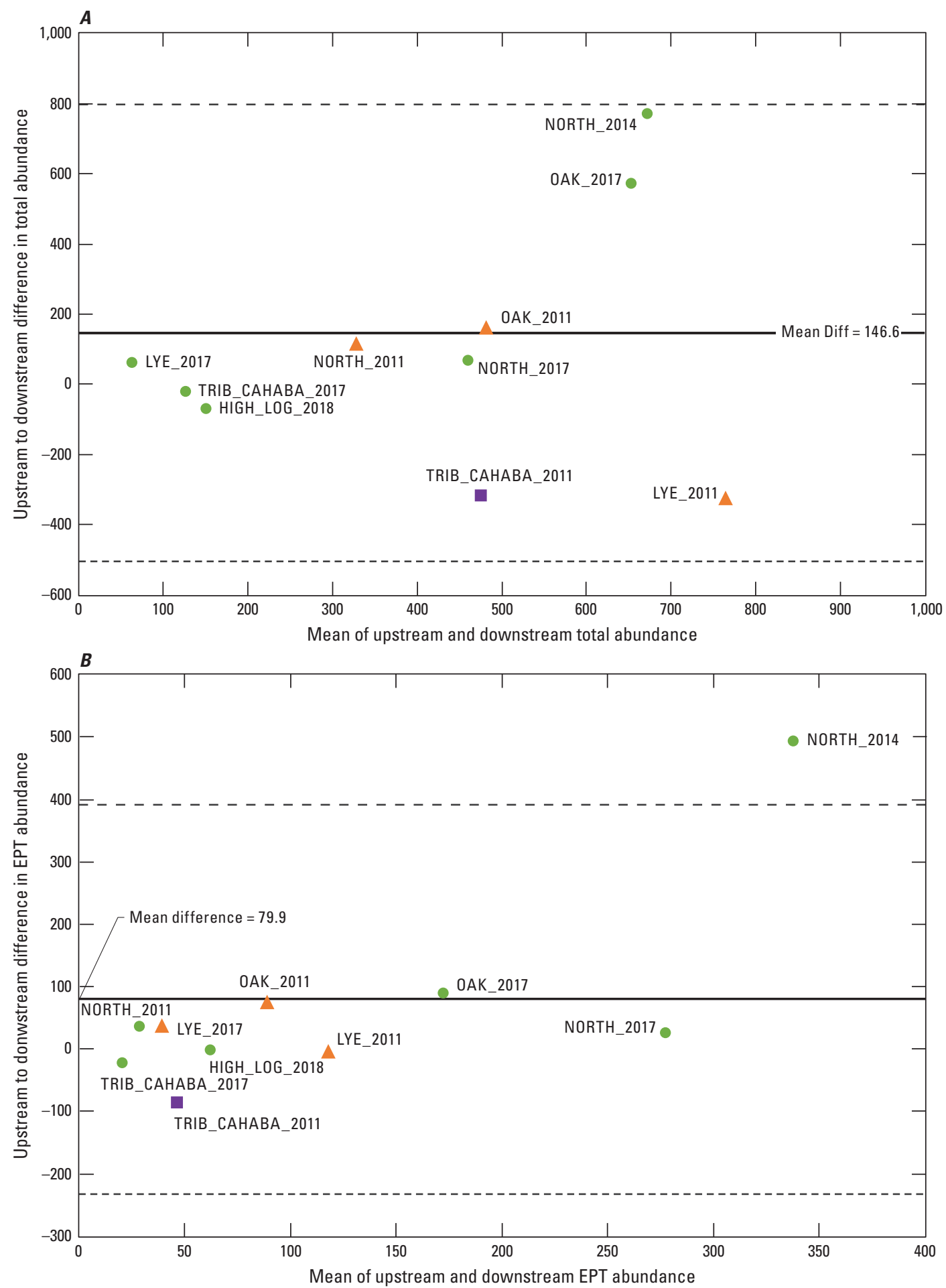

EXPLANATION

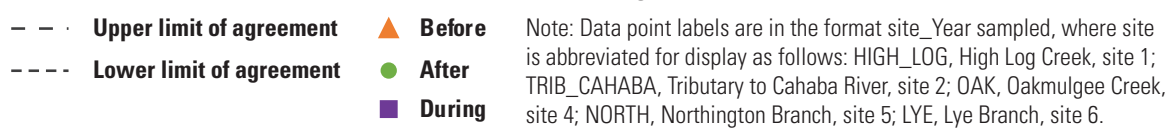

Figure 14. Bland-Altman plots showing differences in $A$, total abundance and $B$, Ephemeroptera, Plecoptera, and Trichoptera (EPT) abundance in benthic macroinvertebrate samples collected before, during, and after culvert installation from upstream and downstream of selected culverts in Alabama. 

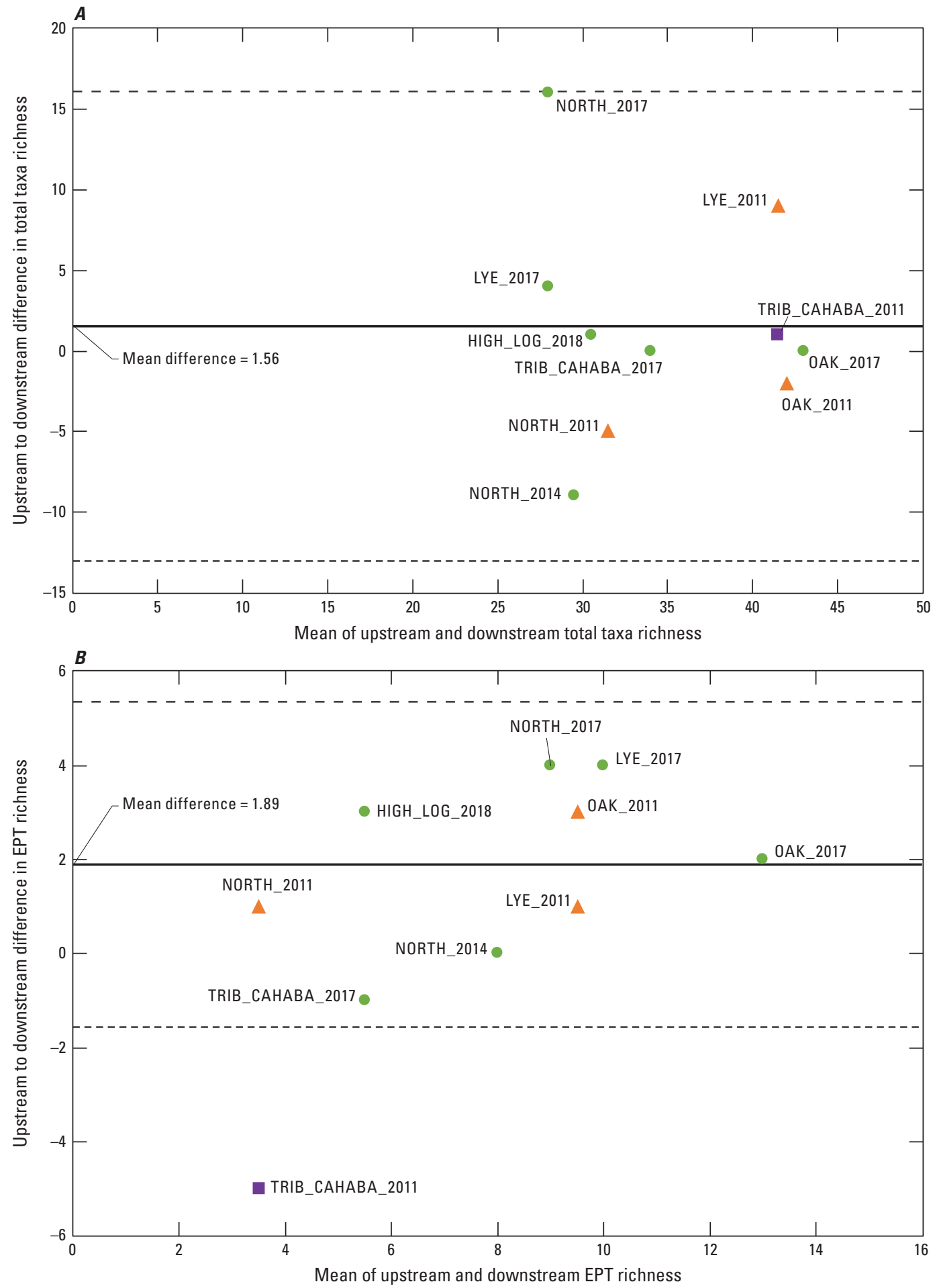

EXPLANATION

- - Upper limit of agreement

- - - Lower limit of agreement
Before

- After

During
Note: Data point labels are in the format site_Year sampled, where site is abbreviated for display as follows: HIGH_LOG, High Log Creek, site 1; TRIB_CAHABA, Tributary to Cahaba River, site 2; OAK, Oakmulgee Creek, site 4; NORTH, Northington Branch, site 5; LYE, Lye Branch, site 6.

Figure 15. Bland-Altman plots showing differences in $A$, total richness and $B$, Ephemeroptera, Plecoptera, and Trichoptera (EPT) richness in benthic macroinvertebrate samples collected before, during, and after culvert installation from upstream and downstream of selected culverts in Alabama. 

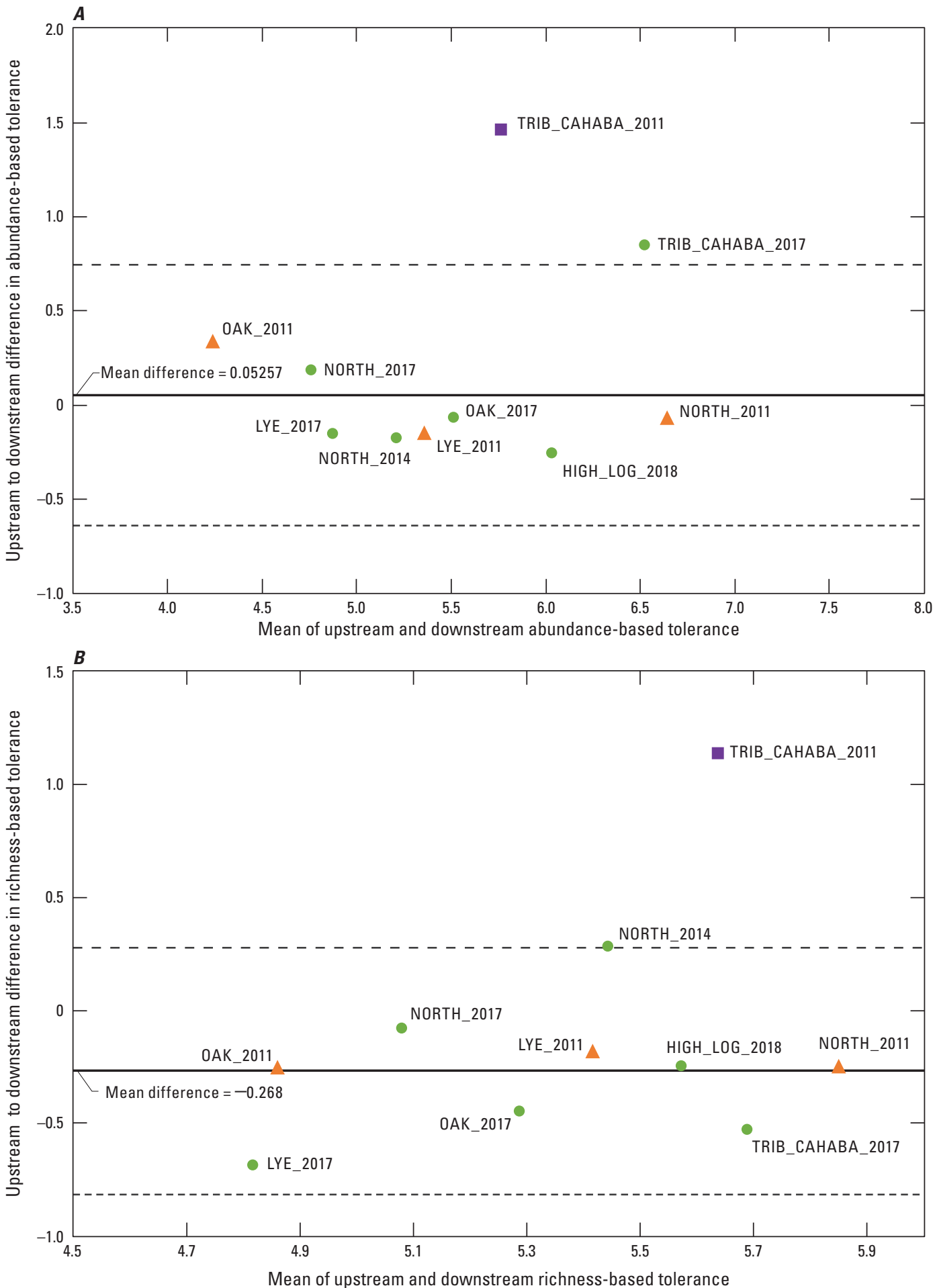

EXPLANATION

- - Upper limit of agreement

- - - - Lower limit of agreement
Before

After

During
Note: Data point labels are in the format site_Year sampled, where site is abbreviated for display as follows: HIGH_LOG, High Log Creek, site 1; TRIB_CAHABA, Tributary to Cahaba River, site 2; OAK, Oakmulgee Creek, site 4; NORTH, Northington Branch, site 5; LYE, Lye Branch, site 6.

Figure 16. Bland-Altman plots showing differences in $A$, abundance-weighted tolerance values and $B$, richness-based tolerance values for samples collected before, during, and after culvert construction from upstream and downstream of selected culverts in Alabama. 


\section{High Log Creek Near Hatchechubbee - Site 1}

High Log Creek was only sampled once, after construction, and only minimal differences in benthic macroinvertebrate community characteristics were observed between the upstream and downstream reaches at the site. Woody snags were identified as the richest habitat in common between the upstream and downstream reaches (table 14). Though overall habitat scores from the two reaches were similar, indicating marginal conditions (table 16), the upstream reach was mainly a large pooled area with slower, deeper water impounded by a beaver dam built on top of limestone riprap just upstream of the culvert. The impoundment and limestone were not present during a before-construction site visit. The only riffles present during the sample collection were caused by fill material near the road. Water-quality field parameters were measured only at the downstream reach and indicated well-oxygenated conditions and a specific conductance value that was higher than values measured at most of the other study sites (table 14).

Total abundance was slightly higher in the downstream reach than in the upstream reach, but EPT abundance was almost equal between the two reaches (fig. 11A). A total of 31 taxa were identified in the sample collected from the upstream reach, and 30 taxa were identified in the sample collected from the downstream reach (fig. 12A). EPT taxa richness was slightly greater in the sample from the upstream reach than in the sample from the downstream reach. The most abundant taxon in both samples was Caenis sp., a genus of mayfly.

Average TVs were similar for benthic macroinvertebrate communities in the upstream and downstream reaches. The downstream reach community had a slightly higher TV by both richness and abundance-weighted tolerance methods (fig. 13). The moderately tolerant class comprised about 75 percent of total abundance at both reaches (Gill and Pugh, 2021; Cuffney and Brightbill, 2010). Almost 15 percent of the total organisms at the upstream site were considered intolerant, while only about 10 percent of the total organisms at the downstream site were intolerant.

The benthic macroinvertebrate community at the High Log Creek site did not appear to be affected by the culvert construction. Even though differences in habitat and localized additions of road construction materials were observed onsite at High Log Creek, most differences in community structure and health metrics were minimal between the reaches upstream and downstream of the culvert. The upstream reach did have a few more EPT taxa than the downstream reach (fig. 12A), which was a pattern at most study sites both before and after culvert construction (fig. 15B).

\section{Tributary to Cahaba River Near Centreville - Site 2}

Samples were collected at the Tributary to Cahaba River site in 2011 and 2017. The samples collected in 2011 were considered during-construction samples because active roadbuilding was ongoing around the newly installed culvert. The samples collected in 2017 represented after-construction conditions. The total habitat scores recorded in 2017 were considered suboptimal and were greater for the reaches at the Tributary to Cahaba River site than at other study site (tables 15 and 16), indicating that habitat conditions may support a healthier macroinvertebrate community. Sampled instream habitats in 2011 were root/bank and woody debris, but in 2017, sampled habitats included riffles as well as root/ bank jabs (table 14). Water-quality parameters recorded in 2017 indicated lower dissolved oxygen and higher specific conductance in the downstream reach than in the upstream reach (table 14). The change in specific conductance was likely due to the presence of limestone around the culvert and road installation.

Total abundance was much greater in the samples collected in 2011 than in the samples collected in 2017 and was greater in samples from the downstream site during both periods (fig. 11B). EPT abundance was very low at the upstream reach, both during and after construction, accounting for only about 1 percent of total abundance during road construction and less than 8 percent after construction. Total taxa richness was similar in samples from upstream and downstream reaches during each of the sampling periods but was greater in the samples collected during construction (fig. 12B). EPT richness was much lower in the sample from the upstream reach than in the sample from the downstream reach during construction, but in the after-construction samples, EPT richness was similar for samples collected upstream and downstream (fig. 12B).

Among all the study sites, the greatest differences in mean TVs between upstream and downstream reaches were measured in the during-construction phase at the Tributary to Cahaba River site (figs. 13 and 16). The richness-based and abundance-weighted TVs indicated a more tolerant benthic macroinvertebrate community upstream than downstream in the during-construction phase.

Richness-based and abundance-weighted TVs for afterconstruction samples still indicated differences between the upstream and downstream reaches, but richness-based TVs indicated a slightly more tolerant community downstream, while abundance-weighted TVs indicated the upstream community was more tolerant (figs. 13 and 16). The difference in abundance-weighted TVs between the upstream and downstream reaches at the Tributary to Cahaba River site in 2017 was more than 2 standard deviations from the mean reach difference for all before- and after-construction samples (fig. 16A). Though this reach difference was an outlier value, it represented lower tolerance in the downstream reach than in the upstream reach. Lower TVs downstream of the culvert indicate that the culvert is not detrimentally affecting benthic macroinvertebrate communities at the site.

Most measures of benthic community health in the upstream and downstream reaches at the Tributary to Cahaba River site after construction were the same or better in the reach downstream of the new culvert, indicating no 
detrimental effects from the culvert construction. Richnessbased TVs in this period, however, did indicate that the downstream community may have changed to become more tolerant of disturbance. Interestingly, data collected in 2011 during roadbuilding also seem to indicate that active construction did not negatively affect the benthic communities; abundance and taxa richness were similar or greater than in samples collected after construction was complete.

\section{Oakmulgee Creek Near Lawley - Site 4}

Habitat scores at Oakmulgee Creek indicated overall suboptimal conditions in both reaches (tables 14 and 15). The upstream reach had slightly better conditions, including well-vegetated banks and a more intact riparian zone. Waterquality field parameters recorded in 2017 were nearly identical between the reaches (table 14).

Total abundance in the after-construction sample from the upstream reach was greater than in the before-construction sample. Total abundance in samples collected from the downstream reach was similar in the before- and after-construction samples but was less than the total abundance in upstream samples during both before- and after-construction periods (fig. 11C). EPT abundance was also greater in upstream samples than the downstream samples but was slightly greater in both samples collected in the after-construction period (fig. 11C). The greater abundances in the upstream reach were consistent with the better habitat score (table 16) for the upstream reach than for the downstream reach.

Total taxa richness in the Oakmulgee samples were nearly identical in both reaches and time periods and ranged from 41 to 43 taxa (fig. 12C). The EPT taxa, which are commonly expected to be relatively intolerant to pollution, increased in taxa richness from the before-construction to the after-construction samples (fig. 12C). EPT taxa richness was greater in the upstream reach than in the downstream reach for both time periods (figs. $12 C$ and $15 B$ ).

Community TVs at Oakmulgee Creek were similar in samples from upstream and downstream reaches during both periods but increased slightly in after-construction samples (fig. 13). Before construction, the Oakmulgee Creek site had the lowest abundance-weighted average TVs recorded for study sites. After construction, TVs were similar to TVs at other sites.

Macroinvertebrate communities and water-quality conditions in Oakmulgee Creek did not appear to be affected by the installation of the culvert. Water chemistry, total and EPT macroinvertebrate abundance, and taxa richness indicated only minor differences between samples collected before and after culvert construction. TVs increased for the afterconstruction samples, but these increases were in samples from both reaches.

\section{Northington Branch Near Detroit - Site 5}

Northington Branch was sampled three times during this study: before construction in 2011 and after construction in 2014 and 2017 (table 14). After-construction sampling in 2014 was during a period of abnormally low streamflow, which affected the amount and type of available habitat, so a subsequent sample was collected in 2017 to ensure that the macroinvertebrate community was accurately assessed. In 2011, the habitats sampled were submerged roots and woody debris. Because of the low flows in 2014 and less available submerged woody debris in 2017 , riffle areas were identified as richest available habitats in the after-construction samples.

Total habitat scores recorded at Northington Branch in 2017 were in the marginal category range in the upstream reach and in the lower suboptimal in the downstream reach (tables 15 and 16). The entire area in the vicinity of the culvert had been channelized before this study began, and effects of the channelization on instream habitat and riparian zones were noted as part of the habitat scores. Dissolved oxygen, $\mathrm{pH}$, and specific conductance measurements were similar for the upstream and downstream reaches in 2017 (table 14).

Total and EPT abundance in the sample collected in 2017 were greater than in the before-construction sample collected in 2011 (fig. 11D). In 2014, EPT abundance in the sample from the upstream reach of Northington Branch exceeded the downstream sample's EPT abundance by about 500 organisms, and the difference between the reaches was more than 2 standard deviations from the mean reach difference in EPT abundance for all study sites (fig. 14B). Because the EPT abundance was similar in samples collected from upstream and downstream reaches in 2011 and 2017, the EPT abundance in samples collected in 2014 was most likely affected by other environmental factors and did not represent a lasting response to culvert construction. During sampling in 2014, lower streamflow affected the amount of available habitat, and more area was sampled upstream than downstream. This difference in area sampled in 2014 may explain the much greater total and EPT abundance in the upstream sample (figs. $11 D$ and 14). For all sampling periods, total and EPT abundance at Northington Branch were slightly greater in the upstream reach than in the downstream reach (figs. 11D, and 14A, B).

Before culvert construction, total taxa richness was slightly greater in the downstream reach than in the upstream reach. Total taxa richness was not consistent in the afterconstruction samples; richness was greater in the downstream reach in 2014 and greater in the upstream reach in 2017 (figs. $12 \mathrm{D}$ and $15 \mathrm{~A}$ ). The difference in total taxa richness between the reaches was also greater in the after-construction sampling periods, ranging from 25 taxa upstream to 34 taxa downstream in 2014 and from 20 taxa downstream to 36 taxa upstream in 2017 (figs. 12D and 15A). EPT taxa richness was greater in all samples collected after construction than in the samples collected before construction, possibly because of the difference in sampled habitat type (fig. 12D). 
TVs based on abundance were considerably lower for the samples collected in 2014 and 2017 than for the samples collected in 2011, indicating a less pollution-tolerant community after construction (figs. 13 and 16A, B). Average TVs based on richness varied much less between time periods than those based on abundance. TVs were similar between upstream and downstream reaches for all time periods, indicating that neither the pre-existing bridge nor the new culvert affected the tolerance of the benthic macroinvertebrate communities.

Community measures at Northington Branch were highly variable. Despite the high variability, some apparent patterns in the data allow for an assessment of culvert construction effects. Generally total and EPT abundance were greater upstream than downstream during the before- and afterconstruction periods, indicating that this difference was caused by something other than the culvert. TVs were similar for benthic macroinvertebrate communities upstream and downstream in all sampling periods, but TVs were slightly lower in samples from the after-construction period. This suggests that stream conditions have not degraded because of culvert construction and are adequate to support a community of more intolerant organisms.

\section{Lye Branch Near Duncanville - Site 6}

Instream habitats at Lye Branch differed slightly between the before- and after-construction phases of this study. The stream has a sandy bottom throughout both reaches, and woody snags and submerged roots were the sampled habitats in the before-construction phase (table 14). Only woody snags were sampled after construction (table 14) because sand had shifted to cover some of the exposed root bank areas downstream. Total habitat scores recorded in the after-construction phase (table 16) were in the suboptimal category for both stream reaches, but the upstream reach scored slightly higher than the downstream reach because it had a more stable riparian zone.

Total abundance was much lower in the after-construction phase than in the before-construction phase, but the percentage of EPT abundance was much higher after construction (fig. 11E). Total taxa richness decreased in after-construction samples and was consistently greater in samples from the upstream reach than in samples from the downstream reach (fig. 12E). EPT taxa richness in samples collected from the upstream and downstream reaches before construction only differed by one taxon. After construction, the sample collected from the upstream reach contained 12 EPT taxa, and the sample collected from the downstream reach had eight EPT taxa (fig. 12E).

All TVs were lower for samples collected after construction than for samples collected before construction. Tolerance values were slightly lower in the upstream reach than in the downstream reach for all samples, but the difference was more pronounced for richness-based tolerance in the afterconstruction phase (fig. 13).
Metrics of the benthic macroinvertebrate community at Lye Branch did not show a clear response to culvert construction. Total and EPT abundance and total taxa richness were reduced in the after-construction samples (figs. $11 E$ and $12 E$ ), but patterns of greater abundance and richness in the upstream reach than in the downstream reach were seen in both the before- and after-construction samples. Lower tolerance values in the after-construction samples indicate that the afterconstruction condition of the sampled reaches can support more intolerant organisms (fig. 13).

\section{Limitations of This Study and Lessons Learned}

The purpose of this study was to determine if culvert installations were having lasting measurable effects on stream channel geometry and instream habitats and biota. Challenges of real-world environmental conditions exposed limitations in the study design and methods. Slight changes in methods could provide a considerable improvement in potential future studies of culvert effects. Four changes are proposed: (1) improve topographic survey control, (2) add thalweg longitudinal profile measurements to the topographic survey, (3) collect continuous stage information, and (4) employ the use of artificial substrates for benthic macroinvertebrate collections.

Accurate measurement of stream channel geometry change depends on having a strict definition of site cross sections. The lack of permanent benchmarks at the ends of cross sections resulted in the misalignment of many of the paired, before- and after-construction, topographic surveys of the cross sections. Establishing permanent cross-section endpoints would allow for measurements to be made in exactly the same position each time a survey is made.

Stream channel longitudinal profiles are an important stream geometry parameter to measure. Longitudinal profiles of the thalweg define the channel sinuosity and slope and identify the distribution of streambed forms (for example, cascades, riffles, pools, and dunes). More accurate measurements could be obtained if longitudinal profile measurements were made concurrently with the cross-sectional topographic surveys and started above the most upstream cross section and run continuously through the construction reach, ending below the most downstream cross section.

Collection of continuous stage data based on a set datum for the duration of the study would allow for better distribution of sediment samples throughout storm hydrographs, comparisons of sediment concentration across multiple storm events, and, if a stage/streamflow relation is developed, calculation of sediment loading. A related suggestion for improving collection of stormflow data for sediment analysis is the use of automatic samplers. Some of the larger stream sites in this study became inaccessible at high flows, and samples were not 
always collected to define the peak of the storm hydrograph. Properly sited automatic samplers could continue to collect data throughout storm events.

Ideally, benthic macroinvertebrate community samples would have been collected in replicate to define the intersample variability. Because of constraints in time, funding, and stream size, replicate samples were not collected during this study. Artificial substrates for benthic macroinvertebrate colonization could be used to increase comparable available habitat in the upstream and downstream reaches. The use of a standardized artificial substrate could minimize time spent sampling and provide ample habitat of the same type at each site. Artificial substrates could also provide enough habitat to allow for analysis of replicate samples at each site.

The planned timelines of the construction of culverts and other civil structures often change. Completion of such structures can be delayed or canceled because of changing funding priorities, contracting challenges, materials acquisition or quality issues, and (or) inclement weather. Studies depending on the construction of proposed civil structures may be more effective or efficient with a nimble, flexible timeline to account for the continually changing timelines of these projects.

\section{Summary}

To measure the effects of highway culvert construction on selected stream channel beds, banks, and slopes at six sites in Alabama, topographic surveys of the channel geometry (cross-sectional area, mean depth, top width, and thalweg slope) upstream and downstream of the culvert were conducted by the U.S. Geological Survey, in cooperation with the Alabama Department of Transportation, before and after culvert construction during 2011-19. At the High Log Creek site, the stream geometry data indicate sediment deposition related to the remnants of a cofferdam in the upstream reach. At the Tributary to Cahaba River site, the stream geometry data indicate erosion in the upstream and downstream reaches related to the buried culvert invert design. Erosion in the downstream reach of the Tributary to Sandy Creek site was related to sediment-free water exiting the site. Erosion in the downstream reach of the Oakmulgee Creek site increased as a head cut progressed upstream through the reach. Erosion in the upstream reach of the Northington Branch site helped the reach's slope return to normal; deposition in the downstream reach was evident as the stream continued to adjust to the removal of a pre-construction channel obstruction. Deposition in the upstream and downstream reaches at the Lye Branch site was related to channel obstructions.

To help assess the changes in channel geometry and aquatic ecology, surface-water samples were simultaneously collected for analyses of suspended sediment and turbidity; samples were collected upstream and downstream of the study sites during high-flow events in all three phases of culvert construction. Because streamflow could not be accurately determined during collection of the samples, data analysis focused on the parity of the upstream and downstream sediment concentrations and turbidity for each discrete sample collection time. The mean upstream to downstream paired ratios of sediment concentrations and turbidity data indicate that the High Log Creek construction reach was trapping colloidal particles before construction, mobilizing colloidal particles during construction, and efficiently transporting the creek's sediment load through the reach after construction. The data from the Tributary to Cahaba River site indicate that the construction reach was mobilizing colloidal and noncolloidal sediment during construction and trapping noncolloidal sediment after construction. At the Tributary to Sandy Creek site, the construction reach was trapping noncolloidal sediment and mobilizing colloidal particles during construction and was mobilizing noncolloidal sediment and trapping colloidal particles after construction. The construction reach at the Oakmulgee Creek site was trapping colloidal and noncolloidal sediment before and during construction, and colloidal and noncolloidal sediment was moving efficiently through the reach after construction. The construction reach at the Northington Branch site mobilized colloidal and noncolloidal sediment before construction and mobilized noncolloidal sediment and trapped colloidal sediment after construction. The construction reach at the Lye Branch site was trapping colloidal sediment before construction and was trapping noncolloidal sediment and mobilizing colloidal sediment during and after construction.

Benthic macroinvertebrate sampling results did not strongly indicate that culvert construction caused impairment to communities at study sites. Observed differences in benthic communities between upstream and downstream reaches were relatively small, and the Wilcoxon rank sum test indicated that upstream to downstream variations in total and Ephemeroptera, Plecoptera, and Trichoptera (EPT) abundance, total and EPT richness, and abundance-weighted and richness-based average tolerance values were not statistically different between the before- and after-construction sampling periods. For total abundance, total richness, EPT richness, and richness-based average tolerance, all individual differences between upstream and downstream metrics were within two standard deviations of the mean difference for all upstream to downstream reach pairs for before- and after-construction periods. Differences between upstream and downstream reaches were more than two standard deviations from the mean difference for EPT abundance at the Northington Branch site in 2014 and abundance-weighted tolerance at the Tributary to Cahaba River site in 2017, but neither of these outliers indicated detrimental effects of culvert construction.

Tolerance metrics indicated no major changes in the pollution tolerance of benthic macroinvertebrate communities. Average tolerance values indicated the pollution sensitivity of the benthic macroinvertebrate communities weighted by variation in total abundance and taxa richness. Tolerance values at study sites ranged from about 4 to 7 and indicated moderately pollution-tolerant macroinvertebrate communities. Samples were collected from the Oakmulgee Creek, Northington 
Branch, and Lye Branch sites before and after construction for analysis of benthic macroinvertebrates. Abundance-weighted tolerance values at Oakmulgee Creek were slightly greater for the after-construction samples from both reaches, while afterconstruction values at the Northington Branch and Lye Branch sites were somewhat lower than before-construction values. Upstream to downstream patterns in abundance-weighted tolerance values, however, remained the same between the before-construction and after-construction sampling periods, indicating no evidence of detrimental effects from culvert construction. For richness-based tolerance values at Lye Branch, the difference between upstream and downstream values became more pronounced in the after-construction period with greater average tolerance downstream. The observed increase in tolerance values downstream provides some evidence for potential negative effects from culvert construction at Lye Branch, but both upstream and downstream tolerance values were lower after construction than before.

Changes in the available types of in-stream habitat for before-, during-, and after-construction sampling periods may explain some of the observed variance in measures of benthic macroinvertebrate community composition. Future studies of benthic macroinvertebrate communities at these sites or other sites with new culvert installations could benefit from the use of standardized artificial substrates, more sample replicates during each construction phase, and more frequent and detailed habitat scoring.

\section{Acknowledgments}

The authors would like to acknowledge and thank Scott Hedgecock (USGS, Civil Engineer) for all his efforts in leading, planning, and executing much of the work needed to complete this study. Before Scott's retirement in 2018, he spent parts of 10 years conducting before- and after-construction topographic surveys and chasing storm events at all hours collecting data for this study. Without Scott's commitment, this study would never have come to fruition or completion.

\section{References}

Alabama Department of Environmental Management, 2007, Aquatic macroinvertebrate community wadeable multihabitat bioassessment-organism identification, standard operating procedure \#6002: Alabama Department of Environmental Management, $18 \mathrm{p}$.

Alabama Department of Environmental Management, 2008, Aquatic macroinvertebrate community wadeable multi-habitat bioassessment-sample processing, standard operating procedure \#6001: Alabama Department of Environmental Management, $12 \mathrm{p}$.
Anderson, C.W., 2005, Turbidity: U.S. Geological Survey Techniques of Water-Resources Investigations, book 9, chap. A6.7, 55 p. [Also available at https://doi.org/10.3133/ twri09A6.7.]

Anderson, J.R., Hardy, E.E., Roach, J.T., and Witmer, R.E., 1976, A land use and land cover classification system for use with remote sensor data: U.S. Geological Survey Professional Paper 964, 28 p. [Also available at https://doi.org/10.3133/pp964.]

Barbour, M.T., Gerritsen, J., Snyder, B.D., and Stribling, J.B., 1999, Rapid bioassessment protocols for use in streams and wadeable rivers-Periphyton, benthic macroinvertebrates, and fish (2d. ed.): Washington, D.C., U.S. Environmental Protection Agency, Office of Water, EPA 841-B-99-002, [variously paged], accessed March 1, 2019, at https://www.epa.gov/sites/production/files/2019-02/ documents/rapid-bioassessment-streams-rivers-1999.pdf.

Bland, J.M., and Altman, D.G., 1986, Statistical methods for assessing agreement between two methods of clinical measurement: The Lancet, v. 327, no. 8476, p. 307-310. [Also available at https://doi.org/10.1016/S01406736(86)90837-8.]

Bland, J.M., and Altman, D.G., 1999, Measuring agreement in method comparison studies: Statistical Methods in Medical Research, v. 8, no. 2, p. 135-160.

Bolton, S., and Shellberg, J., 2001, White paper-Ecological issues in floodplains and riparian corridors: Seattle, Wash., University of Washington, Center for Streamside Studies, prepared for Washington Department of Fish and Wildlife, Washington Department of Ecology, and Washington Department of Transportation, Technical Report WA-RD 425.1, 88 p., accessed April 10, 2017, at https://wdfw.wa.gov/publications/00058/.

Brookes, A., 1988, Channelized rivers-Perspectives for environmental management: Chichester, United Kingdom, John Wiley and Sons, $342 \mathrm{p}$.

Chaney, P.L., 2013, Climate-Encyclopedia of Alabama: Auburn University Outreach, Alabama Humanities Foundation, accessed December 10, 2018, at http://www.encyclopediaofalabama.org/article/h-1283.

Chang, F.H., Lawrence, J.E., Rios-Tuoma, B., and Resh, V.H., 2014, Tolerance values of benthic macroinvertebrates for stream biomonitoring-Assessment of assumptions underlying scoring systems worldwide: Environmental Monitoring and Assessment, v. 186, no. 4, p. 2135-2149. [Also available at https://doi.org/10.1007/s10661013-3523-6.]

Cotton, C.A., 1952, Geomorphology an Introduction to the Study of Landforms: New York, John Wiley and Sons, $505 \mathrm{p}$. 
Cuffney, T.F., and Brightbill, R.A., 2010, User's manual for the National Water-Quality Assessment Program Invertebrate Data Analysis System (IDAS) software, version 5: U.S. Geological Survey Techniques and Methods $7-$ C4, 126 p., accessed February 26, 2019, at https://pubs. usgs.gov/tm/7C4/.

Edwards, T.K., and Glysson, G.D., 1999, Field methods for measurement of fluvial sediment: U.S. Geological Survey Techniques of Water-Resources Investigations, book 3, chap. C2, 89 p., accessed April 10, 2017, at https://pubs .usgs.gov/twri/twri3-c2/pdf/TWRI_3-C2.pdf.

Evenson, E.J., Orndorff, R.C., Blome, C.D., Böhlke, J.K., Hershberger, P.K., Langenheim, V.E., McCabe, G.J., Morlock, S.E., Reeves, H.W., Verdin, J.P., Weyers, H.S., and Wood, T.M., 2013, U.S. Geological Survey water science strategy - Observing, understanding, predicting, and delivering water science to the Nation: U.S. Geological Survey Circular 1383-G, 49 p. [Also available at https://doi.org/ 10.3133/cir1383G.]

Fenneman, N.M., 1938, Physiography of the eastern United States: New York, McGraw-Hill Book Co., Inc., 689 p.

Gill, A.C., and Pugh, A.L., 2021, Aerial imagery, benthic macroinvertebrate, topographic survey, and soil survey datasets collected for a study of effects of culverts on the natural conditions of streams in the East Gulf Coastal Plain of Alabama, 2010-2019: U.S. Geological Survey data release, https://doi.org/10.5066/P906BOVO.

Glen, S., 2016, Bland-Altman plot/Tukey mean difference plot, accessed August 10, 2020, at https://www.statistics howto.com/bland-altman-plot/.

Griffith, G.E., Omernik, J.M., Comstock, J.A., Lawrence, S., Martin, G., Goddard, A., Hulcher, V.J., and Foster, T., 2001, Ecoregions of Alabama and Georgia (color poster with map, descriptive text, summary tables, and photographs): Reston, Va., U.S. Geological Survey, 1 sheet, scale 1:1,700,000, accessed December 13, 2019, at http://ecologicalreg ions.info/data/ga/alga_front.pdf.

Hahn, S.S., 1982, Stream channelization; effects on stream fauna, in Greeson, P.E., ed., Biota and biological principles of the aquatic environment: U.S. Geological Survey Circular 848-A, p. 43-49.

Hedgecock, T.S., 2004, Magnitude and frequency of floods on small rural streams in Alabama: U.S. Geological Survey Scientific Investigations Report 2004-5135, 10 p., accessed December 17, 2018, at https://doi.org/10.3133/sir20045135.

Hedgecock, T.S., and Feaster, T.D., 2007, Magnitude and frequency of floods in Alabama, 2003: U.S. Geological Survey Scientific Investigations Report 2007-5204, 28 p., 1 app, accessed December 17, 2018, at https://pubs.usgs.gov/sir/ 2007/5204/.
Horton, R.E., 1945, Erosional development of streams and their drainage basins - Hydrophysical approach to quantitative morphology: Geological Society of America Bulletin, v. 56, no. 3, p. 275-370. [Also available at https://doi.org/ 10.1130/0016-7606(1945)56[275:EDOSAT]2.0.CO;2.]

Hosman, R.L., 1991, Regional stratigraphy and subsurface geology of Cenozoic deposits, Gulf Coastal Plain, southcentral United States: U.S. Geological Survey OpenFile Report 91-66, 43 p., accessed January 16, 2019, at https://doi.org/10.3133/ofr9166.

Jackson, S.D., 2003, Ecological considerations in the design of river and stream crossings, in International Conference on Ecology and Transportation, Lake Placid, N.Y., Proceedings: International Conference on Ecology and Transportation, $29 \mathrm{p}$.

Johansen, K.D., 2003, Design and construction of aquatic organism passage and road-stream crossings - Construction challenges and case studies of stream simulation structures for aquatic organism passage, in International Conference on Ecology and Transportation, Lake Placid, N.Y., Proceedings: International Conference on Ecology and Transportation, $72 \mathrm{p}$.

Leopold, L.B., 1994, A view of the river: Cambridge, Mass., Harvard University Press, 298 p.

Lynch, J.A., Corbett, E.S., and Hoopes, R., 1977, Implications of forest management practices on the aquatic environment: Fisheries, v. 2, p. 16-22.

Mitchell, C.C., Jr., and Loerch, J.C., 2008, Soils of Alabama: USDA-NRCS Cooperative Extension, Auburn University, accessed December 7, 2017, at https://www.nrcs.usda.gov/ wps/portal/nrcs/detail/soils/survey/office/ssr7/?cid= nrcs142p2_047868.

Moulton, S.R., Kennen, J.G., Goldstein, R.M., and Hambrook, J.A., 2002, Revised protocols for sampling algal, invertebrate, and fish communities as part of the National WaterQuality Assessment Program: U.S. Geological Survey Open-File Report 02-150, 75 p., accessed April 1, 2020, at https://doi.org/10.3133/ofr2002150.

National Academies of Sciences, Engineering, and Medicine, 2012, Hydraulic loss coefficients for culverts: Washington, D.C., National Academies Press, 114 p., accessed July 29, 2020, at https://doi.org/10.17226/22673.

Neilson, M., 2016, East Gulf Coastal Plain physiographic section-Encyclopedia of Alabama: Auburn University Outreach, Alabama Humanities Foundation, accessed December 10, 2018, at http://www.encyclopediaofalabama. org/article/h-1256. 
Norman, J.M., Houghtalen, R.J., and Johnston, W.J., 2005, Hydraulic design of highway culverts ( 2 d ed.): U.S. Department of Transportation, Federal Highway Administration, National Highway Institute, Hydraulic Design Series Number 5, Publication No. FHWANHI-01-020, 348 p., December 17, 2018, at https:/www. fs.fed.us/biology/nsaec/fishxing/fplibrary/FHWA_2005 Hydraulic_design_of_highway_culverts.pdf.

Seaber, P.R., Kapinos, F.P., and Knapp, G.L., 1987, Hydrologic unit maps: U.S. Geological Survey, WaterSupply Paper 2294, 20 p., accessed December 11, 2019, at https://pubs.usgs.gov/wsp/wsp2294/.

Soil Survey Staff, Natural Resources Conservation Service, U.S. Department of Agriculture, Web Soil Survey, accessed August 2017 at http://websoilsurvey.sc.egov.usda.gov/.

Strahler, A.N., 1957, Quantitative analysis of watershed geomorphology: Eos, Transactions, American Geophysical Union, v. 38, no. 6, p. 913-920. [Also available at https://doi.org/10.1029/TR038i006p00913.]

Szabo, M.W., Osborne, W.E., Copeland, C.W., Jr., and Neathery, T.L., 1988, Geologic map of Alabama: Geological Survey of Alabama, Special Map 220, 5 sheets, scale $1: 250,000$.

Turnipseed, D.P., and Sauer, V.B., 2010, Discharge measurements at gaging stations: U.S. Geological Survey Techniques and Methods, book 3, chap. A8, 87 p. [Also available at https://pubs.usgs.gov/tm/tm3-a8/.]
U.S. Geological Survey, 2011, National Land Cover Database 2011 (NLCD2011): Multi-Resolution Land Characteristics Consortium (MRLC) online database. [Also available at https://www.mrlc.gov/nlcd2011.php.]

U.S. Geological Survey, 2017, National Hydrography Dataset, ver. 1, USGS National Hydrography Dataset Best Resolution for Hydrologic Unit 4-2012 (published 20120610), accessed August 2, 2017, at https://www.usgs. gov/core-science-systems/ngp/national-hydrography/accessnational-hydrography-products.

U.S. Geological Survey, 2020, USGS water data for the Nation: U.S. Geological Survey National Water Information System database, accessed February 2020 at https:/doi.org/ 10.5066/F7P55KJN.

University of Alabama, 2017, Contemporary maps of Alabama-Physiographic regions: University of Alabama, Department of Geography, Cartographic Research Lab online database, accessed December 11, 2019, at http://alabamamaps.ua.edu/contemporarymaps/alabama/ physical/index.html.

Voshell, J.R., 2002, A guide to common freshwater invertebrates of North America: Newark, Ohio, McDonald and Woodward Publishing Company, 442 p.
For more information about this publication, contact

Director, Lower Mississippi-Gulf Water Science Center

U.S. Geological Survey

640 Grassmere Park, Suite 100

Nashville, TN 37211

For additional information, visit

https://www.usgs.gov/centers/lmg-water/

Publishing support provided by

Lafayette Publishing Service Center 

